The Geological Society of America

Field Guide 39

2015

\title{
A Laurentian margin back-arc: The Ordovician Wedowee-Emuckfaw-Dahlonega basin
}

\author{
Clinton Barineau* \\ Columbus State University, Department of Earth and Space Sciences, Columbus State University, Columbus, Georgia 31907, USA \\ James F. Tull* \\ Florida State University, Department of Earth Ocean and Atmospheric Science, Tallahassee, Florida 32306-4520, USA \\ Christopher S. Holm-Denoma* \\ U.S. Geological Survey, Central Minerals and Environmental Resources Science Center, Denver, Colorado 80225, USA
}

\begin{abstract}
Independent researchers working in the Talladega belt, Ashland-WedoweeEmuckfaw belt, and Opelika Complex of Alabama, as well as the Dahlonega gold belt and western Inner Piedmont of Alabama, Georgia, and the Carolinas, have mapped stratigraphic sequences unique to each region. Although historically considered distinct terranes of disparate origin, a synthesis of data suggests that each includes lithologic units that formed in an Ordovician back-arc basin (Wedowee-EmuckfawDahlonega basin-WEDB). Rocks in these terranes include varying proportions of metamorphosed mafic and bimodal volcanic rock suites interlayered with deep-water metasedimentary rock sequences. Metavolcanic rocks yield ages that are EarlyMiddle Ordovician (480-460 Ma) and interlayered metasedimentary units are populated with both Grenville and Early-Middle Ordovician detrital zircons. Metamafic rocks display geochemical trends ranging from mid-oceanic-ridge basalt to arc affinity, similar to modern back-arc basalts. The collective data set limits formation of the WEDB to a suprasubduction system built on and adjacent to upper Neoproterozoiclower Paleozoic rocks of the passive Laurentian margin at the trailing edge of Iapetus, specifically in a continental margin back-arc setting. Overwhelmingly, the geologic history of the southern Appalachians, including rocks of the WEDB described here, indicates that the Ordovician Taconic orogeny in the southern Appalachians developed in an accretionary orogenic setting instead of the traditional collisional orogenic setting attributed to subduction of the Laurentian margin beneath an exotic or peri-Laurentian arc. Well-studied Cenozoic accretionary orogens provide excellent analogs for Taconic orogenesis, and an accretionary orogenic model for the southern Appalachian Taconic orogeny can account for aspects of Ordovician tectonics not easily explained through collisional orogenesis.
\end{abstract}

\footnotetext{
*barineau_clinton@columbusstate.edu; jtull@fsu.edu; cholm-denoma@usgs.gov

Barineau, C.I., Tull, J.F., and Holm-Denoma, C.S., 2015, A Laurentian margin back-arc: The Ordovician Wedowee-Emuckfaw-Dahlonega basin, in Holmes, A.E., ed., Diverse Excursions in the Southeast: Paleozoic to Present: Geological Society of America Field Guide 39, p. 21-78, doi:10.1130/2015.0039(02). For permission to copy, contact editing @ geosociety.org. @ 2015 The Geological Society of America. All rights reserved.
} 


\section{GEOLOGIC OVERVIEW}

This guidebook provides a stratigraphic, structural, geochemical, and geochronological framework for six sequences of rock in the Blue Ridge and Piedmont regions of Alabama, Georgia, and the Carolinas. These lithotectonic suites-the western Blue Ridge-equivalent Talladega belt's Hillabee Greenstone, eastern Blue Ridge Ashland-Wedowee-Emuckfaw belt and Dahlonega gold belt, the Brevard fault zone's Jacksons Gap Group, and western Inner Piedmont Opelika Complex and Poor Mountain Formation-have historically been mapped as disparate units with distinct geologic histories and tectonic affinities (Fig. 1). Over the past decade, however, a growing body of evidence (McClellan et al., 2007; Tull et al., 2007, 2012, 2014; Holm-Denoma and Das, 2010) suggests that they share, at least in part, a common tectonic history. In the model presented here, these regions formed, either in whole or part, in an Ordovician back-arc basin that developed on the Laurentian plate seaward of the continental hinge zone on thinned continental, transitional, or oceanic crust (Tull et al., 2014). The model presented here, in which the locus of orogenic activity is on an overriding Laurentian plate due to B-type subduction of Iapetus lithosphere, contrasts with models for initial phases of the Taconic orogeny in the northern and central Appalachians, wherein orogenesis is the result of A-type subduction of the Laurentian plate beneath an exotic or peri-Laurentian arc (Chapple, 1973; Robinson and Hall, 1980; Rowley and Kidd, 1981; Stanley and Ratcliffe, 1985; Karabinos et al., 1998; Waldron and van Staal, 2001; van Staal et al., 2007; Zagorevski et al., 2006). This model has historically been applied along the length of the Laurentian margin and used to explain Ordovician orogenesis in the southern Appalachians (Shanmugam and Lash, 1982; Hatcher, 1987; Higgins et al.,
1988; Drake et al., 1989; Hatcher et al., 2007; McClellan et al., 2007). We provide a stratigraphic overview and geologic history for each of the lithotectonic suites that comprise the WedoweeEmuckfaw-Dahlonega basin (WEDB), with special emphasis on their early Paleozoic history and tectonic setting.

\section{Talladega Belt}

The Talladega belt (Talladega "Slate" belt; Figs. 1 and 2) consists of three Paleozoic units of sedimentary origin, two older and one younger than the WEDB, structurally below an allochthonous Lower-Middle Ordovician bimodal volcanic suite (Fig. 3), all of which were collectively metamorphosed to lower greenschist facies in the Mississippian. On its northwest boundary, the Talladega belt is in the hanging wall of the Talladega-Cartersville fault, which separates it from structurally lower foreland thrust sheets. On its southeast boundary it lies in the footwall of the Hollins Line fault system, separating it from the structurally overlying Ashland-WedoweeEmuckfaw belt (Fig. 2). With the exception of the upper metavolcanic suite (Hillabee Greenstone), rocks of the Talladega belt formed along the outermost passive margin of Laurentia and were not part of the WEDB - although the older two sequences may have been influenced by the far-field effects of Ordovician back-arc rifting. We provide a brief overview of each of the Laurentian shelf units (Kahatchee Mountain Group, Sylacauga Marble Group, and Talladega Group) and tectonically emplaced Hillabee Greenstone. A detailed discussion of the stratigraphy and geologic history of Laurentian shelf units are found in Tull et al. (2012).

\section{Kahatchee Mountain Group}

At the structural and stratigraphic base of the belt, the Kahatchee Mountain Group (Fig. 3) consists of more than $2 \mathrm{~km}$

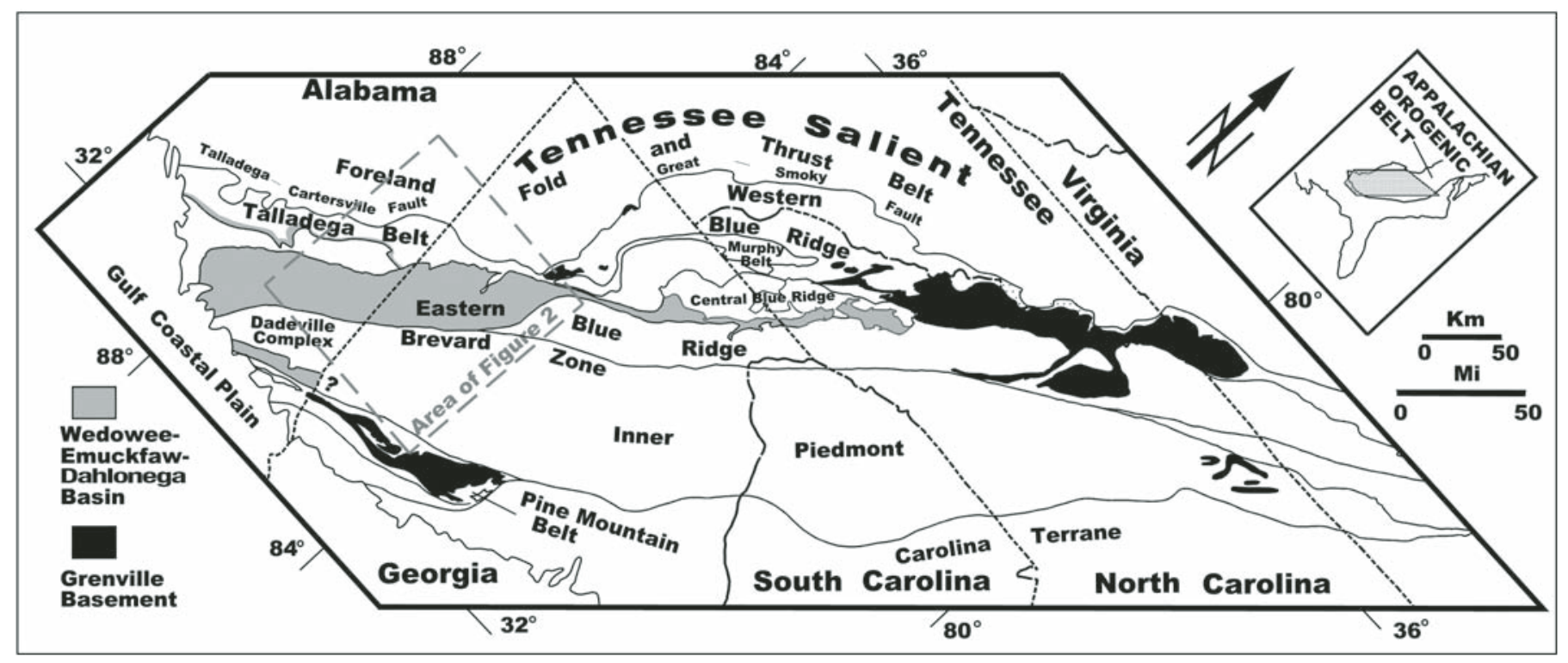

Figure 1. Generalized geologic map of the southern Appalachians showing major terranes. Inset on left depicts area shown in Figure 2. 


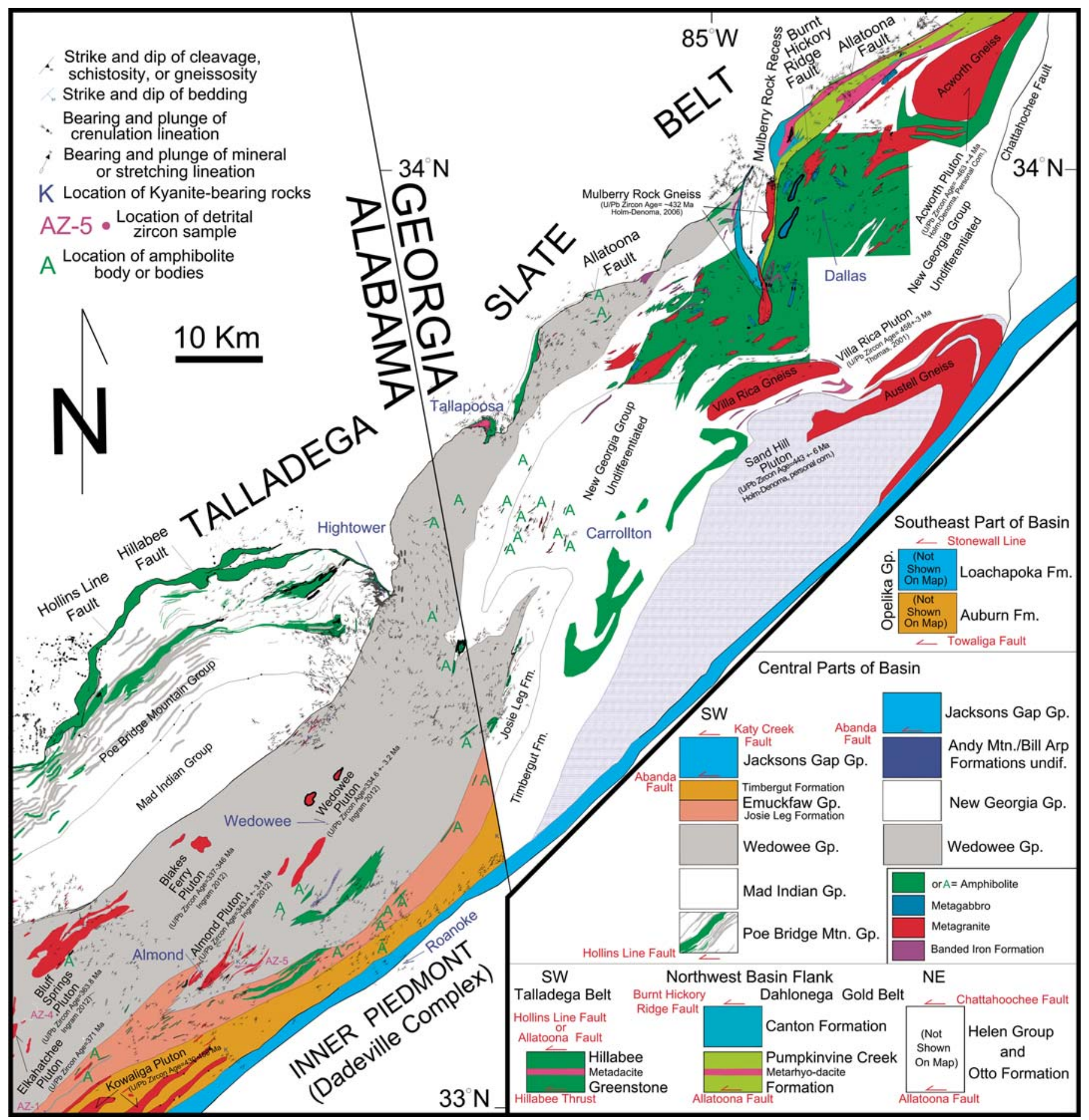

Figure 2. Geologic map of the central WEDB showing correlations between rocks of the eastern Blue Ridge of Alabama and Georgia. Includes map data of George Heuler and EDMAP projects by Adam Aspenwall, Keely Campbell, Hope Cates, and Valerie Smith. 


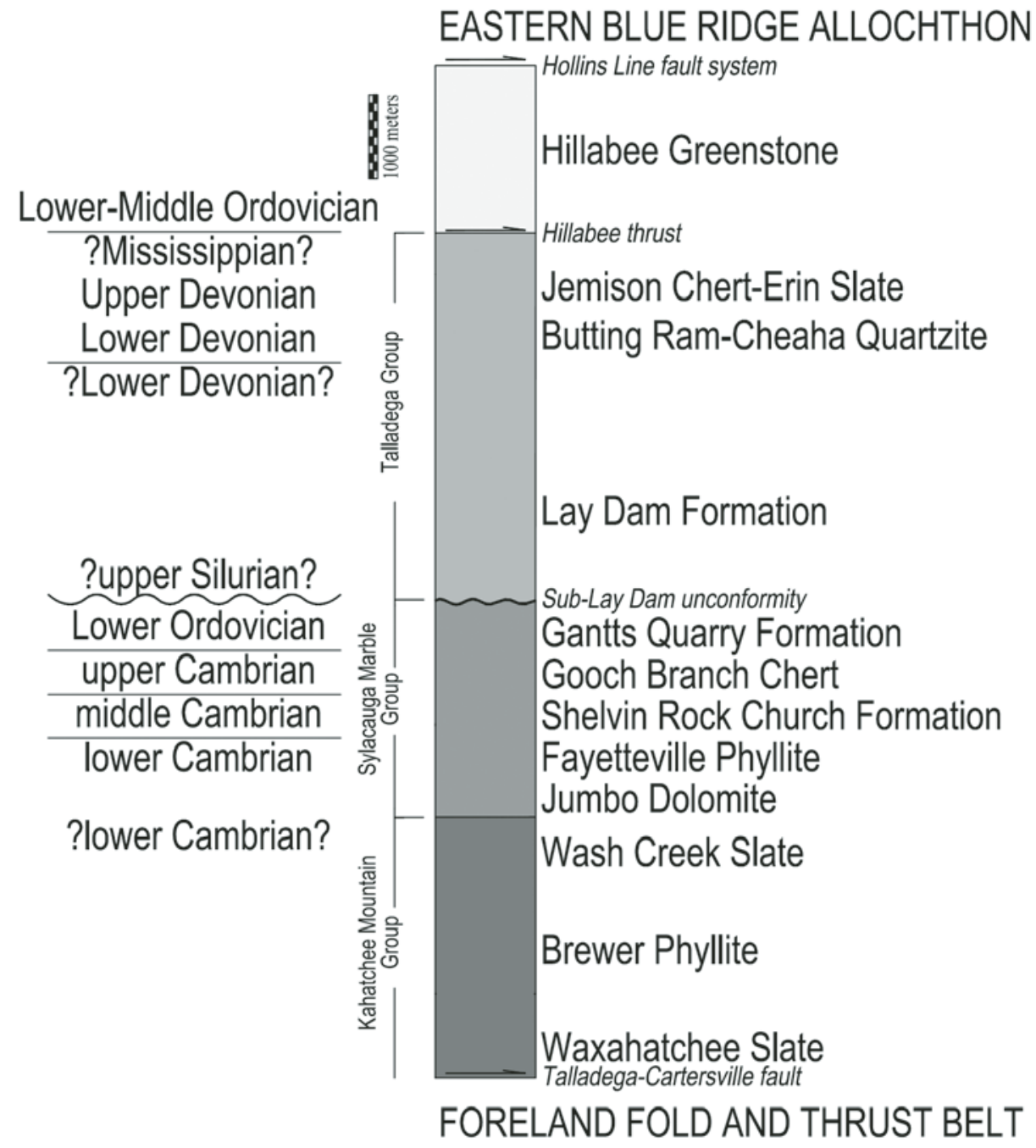

Figure 3. Generalized stratigraphic column for the Talladega belt. of predominantly siliciclastic rocks and is correlated with the Laurentian drift facies, lower Cambrian (time scale herein from Cohen et al., 2013) Chilhowee Group in the foreland (Tull et al., 2010; Tull and Barineau, 2012). From its structural-stratigraphic base above the Talladega-Cartersville fault (Fig. 2), the Kahatchee Mountain Group can be divided into three units in ascending order: the Waxahatchee Slate, Brewer Phyllite, and Wash Creek Slate (Butts, 1940; Tull et al., 2010; Tull and Barineau, 2012). The basal Waxahatchee Slate is dominated by metamorphosed laminated mudstone-siltstone (phyllite) with lesser amounts of fine- to coarse-grained metasandstone (quartzite). In the middle and upper portions, the unit also locally contains calcareous slate, calcarenite, and dolomitic marble (Sawyer Limestone). The overlying Brewer Phyllite consists predominantly of interlayered metamudstone-siltstone with lesser amounts of locally crossbedded quartzite. The uppermost Wash Creek Slate, like the Waxahatchee Slate, is dominated by laminated phyllite with lesser amounts of quartzite, but is locally carbonaceous. At the stratigraphic top, these rocks grade into carbonaceous marbles of the Sylacauga Marble Group. Lithologies of the Kahatchee Mountain Group record two transgressive sequences (Waxahatchee and Wash Creek slates) with an intervening regression (Brewer Phyllite), and developed on the Alabama promontory passive margin of Laurentia during the early Cambrian following the breakup of Rodinia and formation of Iapetus (Tull et al., 2010, 2012). Although no fossils have been found in the Kahatchee Mountain Group, its gradational contact with the overlying, fossiliferous Sylacauga Marble Group constrains its age to early Cambrian or older.

\section{Sylacauga Marble Group}

Structurally and stratigraphically above the Kahatchee Mountain Group, the Sylacauga Marble Group (Fig. 3) consists of more than $2.5 \mathrm{~km}$ of carbonate sequences and subordinate siliciclatic rocks. From oldest to youngest, the unit can be subdivided into five formations: the Jumbo Dolomite, Fayetteville Phyllite, Shelvin Rock Church Formation, Gooch Branch Chert and Gantts Quarry Formation. Transitionally above the Wash 
Creek Slate, the basal Jumbo Dolomite consists of laminated marbles, calcareous phyllite and fossiliferous, massive dolostone in the upper section, which is gradational with the overlying Fayetteville Phyllite. Biotic elements, including oncoids, pellets, algal and/or cryptalgal-coated grains, pelletal micrite, and echinoderm plates, suggest a peri-tidal depositional environment (Tull et al., 1988; Johnson and Tull, 2002; Tull and Barineau, 2012). Archaeocyathids restrict the age (Fig. 4) to early Cambrian (Stage 2, Terreneuvian Series of Cohen et al., 2013), which along with its lithostratigraphic character suggest correlation with the Shady Dolomite in the foreland (Tull et al., 1988; Johnson and Tull, 2002; Tull and Barineau, 2012).
The overlying Fayetteville Phyllite is dominated by metapelite interbedded with subordinate micaceous-arkosic metasandstone. Like the correlative Rome Formation in the foreland, the Fayetteville Phyllite forms a regressive sequence of siliciclastics from the Laurentian craton that prograded across carbonates of the Jumbo Dolomite (Johnson and Tull, 2002; Tull and Barineau, 2012). Gradational with the underlying Fayetteville Phyllite, the Shelvin Rock Church Formation is the thickest sequence of the Sylacauga Marble Group. Consisting of mixed carbonate-siliciclastics (marble-phyllite) in its basal section, the upper portion is dominated by calcitic-dolomitic, laminated marbles-but also contains a crossbedded, fine-grained, arkosic

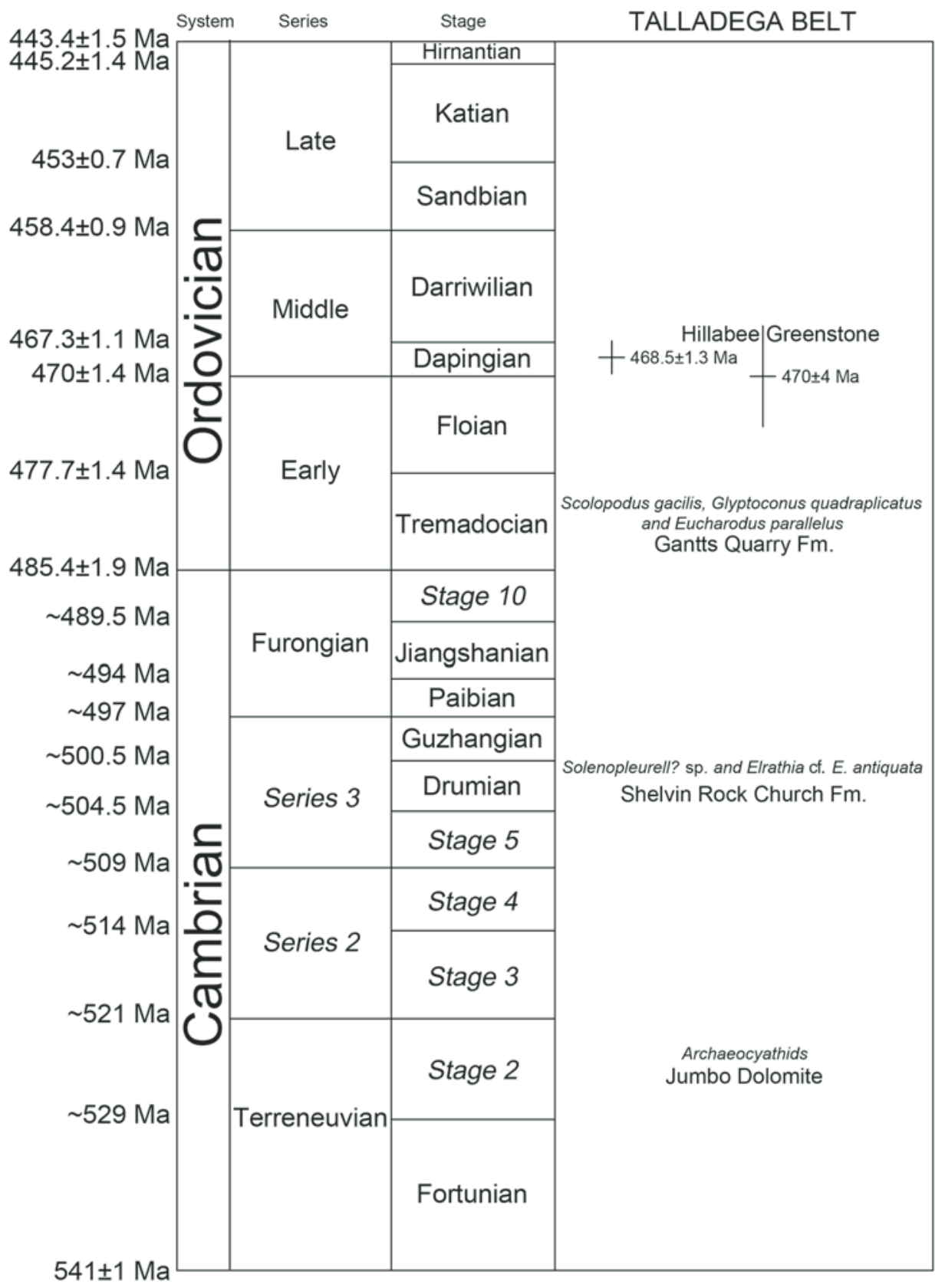

Figure 4. Cambrian and Ordovician time scale of Cohen et al. (2013) showing series, stages, faunal elements of the Sylacauga Marble Group (Johnson and Tull, 2002), and U-Pb crystallization ages for metadacite of the Hillabee Greenstone (McClellan et al., 2007; Tull et al., 2007). 
metasandstone with poorly preserved trilobite trace fossils. These include Solenopleurell? sp. and Elrathia cf. E. antiquata and indicate deposition during Series 3 of the Cambrian (Drumian Stage; David R. Schwimmer, 2014, written commun.). The Shelvin Rock Church Formation is peri-tidal in origin and correlated with the Conasauga Formation of the Alabama foreland (Johnson and Tull, 2002; Tull and Barineau, 2012).

Conformable with the Shelvin Rock Church Formation, the overlying Gooch Branch Chert is interpreted to have formed from silicification of a dolomitic carbonate and contains ooids-pisoids, intraclasts, and possible oncoids, suggestive of a shoaling environment (Johnson and Tull, 2002; Tull and Barineau, 2012). The Gooch Branch Chert is correlated with the Copper Ridge Dolomite of the lower Knox Group. At the top of the Gooch Branch Chert, calcareous phyllites grade into relatively pure marbles of the Gantts Quarry Formation at the stratigraphic-structural top of the Sylacauga Marble Group. Conodonts of three species, Scolopodus gacilis, Glyptoconus quadraplicatus, and Eucharodus parallelus, have been identified in both the Gantts Quarry Formation and Newala Limestone of the foreland Knox Group, suggesting deposition during the Early Ordovician (Tremadocian Stage; Ray Ethington, 2014, written commun) and supporting correlation of these units (Tull et al., 1988; Johnson and Tull, 2002; Tull and Barineau, 2012).

\section{Talladega Group}

The Talladega Group in the stratigraphically and structurally higher portions of the Talladega belt lies above the sub-Lay Dam unconformity, which separates it from the underlying Sylacauga Marble and Kahatchee Mountain Groups. The Talladega Group consists of three formations (Fig. 3) in ascending order: Lay Dam Formation, Butting Ram-Cheaha Quartzite, and Jemison ChertErin Slate. The nature of the contact at the base of the Talladega Group (Lay Dam Formation) has been interpreted as an angular unconformity, fault, or faulted unconformity. We suggest that it is a locally sheared angular unconformity based on stratigraphic and kinematic constraints along the length of this contact.

At the base of the Talladega Group, a more than 2-km-thick clastic wedge of interlayered metaturbidites, arkosic metaconglomerates and olistostromal units, grading both laterally and vertically into monotonous sequences of laminated metapelite (chlorite sericite phyllites), indicates derivation of coarse clastics from proximal basement uplifts and overlying units followed by gradual basin infill with fine-grained sediment (Tull and Telle, 1989; Tull and Barineau, 2012). Sand- to boulder-sized lithic fragments in coarse-grained units commonly consist of marble, metachert, metasandstone-siltstone, and Grenville (ca. $1.1 \mathrm{Ga}$ ) granite and orthogneiss. These were likely derived from basement-cover uplifts to the south-southeast as part of a proximal submarine fan (Telle et al., 1979; Tull and Telle, 1989; Tull and Barineau, 2012). Tull et al. (1988) reported conodont molds from a metapelite within the upper Lay Dam Formation of a post-Ordovician morphotype, most likely of Silurian-Devonian age. Because conformably overlying units of the Butting Ram-
Cheaha Quartzite and Jemison Chert-Erin Slate contain Lower Devonian faunal elements, the age of the Lay Dam is, therefore, restricted to Silurian to Early Devonian. Several lines of evidence suggest the base of the Lay Dam Formation is a locally faulted angular unconformity of Late Silurian to Early Devonian age, including: (1) the unit contains lithic fragments that were derived from underlying rocks of the Sylacauga Marble and Kahatchee Mountain Groups, as well as Grenville basement; (2) it is younger than the underlying upper Sylacauga Marble Group (Gantts Quarry Formation) based on the presence of postOrdovician conodonts and its structural-stratigraphic position beneath Devonian-Mississippian(?) units of the upper Talladega Group; (3) stratigraphy internal to the Lay Dam Formation is parallel to overlying units of the Butting Ram-Cheaha Quartzite, but discordant to strata of the underlying Sylacauga Marble Group; and (4) observations of localized relief up to several meters on this contact and interpreted as paleokarst (Tull, 1985; Tull and Barineau, 2012). Although segments of the sub-Lay Dam unconformity display evidence for localized shearing (Hatcher, 2008), other sections exhibit evidence for abundant flattening strain, but lack shear fabrics and a strain gradient approaching the contact-all inconsistent with interpretations of the basal Lay Dam Formation as major fault (Woodall and Barineau, 2010; Tull and Barineau, 2012; Barineau et al., 2012). Instead, the presence of locally sheared sections of the sub-Lay Dam unconformity suggests that this boundary may have been exploited as a mechanical weakness, especially in regions where a significant ductility contrast exists between marbles of the Gantts Quarry Formation and siliciclastic units of the lower Lay Dam Formation (Woodall and Barineau, 2010; Barineau et al., 2012).

At the stratigraphic-structural top of the Lay Dam Formation, phyllite and coarse-grained arkosic metaconglomerate grade into mature quartz sands and gravels of the Butting Ram-Cheaha Quartzite. These predominantly metasandstone sequences represent stabilization of the Lay Dam basin and significant reworking of siliciclastics in a shallow, near-shore marine environment (Carter, 1985; Tull and Barineau, 2012). Faunal elements, of the Butting Ram-Cheaha Quartzite, including bryozoans, brachiopods, gastropods and horn corals, restrict its depositional age to Early Devonian (Carrington, 1973). In the southwestern Talladega belt, units of the upper Butting Ram Quartzite transition into metachert and subordinate phyllite-metasandstone (Jemison Chert) and suggest development of a starved basin sequence with limited siliciclastic input above the quartz-rich, near-shore environment of the underlying sands and gravels (Tull, 2002). In the same stratigraphic position, the Cheaha Quartzite of the central and northeastern sections of the Talladega belt is gradational with variably graphitic chlorite sericite phyllites of the overlying Erin Slate, a facies equivalent of the Jemison Chert (Tull, 2002; Tull and Barineau, 2012). Age constraints on the Jemison Chert-Erin Slate include abundant marine invertebrates of Early-Middle Devonian age (Butts, 1926; Carrington, 1973; Sutley, 1977; Tull et al., 1988) in the lower and middle portions of the Jemison Chert and a rare leaf petiole (Periastron reticulatum) of an aquatic or 
semi-aquatic plant of unknown taxonomic affinity (Beck, 1978) from the uppermost Erin Slate (Gastaldo, 1995). Found only in France, Germany, and North America, Periastron is generally assigned to rocks of Mississippian age, but may have an age range inclusive of the Middle-Late Devonian (Beck, 1978; Tull and Barineau, 2012).

\section{Hillabee Greenstone}

Structurally above the Talladega Group, a $>2.6-\mathrm{km}$-thick bimodal metavolcanic suite - the Hillabee Greenstone — consists predominantly of phyllitic and massive greenstones interlayered with subordinate quartz metadacite-rhyodacite. The Hillabee Greenstone can be mapped (Fig. 2) from beneath the Coastal Plain unconformity at the southwestern end of the Talladega belt near Clanton, Alabama, to western Georgia along much of the strike length of the Talladega belt $(>200 \mathrm{~km})$. Greenstone lithologies contain chlorite, albite, epidote-clinozoisite-zoisite, and actinolite mineral assemblages, in addition to relict plagioclase and clinopyroxene crystals, and exhibit ophitic and porphyritic textures indicative of their igneous origin. Ellipsoidal pods of epidosite have hypidiomorphic textures interpreted as volcanic ejecta and suggest both effusive and explosive mafic volcanism (Tull and Stow, 1980; Tull and Barineau, 2012). In some areas (e.g., Pyriton, Alabama), greenstones include laterally continuous $(>10 \mathrm{~km}$ ) stratabound massive sulfide deposits (e.g., pyrite) interpreted as syn-volcanogenic exhalatives (Tull et al., 1998). In addition to these massive sulfides, porphyritic, quartz metadacites composed of fine-grained quartz, sericite, epidote, actinolite with phenocrysts of hornblende, quartz, and plagioclase form an internal stratigraphy ranging from localized, relatively small units to thick ( $>150 \mathrm{~m})$, laterally extensive (>20 km along strike) layers (Tull and Stow, 1980; Tull et al., 2007, 2012, 2014). Metadacite bodies sometimes incorporate blocks of mafic greenstone and metamorphosed pumice fragments, which coupled with their size, are indicative of large ash flow and/or fall eruptions from a proximal volcanic source (Tull et al., 1998, 2007; Tull and Barineau, 2012).

Geochemistry of the Hillabee Greenstone has revealed important insights into the age, petrogenesis, and tectonic setting of this bimodal metavolcanic suite. Major element analyses indicate that mafic protoliths for greenstone lithologies were low-K tholeiites, whereas felsic protoliths were calc-alkaline. Mafic lithologies have silica compositions $\left(45 \%-54 \% \quad \mathrm{SiO}_{2}\right)$ typical of basalt and basaltic andesites, and some exhibit high $\mathrm{Na}_{2} \mathrm{O}$ and low $\mathrm{CaO}-\mathrm{MgO}$ concentrations typical of spillites (Tull and Stow, 1980). Silicic rocks, in contrast, are more typical of metadacites and rhyodacites $\left(65 \%-71 \% \mathrm{SiO}_{2}\right)$ with an obvious silica gap (14\%) between mafic and silicic components (Tull and Stow, 1980; Tull et al., 2007, 2012, 2014). This silica gap and the knife-sharp boundaries between greenstones and metadacites led Tull and Stow (1980) to argue against generation of the metadacites via differentiation of the magma body forming the mafic lithologies. This premise is supported by trace element analysis of zircon from metadacite that yields negative $\mathrm{eHf}$ values ( -4 to
-8) and 1.1-1.0 Ga depleted mantle model ages suggestive of partial melting of Grenville-aged continental crust (Tull et al., 2007, 2012, 2014).

The age of the Hillabee Greenstone had been a subject of significant controversy until the development of analytical techniques capable of single-grain U-Pb isotopic analysis (Fig. 4). Relative concordance between internal lithologies of the Hillabee Greenstone (e.g., metadacites and massive sulfide zones) and the underlying Talladega Group led workers (e.g., Prouty, 1923; Neathery, 1973; Tull, 1978; Tull et al., 1998; Tull and Stow, 1980) to suggest that the Hillabee postdated the underlying metasedimentary units and was, therefore, Middle Devonian or younger. In contrast, multigrain zircon analyses reported by Russell (1978) yielded slightly discordant U-Pb ages between 462 and $444 \mathrm{Ma}$. Subsequent analysis of individual zircons via high resolution-high sensitivity ion microprobe confirmed the older ages, constraining crystallization of Hillabee metadacites between 470 and $468 \mathrm{Ma}$ (earliest Middle Ordovician, Dapingian Stage). This requires the Hillabee to be faulted onto Talladega Group metasedimentary rocks of the Laurentian shelf prior to lower greenschist facies metamorphism (McClellan and Miller, 2000; McClellan et al., 2005, 2007; Tull et al., 2007). The collective stratigraphic and geochronologic data indicate that final emplacement of the Hillabee Greenstone along the Hillabee thrust occurred after deposition of the youngest unit in the Talladega Group (Jemison Chert-Erin Slate, Middle Devonian to lower Mississippian?), but before Middle-Late Mississippian $\left({ }^{40} \mathrm{Ar} /{ }^{\beta 9} \mathrm{Ar}\right.$, 334-320 Ma) metamorphism (McClellan et al., 2007) of the units (Tull et al., 2007, 2012). Structural constraints indicate the Hillabee Greenstone was emplaced along the Hillabee thrust with a flat-onflat geometry (Fig. 4) over the entire strike length of the Talladega belt, suggesting little or no deformation before or during emplacement. This geometry makes it highly improbable that the Hillabee Greenstone was transported across any significant fault ramps, which would have resulted in fault-bend folding, and suggests it occupied a palinspastic location slightly outboard and proximal to the Laurentian shelf during the Middle Ordovician (Barineau, 2009; Tull et al., 2007, 2012, 2014).

\section{Ashland-Wedowee-Emuckfaw Belt}

Along the southeastern margin of the Talladega belt (Fig. 2), the Hollins Line fault system separates lower greenschist facies rocks of the Hillabee Greenstone and upper Talladega Group from middle-upper amphibolite facies rocks of the Ashland-WedoweeEmuckfaw belt (eastern Blue Ridge of Alabama). This major thrust system has a footwall duplex geometry that imbricates lithologies of the Hillabee Greenstone and upper Talladega Group between the roof and floor thrusts. Structural constraints indicate it is a post-metamorphic dextral, transpressional fault of probable Permian age that formed in response to crustal shortening associated with the Alleghanian orogeny (Tull et al., 2007, 2012; Barineau, 2009; Tull and Barineau, 2012). At the southeastern limit of the Ashland-Wedowee-Emuckfaw belt, the Abanda fault (Brevard fault zone) separates the Ashland-Wedowee-Emuckfaw 
belt from the Jacksons Gap Group of the Brevard fault zone. Two additional faults important to the geologic history of the eastern Blue Ridge in Alabama are internal to the Ashland-WedoweeEmuckfaw belt: the Goodwater-Enitachopco and Alexander City faults (Figs. 2 and 5).

\section{Goodwater-Enitachopco and Alexander City Faults}

Southeast of the Hollins Line fault system, the GoodwaterEnitachopco fault (Figs. 2 and 5) is the boundary between the upper Ashland Supergroup and lower Wedowee Group over much of its strike length. Southwest of Goodwater, Alabama, however, the contact appears to be a conformable polydeformed stratigraphic boundary (Allison, 1992), suggesting the fault tips out in this region. Displacement along the Goodwater-Enitachopco fault gradually increases to the northeast and cuts east-southeasttrending, map-scale late Paleozoic cross-folds affecting the Hollins Line fault, Talladega-Cartersville fault, Talladega belt, and stratigraphy of the eastern foreland. The northeastern extent of this fault is unclear, but has been suggested (Tull, 1978, 2011) to be the same structure identified as the Allatoona fault in eastern Alabama-western Georgia, where it truncates the Hollins Line fault system near Hightower, Alabama. Although historically suggested to be a late brittle fault with mostly normal slip (Tull et al., 1985; Drummond, 1986; Allison, 1992; Drummond et al., 1994, 1997; Tull, 2011), Steltenpohl et al. (2013) suggest it has an earlier right-slip, mylonitic foliation, coplanar with the dominant contractional foliation, overprinted by normal and obliquedextral shear zones that truncate the earlier foliations. They suggest both shear sets resulted from two phases of shearing and

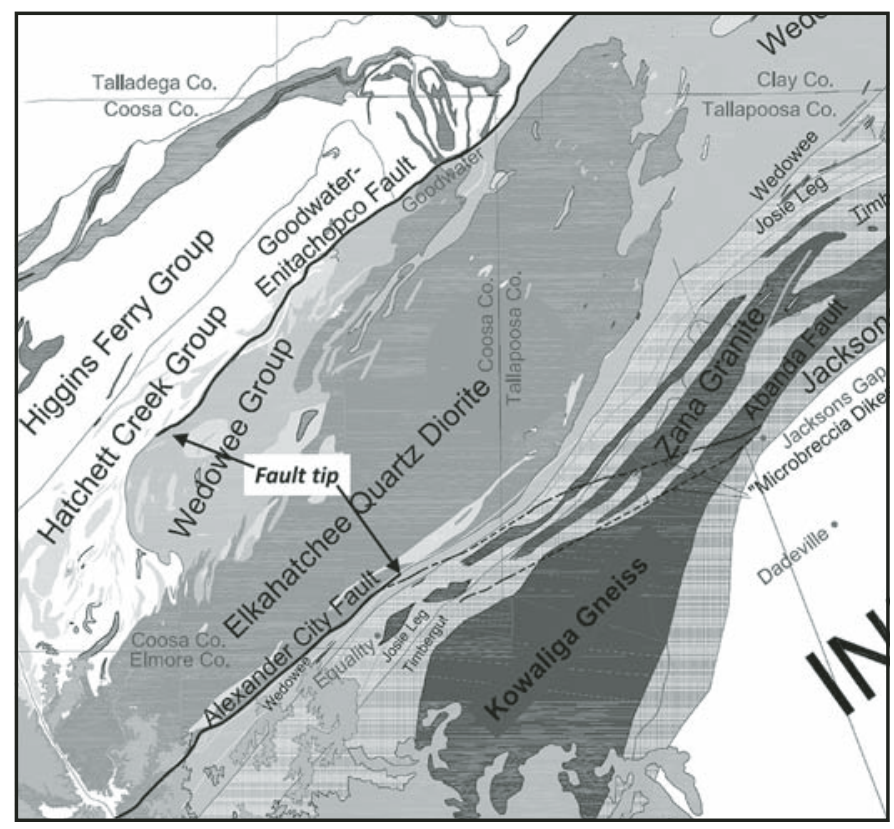

Figure 5. Geologic map of a portion of the Ashland-WedoweeEmuckfaw belt showing the Goodwater-Enitachopco and Alexander City faults (after Tull, 2011). developed under relatively high temperature $\left(450-600^{\circ} \mathrm{C}\right)$ ductile conditions on the basis of quartz and feldspar deformational microstructures (Steltenpohl et al., 2013).

The location of the Alexander City fault is detailed in Tull and Campbell (2012), but has traditionally been mapped on the southeastern margin of the Upper Devonian Elkahatchee batholith, separating it along most of its southeastern contact from metasedimentary rocks of the Ordovician Wedowee Group. On its northwest, north, and northeast flanks, the batholith exhibits intrusive contacts with the Wedowee Group. Southwest of Alexander City, however, the contact is nearly linear and traces northeast more than $30 \mathrm{~km}$ from Jordan Lake, where it emerges from beneath Cretaceous sedimentary rocks of the Gulf Coastal Plain. It is in this region that this contact is clearly a fault. Units on either side of the fault in this region are middle-upper amphibolite facies and share a common metamorphic fabric. We suggest that the fault tips out southwest of Alexander City (Fig. 5) along the Elkahatchee-Wedowee contact (Tull, 2011; Harstad and Barineau, 2014), while in other interpretations it continues to the northeast, tipping out in stratigraphy of the Wedowee and Emuckfaw Groups or continuing to the Georgia state line (e.g., Bieler and Deininger, 1987; Osborne et al., 1988; Drummond et al., 1997; Steltenpohl et al., 2013). Shear sense indicators along the southeastern margin of the Elkahatchee batholith suggest oblique normal dextral shear that produced mylonitic fabrics in orthogneiss lithologies and S-C foliations in the structurally overlying Wedowee Group metapelites, in addition to a younger, cataclastic phase of shearing (Drummond et al., 1994) consistent with interpretations by Steltenpohl et al. (2013).

Precise time constraints on the development of shearing are limited. Steltenpohl et al. $(2005,2013)$ suggest that a ca. $327 \mathrm{Ma}$ ${ }^{40} \mathrm{Ar} /{ }^{39} \mathrm{Ar}$ muscovite age from a sheared pegmatite adjacent to the Goodwater-Enitachopco fault marks the age of right-slip shearing during initial movement along this fault. However, the linear trace of the fault and the fact that it cuts cross-folds of both the Hollins Line and Talladega-Cartersville thrust faults, Pennsylvanian strata in the foreland, and stratigraphy of the Ashland Supergroup make it clear that the current trace of the fault developed after metamorphism of the Talladega and Ashland-Wedowee-Emuckfaw belts, after deposition of Pennsylvanian stratigraphy in the foreland, and after emplacement of the Ashland-Wedowee-Emuckfaw belt on top of the Talladega belt (Tull, 1978, 2011; Tull et al., 1985; Barineau, 2009; Barineau and Tull, 2012). Additionally, because the Hollins Line fault system could have been active as late as the Permian during Alleghanian orogenesis, development of the current trace of the Goodwater-Enitachopco fault probably postdates the muscovite cooling ages reported by Steltenpohl et al. (2013) by 30-50 m.y. A ca. 327 Ma muscovite cooling age, however, is consistent with crystallization of the syn-kinematic Wedowee pluton, which yielded U-Pb ages of $334.6 \pm 3.2 \mathrm{Ma}$ (Ingram, 2012). ${ }^{40} \mathrm{Ar} /{ }^{39} \mathrm{Ar}$ hornblende cooling ages (333.8 \pm 1.7 and $329.6 \pm 1.1 \mathrm{Ma}$ ) from the Mitchell Dam Amphibolite also denote a thermal event during this interval (Steltenpohl et al., 2005). This suggests that the white mica ${ }^{40} \mathrm{Ar} /{ }^{39} \mathrm{Ar}$ ages (Steltenpohl et al., 
2005, 2013) from a sheared pegmatite adjacent to the GoodwaterEnitachopco fault represent cooling ages associated with uplift of the Ashland-Wedowee-Emuckfaw belt, and not movement of the fault itself (Tull et al., 2007; Barineau, 2009; Tull, 2011). The collective data set strongly supports that this fault formed either during relaxation and collapse of the orogenic hinterland at the end of the Alleghanian orogeny (Tull et al., 1985), or during Mesozoic rifting (Tull, 1978, 2011; Tull et al., 1985; Allison, 1992; Drummond et al., 1997).

Steltenpohl et al. (2013) attempted to constrain the age of right-slip shearing along the Alexander City fault via U-Pb dating of a trondhjemitic dike in the Elkahatchee batholith, which they interpret as developing on the "shoulder" of the Alexander City fault during ductile, right-slip shearing. Here, along Elkahatchee Creek, the batholith was intruded by a sequence of felsic dikes and pegmatites, which are overprinted by the regional metamorphic fabric to various degrees (Moore et al., 1987). The cuspate-lobate contacts between these dikes and their host (figure 4 in Moore et al., 1987), however, indicate that the batholith was not entirely crystallized at the time of dike intrusion. Using the upper discordia intercept age for five zircon analyses that formed a linear array, Steltenpohl et al. (2013) assigned an age of 369.4 \pm $4 \mathrm{Ma}$ to one of these trondhjemitic dikes cutting a dextral shear zone within the batholith, bracketing the development of the shear zone using the age of the pre-kinematic Elkahatchee batholith (reported therein as 388-370 Ma) and ca. 369 Ma trondhjemitic dike. They then go on to suggest that the Alexander City fault southwest of this location may be associated with ca. $375 \mathrm{Ma}$ (Late Devonian) dextral shear zones (e.g., Burnsville fault) in the Blue Ridge of western North Carolina (Trupe et al., 2003).

Two issues, however, significantly complicate this interpretation. First, the trondhjemitic dike they analyzed is $\sim 4 \mathrm{~km}$ northwest of the southeastern margin of the batholith and the trace of the Alexander City fault, calling into question its relationship to mylonitic fabrics on the southeast margin of the Elkahatchee batholith. Additionally, a $371 \pm 7$ Ma age for the Elkahatchee batholith from the same outcrop (Barineau, 2009; Tull et al., 2009) containing the 369.4 \pm 4 Ma trondhjemitic dike reported in Steltenpohl et al. (2013) suggests that this dike was emplaced shortly after intrusion of the main granodioritic body of the batholith. A ca. 371 Ma age for the Elkahatchee is supported by three additional zircon analyses from different locations within the Elkahatchee batholith, including $370 \pm 6 \mathrm{Ma}$ (grains $<1 \%$ discordant), $372 \pm 7 \mathrm{Ma}$ (grains $<1 \%$ discordant), and $371 \pm 3.5$ Ma ages (P.A. Mueller, 2014, written commun.). A fourth Elkahatchee sample yielding a $355 \pm 6.3$ Ma age (grains $<2 \%$ discordant) contrasts with these ca. $370 \mathrm{Ma}$ ages and may suggest the Elkahatchee is a temporally diverse pluton (P.A. Mueller, 2014, written commun.). Regardless, crystallization of the Elkahatchee batholith during the same relatively narrow time frame as the age reported for the shear zone-cutting trondhjemitic dike indicates that dextral shear recorded at this location $(\sim 4 \mathrm{~km}$ northwest of the Alexander City fault) is the result of shearing under magmatic or slightly, post-magmatic conditions. Plutons exhibiting complex magmatic and post-magmatic deformation features are reported from the Pacific Northwest (Miller and Paterson, 1994), and it is not unreasonable to assume the same may have occurred here. Additionally, because dynamothermal middle to upper amphibolite facies metamorphism in the Ashland-Wedowee-Emuckfaw belt did not peak until ca. $335 \mathrm{Ma}$ or younger based on the age of the youngest syn-kinematic pluton in the Alabama eastern Blue Ridge (Wedowee pluton; Ingram, 2012), it is also possible that the $369.4 \pm 4$ Ma discordia age reported for the shear zone-cutting trondhjemitic dike within the Elkahatchee batholith has an anomalously old age due to incorporation of xenocrystic components from the Elkahatchee batholith.

Although Steltenpohl et al. (2013) suggest a polyphase history of shearing along the Alexander City fault, it is unlikely that the brittle Alexander City fault overprints a regionally significant Devonian shear zone. Additionally, it is difficult to conceive how the proposed ca. 370 Ma regionally developed shear zone could maintain the relatively linear trace suggested by Steltenpohl et al. (2013, their figure 2) considering that peak metamorphism and deformation postdate the proposed shear zone by $>30 \mathrm{~m}$.y. and resulted in development of isoclinal structures affecting prekinematic elements of the Ashland-Wedowee-Emuckfaw belt. We suggest that mylonitic foliations observed along the southeastern margin of the Elkahatchee batholith, in proximity to the much younger Alexander City fault, are probably the result of shear strain along the margins of the batholith due to the mechanical contrast between coarse-grained granodioritic phases of the Elkahatchee batholith and graphitic schists (metapelites) of the overlying Wedowee Group. In other regions of this belt, we have observed similar mylonitic ductile shear zones along the margins of the Zana orthogneiss where it is in contact with schist of the Emuckfaw Group. In these exposures, mylonitic foliations are concentrated along the margins of the batholith over a distance of $<25 \mathrm{~m}$ and are not generally present within the interior. We adopt the model proposed by Tull (2011) and Tull and Campbell (2012) wherein the Goodwater-Enitachopco and Alexander City faults (Fig. 2) are en echelon left, rotational extensional faults connected across a transfer zone from the tip of the Alexander City fault (southwest of Alexander City, Alabama) to the tip of the Goodwater-Enitachopco fault (southwest of Goodwater, Alabama). The relatively linear trace and predominantly normal-slip sense of shear along each fault reflects either post-orogenic collapse following the Alleghanian orogeny or far-field extensional stresses associated with Mesozoic rifting and Cenozoic uplift. Observed dextral shear indicators associated with mylonitic foliations in the Ashland-Wedowee-Emuckfaw belt are most likely the result of syn-kinematic shear accompanying broad-scale deformation during the Mississippian.

\section{Ashland Supergroup}

At the structural and stratigraphic base of the AshlandWedowee-Emuckfaw belt, stratigraphy of the Ashland Supergroup (Fig. 6) can be mapped both northwest and southeast of the Millerville antiform (Tull, 1978). Southwest of the antiform, the 


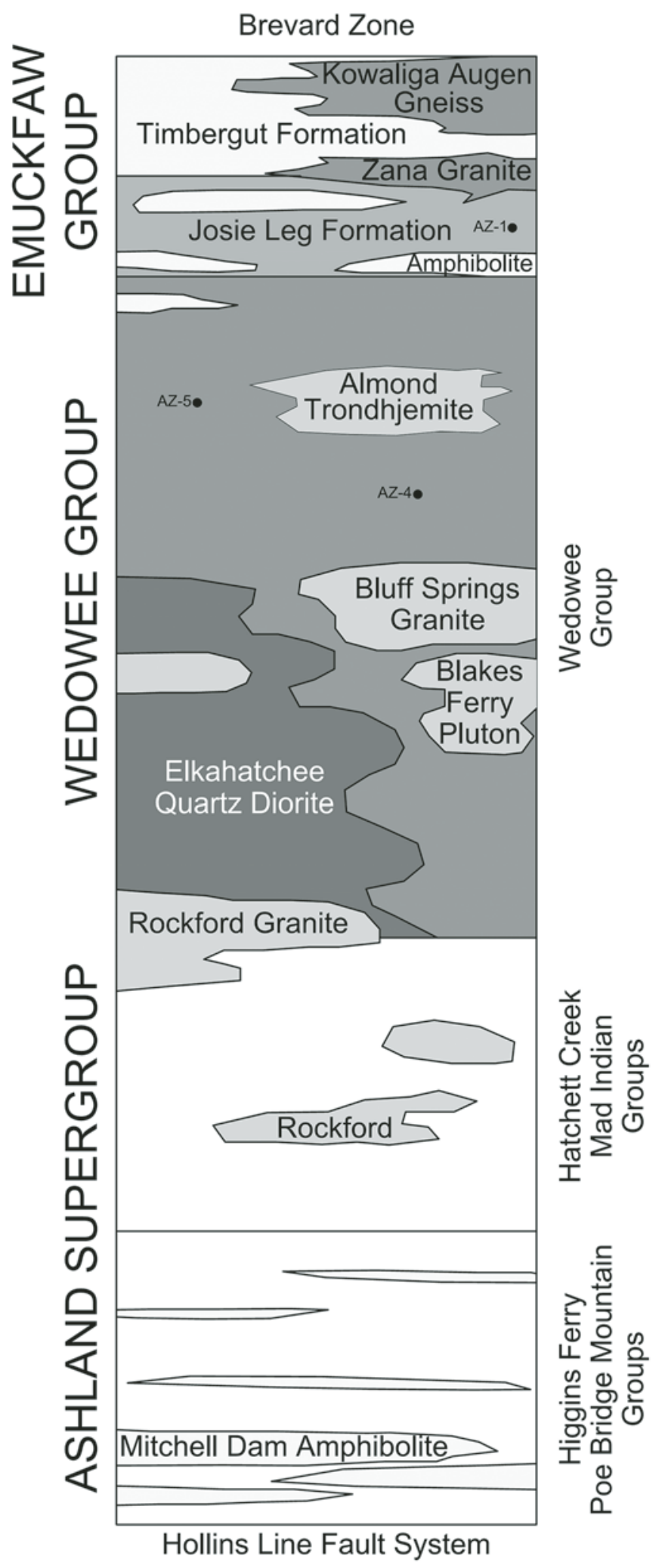

Figure 6. Generalized stratigraphic column for the AshlandWedowee-Emuckfaw belt showing WEDB units, younger intrusives, and detrital zircon locales.
Higgins Ferry Group lies structurally and stratigraphically below the Hatchett Creek Group. Northeast of the Millerville antiform, the Poe Bridge Mountain Group lies structurally and stratigraphically below the Mad Indian Group (Neathery, 1975; Tull, 1978). The correlative Higgins Ferry-Poe Bridge Mountain Groups at the base of the Ashland Supergroup are dominated by biotitemuscovite schist (including rare vanadium-bearing roscoelite mica) of varying garnet, feldspar, quartz, and graphite content, in addition to subordinate fine-grained paragneiss and graphitic quartzite. Metapelitic units locally include staurolite, kyanite, and sillimanite, which coupled with the presence of pegmatite (muscovite, biotite, plagioclase, k-feldspar, and quartz) and migmatitic units, support middle-upper amphibolite facies conditions of metamorphism (as much as $775{ }^{\circ} \mathrm{C}, 8.6 \mathrm{~kb}$; Allison and Morisani, 2002). In addition to these siliciclastic units, the Higgins Ferry-Poe Bridge Mountain Group also contains distinctive garnetiferous graphitic quartzite and discrete, isolated lenses as well as laterally extensive ( $>30 \mathrm{~km}$ in length), thick (>100 m) bodies of orthoamphibolite (e.g., Mitchell Dam and Ketchapedrakee Amphibolites). The geochemical character, presence of relict orthopyroxene crystals in hornblende-rich, Ca-plagioclasebearing amphibolites, in addition to the concordant nature of the amphibolite bodies with adjacent and interlayered siliciclastic units, suggest that the protoliths of these rocks were mafic tholeiitic magmas and were emplaced as sills and/or flows during and/or following deposition of the sedimentary sequences (Stow et al., 1984). Trace element analysis of orthoamphibolites suggests emplacement in a continental rift setting, consistent with the overall lithologic character of the lower Ashland Supergroup (Stow et al., 1984; Tull et al., 2014).

Structurally and stratigraphically above the Higgins FerryPoe Bridge Mountain Group, the correlative Hatchett Creek and Mad Indian Groups (Fig. 6) southwest and northeast of the Millerville antiform, respectively, are dominated by muscovitebiotite schists of varying feldspar, quartz, and garnet content, but also contain subordinate fine-grained garnet biotite paragneiss, micaceous quartzite, calc-silicate, and graphitic schist (Tull, 1978; Drummond et al., 1988; Allison, 1992). Like the basal units of the Ashland Supergroup, these upper units contain migmatitic gneiss, are intruded by pegmatitic dikes, and schist locally contains both kyanite and sillimanite. The contact between the upper and lower Ashland Supergroup units is gradational, and protoliths for rocks of the Ashland Supergroup are primarily pelitic units interlayered with subordinate graywacke and mafic flows and/or sills. Alternating layers of metapelite (schist) and metagraywacke (feldspathic schist-paragneiss) are suggestive of turbidite deposits, which coupled with the presence of calcsilicate and orthoamphibolite with geochemical characteristics resembling those of within-plate basalts (Tull et al., 2012), indicate formation of the lower Ashland Supergroup in a slope-rise setting along a rifted continental margin (Tull, 1978; Thomas et al., 1980; Drummond et al., 1988; Allison, 1992; Tull et al., 2012, 2014). $\mathrm{T}_{\text {CHUR }}$ ages between 1055 and 964 Ma from metasedimentary units within the Ashland Supergroup suggest derivation of 
sediment from a Grenvillian source (Das, 2006). This, coupled with its lithologic character and current structural position above Paleozoic Laurentian shelf stratigraphy (Talladega belt), make the Ashland Supergroup the best candidate in Alabama for the Neoproterozoic-lowest Paleozoic Laurentian slope-rise prism (Drummond et al., 1988; Allison, 1992; Tull et al., 2007, 2012, 2014). The Ashland Supergroup is confined entirely to the Alabama portion of the eastern Blue Ridge, being truncated immediately west of the Georgia state line near Hightower, Alabama (Fig. 2). Here, the Goodwater-Enitachopco or Allatoona fault at the structural top of the Ashland Supergroup intersects the roof thrust of the Hollins Line fault at the base of the Ashland Supergroup and places the Wedowee Group against the Talladega belt northeast of this locale.

\section{Wedowee Group}

Rocks of the Wedowee Group (Fig. 6) lie stratigraphically and structurally above those of the Ashland Supergroup, but are separated from the Ashland across much of the Alabama eastern Blue Ridge by the Goodwater-Enitachopco or Allatoona faults. However, southwest of Goodwater, where the GoodwaterEnitachopco fault ends (Fig. 5), the boundary between the two units is a polydeformed stratigraphic contact (Allison, 1992). In regions southwest of this fault tip, the Wedowee Group (Adams, 1926; Neathery and Reynolds, 1973) contact is gradationally above the underlying Hatchett Creek Group (Allison, 1992). Rocks of the Wedowee Group are dominated by locally carbonaceous metapelitic units (variably garnetiferous graphitic schists) interlayered with less common quartzites and thin layers of highly feldspathic schist and/or fine-grained biotite gneiss interpreted as metagraywacke (Neathery, 1975; Allison, 1992). Accessory minerals include tourmaline, staurolite, kyanite, and sillimanite. The Wedowee Group has been subdivided (Neathery, 1975; Drummond, 1986; Allison, 1992) into the graphite-poor Hackneyville Schist and graphite-rich Cragford Phyllite. In many areas, graphite-rich schists of the Cragford are phyllonitic and interlayered with thin sequences of metagraywacke. Rocks of the Hackneyville Schist are, in comparison, less graphitic.

Detrital zircons from a metasandstone and metagraywacke in the middle and upper Wedowee Group (Figs. 2 and 6) yielded $\mathrm{U}-\mathrm{Pb}$ ages between ca. $1800 \mathrm{Ma}$ and ca. $460 \mathrm{Ma}$ (Fig. 7, sample locations-Fig. 2). The majority of the analyses in two samples have a population peak of ca. $1000 \mathrm{Ma}$, a typical late Grenville zircon age assemblage. Importantly, both samples have a small age peak of ca. 460 Ma. Sample AZ-5 has five grains out of 56 ( $<15 \%$ discordant) that define the ca. 460 Ma population (Tull et al., 2014), while sample AZ-4 has three grains out of $85(<15 \%$ discordant) at ca. $460 \mathrm{Ma}$ ). We suggest a Middle Ordovician as well as a Mesoproterozoic (Grenville) source for at least some of the Wedowee sediment (Tull et al., 2014). The presence of Middle Ordovician detrital zircons is significant in that it suggests proximity to Middle Ordovician igneous units of this predominantly sedimentary basin. Units of this age in the region include metavolcanic rocks of the Galts Ferry Gneiss and along- strike equivalents (e.g., Barlow Gneiss) in the Pumpkinvine Creek Formation at the juncture between the Ashland-WedoweeEmuckfaw and Dahlonega gold belts in northwestern Georgia (Holm-Denoma and Das, 2010; Tull et al., 2014). Correlation of units in Alabama, including the Wedowee Group, with strata of the Dahlonega gold belt indicates that volcanic protoliths of orthogneiss-orthoamphibolites of the Pumpkinvine Creek Formation were erupting during deposition of Wedowee Group sedimentary protoliths (Fig. 8) within a common basin (Tull et al., 2014). Middle Ordovician zircons could have been derived from local volcanic sequences that were reworked, or units that have yet to be identified and/or exposed in the Ashland-WedoweeEmuckfaw belt of Alabama. In either case, although ca. $460 \mathrm{Ma}$ zircons from the Wedowee Group provide a maximum depositional age for this unit, we interpret metasedimentary units of the Wedowee Group as Early-Middle Ordovician in age due to along-strike correlations with metavolcanic sequences in the Dahlonega gold belt of Georgia.

\section{Emuckfaw Group}

The Emuckfaw Group (Heard Group of Bentley and Neathery, 1970) in Alabama (Fig. 6) consists of a sequence of variably graphitic-garnetiferous two-mica schist interlayered with less common fine-grained variably garnetiferous, biotite paragneiss (metagraywacke), and micaceous quartzite, in addition to orthoamphibolite (e.g., Beaver Dam Amphibolite in southwestern Randolph County). The Kowaliga Gneiss (Bentley and Neathery, 1970; Bieler and Deininger, 1987), a pre-kinematic pluton intruding the Emuckfaw Group (Fig. 2) has been assigned a tentative age between ca. $430 \mathrm{Ma}$ (Tull et al., 2012) and ca. $450 \mathrm{Ma}$ (P.A. Mueller, 2014, personal commun.), providing an upper age constraint on deposition of both the Emuckfaw and Wedowee Groups (Fig. 8). A number of workers have proposed internal subdivisions for the Emuckfaw Group at different intervals along strike from Alabama to Georgia. Bentley and Neathery (1970) divided the Emuckfaw (Heard Group) in Georgia into a lower Roopville, middle Glenloch, and upper Centralhatchee Formation consisting of interlayered sequences of variably garnetiferous, feldspathic, and graphitic two-mica schist and fine-grained paragneiss. Subsequent workers (e.g., McConnell and Abrams, 1984; German, 1989) assigned equivalent rocks to the "western belt" of the Sandy Springs Group, stratigraphic nomenclature abandoned by Holm-Denoma (2006) and Tull et al. (2014) and discussed herein. In the central-southern portions of the AshlandWedowee-Emuckfaw belt in Alabama, the Emuckfaw Group can be subdivided into a structurally and/or stratigraphically lower unit (Josie Leg Formation) composed of variably garnetiferous two-mica schist and fine-grained biotite paragneiss interlayered with orthoamphibolite (Bieler and Deininger, 1987; Tull et al., 2014). In the Alabama portion of the eastern Blue Ridge, the lower contact of the Emuckfaw Group with the underlying Wedowee Group is commonly marked by gradation of highly graphitic schists of the Wedowee Group into non-graphitic or graphite-poor schists of the Josie Leg Formation over an interval 


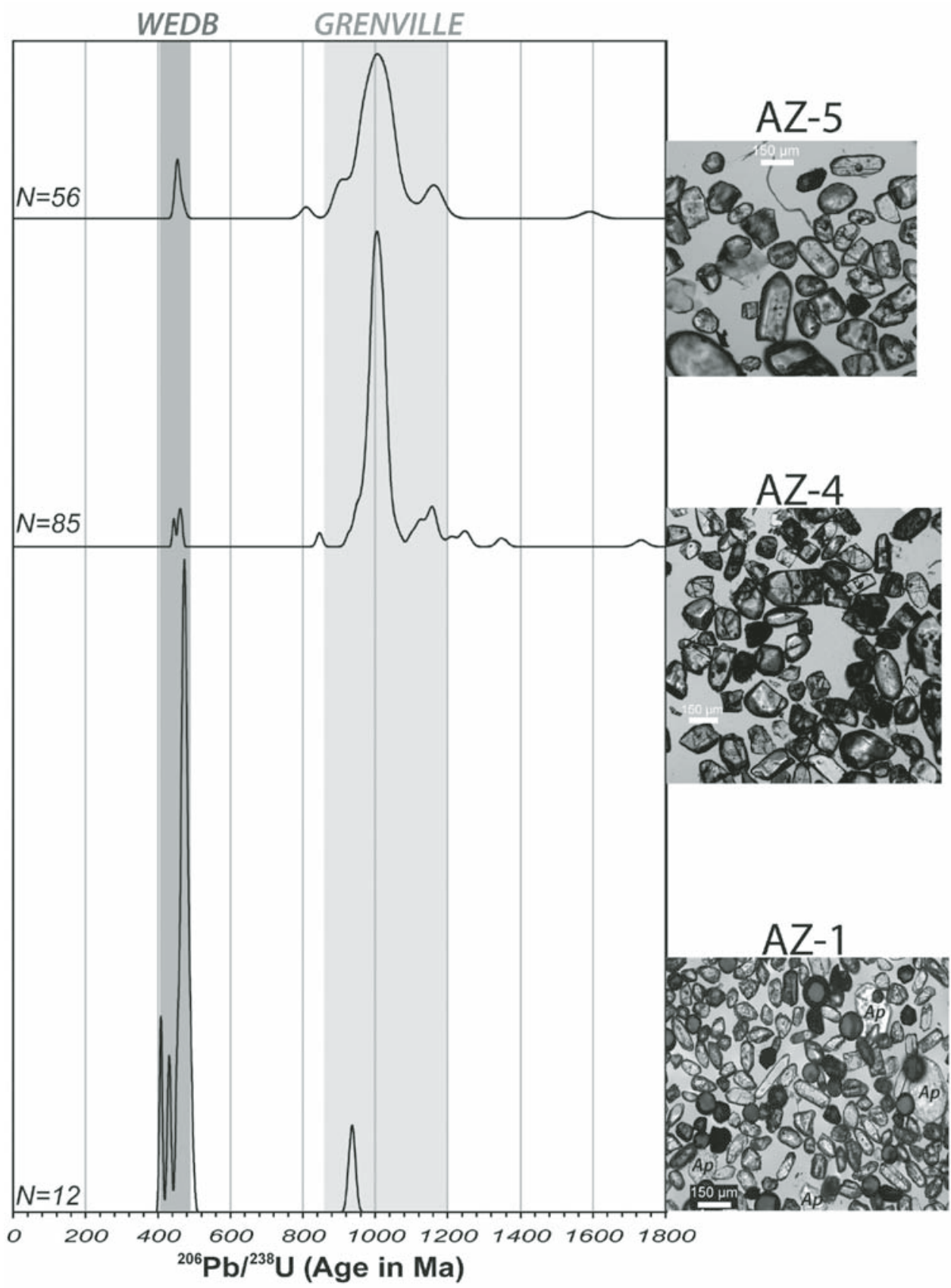

Figure 7. Relative probability plots of detrital zircon populations from the Wedowee and Emuckfaw Groups, including zircon photomicrographs.

of 5-15 m, often coinciding with the appearance of orthoamphibolite in the lower Emuckfaw Group. Structurally and stratigraphically above the Josie Leg Formation, schist-paragneiss of the Timbergut Formation is commonly more graphitic and less garnetiferous, and is interlayered with less common quartzite, metaconglomerate, metadiamictite, and rare calc-silicate rocks (Bieler and Deininger, 1987; Tull et al., 2014).

Detrital zircon from a metagraywacke in the lower Emuckfaw Group (Josie Leg Formation, AZ-1, Fig. 7, location-Fig. 2) yielded a significant population with an age peak centered at $474 \mathrm{Ma}$ (7 grains). The majority of the grains analyzed were
$>15 \%$ discordant and not included in the probability density function plot (Fig. 7). However, the majority of concordant grains are Ordovician and like the Wedowee, they confirm an Ordovician source (Tull et al., 2014). Additionally, zircon morphologies, including prismatic grains of potentially volcanic origin, limited abrasion, and the presence of detrital apatite, all suggest a proximal source for this Ordovician zircon population. Lower-Middle Ordovician detrital zircons in both the Wedowee and Emuckfaw Groups, along-strike stratigraphic correlations with LowerMiddle Ordovician metavolcanic units in Georgia, and bracketing 458-430 Ma felsic intrusions (e.g., Kowaliga and Villa Rica 
fld039-02 1st pgs page 33

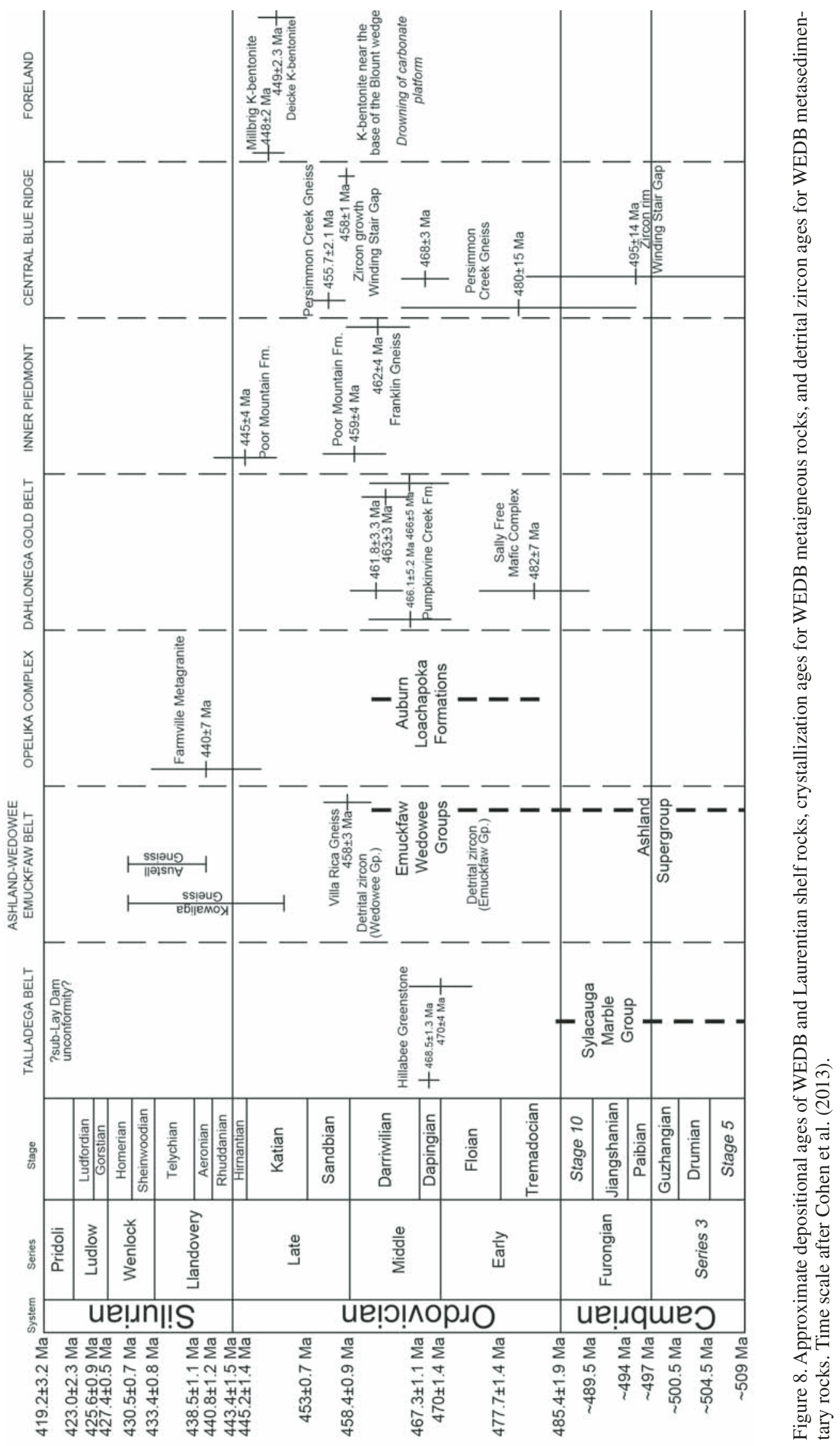


Gneisses) indicate the presence of a significant Lower-Middle Ordovician basin receiving detritus from Grenville source rocks and a proximal volcanic source. Furthermore, the conformable base of the Wedowee Group with the underlying Ashland Supergroup is interpreted as having formed on the uppermost Neoproterozoic-earliest Paleozoic Laurentian slope-rise. This relationship indicates this Lower-Middle Ordovician WEDB was built on the edge of the Laurentian margin outboard of the continental hinge zone (Tull et al., 2014).

\section{Opelika Group}

The Opelika Group of the Opelika Complex (Bentley and Neathery, 1970; Sears et al., 1981), southeast of the Dadeville Complex, includes a sequence of rocks lying between the Stonewall Line shear zone on the northwest and Towaliga fault on the southeast, and is divided into two stratigraphic packages: the structurally lower Auburn Formation and upper Loachapoka Formation (Bentley and Neathery, 1970; Sears et al., 1981). The Auburn Formation consists predominantly of variably garnetiferous biotite gneiss interlayered with kyanite-staurolite- bearing, variably garnetiferous two-mica schist and rare calc-silicate pods (Bentley and Neathery, 1970; Goldberg and Steltenpohl, 1990). These migmatitic units have been interpreted as sequences of metamorphosed graywacke and pelitic rocks (Bentley and Neathery, 1970) or as the results of metasomatism of a paragneiss during intrusion of the Farmville Metagranite (Colberg and Chalokwu, 1990). The structurally upper Loachapoka Formation consists of a $>1-\mathrm{km}$-thick package of interlayered kyanite and sillimanite, variably graphitic and garnetiferous schists, interlayered with quartzite and minor amphibolite (Bentley and Neathery, 1970; Goldberg and Steltenpohl, 1990). Sillimanitebearing, garnetiferous, micaceous, feldspathic quartzite layers as much as $80 \mathrm{~m}$ thick (Grimes et al., 1993) have been referred to as Saugahatchee quartzite or Saugahatchee quartzite member and are mapped as discontinuous bodies for $>180 \mathrm{~km}$ along strike into the central Georgia Piedmont (Bentley and Neathery, 1970; Sears et al., 1981; Goldberg and Steltenpohl, 1990). Both units have been intruded by the Farmville Metagranite (Bottle Granite of Bentley and Neathery, 1970), a garnetiferous, muscovite, biotite, feldspathic orthogneiss. The protolith is interpreted to be a peraluminous, S-type granite, which formed as a result of crustal anatexis (Goldberg and Steltenpohl, 1990). Steltenpohl et al. (2005) reported complex U-Pb systematics from SHRIMP $\mathrm{U} / \mathrm{Pb}$ zircon analyses of a sample of Farmville orthogneiss. The eight youngest grains plot along concordia, with ${ }^{206} \mathrm{~Pb} /{ }^{238} \mathrm{U}$ ages ranging from $477 \pm 20 \mathrm{Ma}$ to $425 \pm 18 \mathrm{Ma}$, but also include inherited grains with ages of $1476 \pm 34 \mathrm{Ma}\left({ }^{207} \mathrm{~Pb} /{ }^{206} \mathrm{~Pb}\right)$ and $564 \pm 24 \mathrm{Ma}\left({ }^{206} \mathrm{~Pb} /{ }^{238} \mathrm{U}\right)$. Hawkins et al. (2013) reported 36 additional zircon analyses of the Farmville orthogneiss, assigning it a crystallization age of $440 \pm 7 \mathrm{Ma}\left({ }^{206} \mathrm{~Pb} /{ }^{238} \mathrm{~Pb}\right)$. The complex age systematics along with a whole-rock $\mathrm{Nd}$ depleted-mantle model age of $1.12 \mathrm{Ga}$ suggest a source consisting partially of Grenville crustal components.

\section{Jacksons Gap Group}

Within the kinematically complex Brevard fault zone of Alabama, an $\sim 2-\mathrm{km}$-thick sequence of rocks referred to as the Jacksons Gap Group (Fig. 2) is bounded by the Abanda fault on its northwest and by the synmetamorphic Katy Creek fault to the southeast (Wielchowsky, 1983; Steltenpohl et al., 1990; Sterling, 2006). Lithologies of the Jacksons Gap Group include chlorite hornblende biotite schist, garnetiferous graphitic schist, calcareous micaceous quartzite, metaconglomerate, orthogneiss and uncommon marble and amphibolite, which formed at lower greenschist to lower amphibolite facies (Bentley and Neathery, 1970; Wielchowsky, 1983; Steltenpohl et al., 1990; Sterling, 2006). Protoliths are generally interpreted as interlayered sequences of pelite, calcareous pelite, carbonate, sandstone, chert, and volcanic rocks (Bentley and Neathery, 1970; Johnson, 1988; Steltenpohl et al., 1990; Sterling, 2006). Shear fabrics are common (phyllonites and mylonites) and stratigraphic sequences may be repeated in tectonically dismembered faults zones (e.g., Lake Martin Duplex of Sterling, 2006). Metasandstone and conglomerate units of the distinctive Devils' Backbone Quartzite (Bentley and Neathery, 1970) in the Jacksons Gap Group (Tallassee quartzite of White, 2008) have been correlated with the Saugahatchee Quartzite of the Loachapoka Formation in the Opelika Complex (Grimes et al., 1993), a correlation strengthened by interpretations of White (2008) that orthogneisses of the Farmville Metagranite intruded rocks of the Jacksons Gap Group within the hinge zone of the Tallassee synform.

\section{Dahlonega Gold Belt}

Gold-bearing rocks in the Blue Ridge of northwest Georgia have been historically assigned to the Dahlonega and Carroll County gold belts. They extend for more than $300 \mathrm{~km}$ from northwest Georgia to western North Carolina, and lie structurally above the western Blue Ridge in the hanging wall of the Allatoona fault northeast of the Alabama state line (Fig. 2), a relationship that becomes less clear in northern Georgia and North Carolina. West of Dahlonega, Georgia, rocks of the central Blue Ridge - framed by the Hayesville and Soque River faults-separate the western Blue Ridge and Dahlonega gold belts (Fig. 2). However, a number of researchers (e.g., Nelson and Gillon, 1985; Bream et al., 2004; Hatcher et al., 2007; Merschat et al., 2010) interpret these rocks as a klippe structurally above both the Dahlonega gold belt and western Blue Ridge, suggesting that they root southeast of the Dahlonega gold belt. In this interpretation, rocks of the Dahlonega gold belt extend beneath the central Blue Ridge and reemerge to the northeast in the Great Balsam Mountains window west of Asheville, North Carolina. Beneath the central Blue Ridge thrust sheet (Cowrock and Cartoogechaye terranes), rocks of the Dahlonega gold belt are either in stratigraphic or faulted contact with rocks of the western Blue Ridge (Hatcher et al., 2007). Like rocks of the Ashland-Wedowee-Emuckfaw belt, which lie structurally above 
rocks of the western Blue Ridge-equivalent Talladega belt in Alabama, we assign rocks of the Dahlonega gold belt to the eastern Blue Ridge because of their structural position above rocks of the western Blue Ridge in Georgia and North Carolina. Other workers (e.g., Merschat et al., 2010), however, have considered rocks of the Dahlonega gold belt to be part of the central Blue Ridge terranes in north Georgia due to the belt's intermediate position between thrust sheets mapped as western and eastern (western Tugaloo terrane of Hatcher et al., 2007) Blue Ridge in north Georgia and North Carolina. The structural (stratigraphic?) base of the Dahlonega gold belt beneath the central Blue Ridge is not exposed, but the southeastern and structural top of the belt in Georgia and North Carolina is the Chattahoochee and Holland Mountain faults, which separate it from the western Tugaloo terrane to the southeast (Hatcher et al., 2007; Merschat et al., 2010).

Rocks of the Dahlonega gold belt have been assigned to a variety of stratigraphic units due to structural separation of the belt beneath the central Blue Ridge klippe and along-strike variation in volcanic versus sedimentary components. From northeast to southwest, these units include the Otto Formation in the Great Balsam Mountains window and immediately southeast of the central Blue Ridge klippe, the Helen Group and correlative Pumpkinvine Creek and Canton Formations in North Carolina and north-northwestern Georgia, respectively, and the Sally Free mafic complex west of Dahlonega, Georgia (Gillon, 1982; Nelson and Gillon, 1985; Hatcher, 1988; German, 1989; Settles, 2002). Rocks in the southwesternmost Georgia eastern Blue Ridge, immediately east of the Alabama state line have been assigned to a third unit, the "western belt of the Sandy Springs Group" by a number of workers (e.g., McConnell and Abrams, 1984; German, 1989). We follow the example of Holm-Denoma (2006) and Tull et al. $(2012,2014)$ and assign these rocks to the Wedowee and Emuckfaw Groups, formally abandoning the term "western Sandy Springs Group" for rocks between the Allatoona fault and Brevard fault zone in western central Georgia.

\section{Otto Formation}

In the Great Balsam Mountains window and immediately southeast of the central Blue Ridge, between the Shope River fault and Chattahoochee-Holland Mountain faults, the Otto Formation is commonly divided into two units: one dominated by metasandstone and one consisting of interlayered schistmetasandstone (Lamb, 2001; Merschat, 2009). Both metasandstones and schists are locally sillimanite-bearing, sulfidic, and migmatitic. Metasandstones are commonly micaceous, garnetiferous, and feldspathic, while biotite-muscovite schists are commonly garnetiferous and quartzose. Schist-metasandstone sequences also contain subordinate micaceous, garnetiferous, feldspathic quartzose gneiss, and calc-silicate bodies, in addition to isolated lenses of amphibolite and altered ultramafic bodies (Merschat, 2009). Detrital zircons from the Otto Formation yield abundant Mesoproterozoic (1.3-1.0 Ga) and Neoproterozoic (900-700 Ma) ages (Bream et al., 2004; Merschat et al., 2010), but also a small population of Archean-Paleoproterozoic grains
(2.7-1.6 Ga, Bream et al., 2004). Rocks of the Otto Formation in the northeasternmost segment of the Dahlonega gold belt have been correlated with those of the Helen Group farther to the southwest (Hatcher, 1988).

\section{Helen Group}

Nelson and Gillon (1985) divided the Helen Group in North Carolina and northern Georgia into three subunits, from northwest to southeast: the Robertstown, Horton, and Nacoochee Formations. The southeastern and structurally lowest Nacoochee Formation consists of thick amphibolites interlayered with variably graphitic mica schist, micaceous quartzites, and biotite feldspathic paragneiss. The contact with the structurally overlying Horton Formation is gradational, with graphitic schists and amphibolites of the Nacoochee Formation transitioning into micaceous, feldspathic quartzites, and locally sulfidic metasiltstones, interlayered with subordinate amphibolite and aluminous mica schist of the Horton Formation. The boundary between the structurally uppermost Robertstown Formation and underlying Horton Formation is conformable. The Robertstown is composed predominantly of muscovite-biotite feldspathic quartzites interlayered with micaceous schist, micaceous feldspathic paragneiss (metagraywacke?), and minor metaconglomerate and amphibolite (Gillon, 1982; Nelson and Gillon, 1985; German, 1985).

\section{Sally Free Mafic Complex}

West-northwest of Dahlonega, Georgia, structurally below rocks mapped as the Helen Group (Nelson and Gillon, 1985) and New Georgia Group (German, 1985), rocks of the Sally Free mafic complex have been interpreted as either lying in a separate thrust sheet (German, 1985) or as forming the structurally lowest stratigraphy of the Dahlonega gold belt (Settles, 2002). German (1985) mapped the Allatoona fault at the tectonic base of the Dahlonega gold belt along a generally northeast trace into northeast Lumpkin County (plate 1 in German, 1985), northeast of the city of Dahlonega, where he interprets it as being truncated along the Shope Fork fault. Settles (2002) mapped a large $\left(>34 \mathrm{~km}^{2}\right)$ bimodal metaigneous complex, including orthoamphibolites, metagabbros, and felsic-intermediate orthogneiss, in the region between German's (1985) Allatoona and Shope Fork faults, naming it the Sally Free mafic complex. Based on a comparison of lithology, geochemistry, and metamorphic grade between rocks of the western Blue Ridge, central Blue Ridge, and Dahlonega gold belt, Settles (2002) interpreted rocks of the Sally Free mafic complex to lie, at least over part of its boundary, in stratigraphic contact with rocks of the Otto Formation (Helen Group of Nelson and Gillon, 1985; New Georgia Group of German, 1985). In this interpretation, the trace of the Allatoona fault turns abruptly north and northwest in the vicinity of Dahlonega, Georgia, where it is truncated by the Hayesville-Soque River fault at the base of the central Blue Ridge. Significantly, a felsic gneiss (Cane Creek felsic gneiss) interpreted as a metamorphosed shallow intrusive or volcanic sequence within the Sally Free mafic complex yielded a U-Pb age of $482 \pm 7$ Ma (Settles, 2002; Bream, 2003), suggesting 
an Early Ordovician age for this metaigneous complex. In the interpretation of Settles (2002), this would place the Lower Ordovician Sally Free mafic complex structurally and stratigraphically below rocks mapped as the Middle Ordovician Pumpkinvine Creek Formation (466.1 \pm 5.2 Ma and 461.8 \pm 3.3 Ma, HolmDenoma and Das, 2010; $463 \pm 3 \mathrm{Ma}$ and $466 \pm 5 \mathrm{Ma}$, Thomas, 2001), and make it the oldest known igneous sequence in the Dahlonega gold belt (Tull et al., 2014). In the alternative interpretation of German (1985), the Sally Free mafic complex would belong within the central Blue Ridge thrust sheet and would not be part of the WEDB.

\section{New Georgia Group including Pumpkinvine Creek and Canton Formations}

McConnell and Abrams (1984) described rocks of the New Georgia Group as a sequence of predominantly bimodal metavolcanic rocks interlayered with minor metapelites. The principal gold-bearing unit in the Georgia eastern Blue Ridge, the New Georgia Group stretches from Carroll County, east of the Alabama state line, northeast to Cobb and Paulding Counties, Georgia. German (1985, 1988, 1989), however, used the term to include units stretching from Carroll County to Helen, Georgia, in the Dahlonega gold belt, correlating it with rocks of the Pumpkinvine Creek and Canton Formations and Helen Group and establishing a number of subunits. Subsequent work on the New Georgia Group revised the nomenclature associated with the Pumpkinvine Creek Formation (Holm-Denoma, 2006; HolmDenoma and Das, 2010). Although German (1985, 1988, 1989) and McConnell and Abrams (1984) proposed a stratigraphic sequence for rocks of the New Georgia Group and surrounding units at the southwestern end of the Dahlonega gold belt, east of the Alabama state line, we propose that much of these sequences be subsumed into previously established, equivalent stratigraphic units in Alabama due to reinterpretation of regional structural relationships, presented herein (Tull et al., 2012, 2014).

At the structural base of the Dahlonega gold belt, immediately southeast of the Allatoona fault, the Pumpkinvine Creek Formation is a bimodal metavolcanic unit consisting predominantly of orthoamphibolite interlayered with subordinate felsic gneiss (Galts Ferry gneiss member of McConnell, 1980, and Barlow gneiss of German, 1985) in addition to minor ferruginous quartzite and garnetiferous quartzose two-mica schist (Holm-Denoma, 2006; Holm-Denoma and Das, 2010). The informally designated Galts Ferry and correlative Barlow gneiss (German, 1985, 1989) of the Pumpkinvine Creek Formation yield consistent Middle Ordovician zircon ages (Thomas, 2001; Holm-Denoma and Das, 2010), whereas trace element and isotopic geochemistry from intercalated orthoamphibolites suggest development in a suprasubduction setting — specifically a backarc (Holm-Denoma and Das, 2010). In stratigraphic contact with the Pumpkinvine Creek Formation, rocks of the Canton Formation are dominated by variably graphitic, garnetiferous two-mica schist (metapelite), but also include subordinate biotite plagioclase quartz gneiss (metagraywacke?) and amphibolite (McCo- nnell and Abrams, 1984; German, 1985; Holm-Denoma, 2006; Holm-Denoma and Das, 2010). In the northeastern Dahlonega gold belt, German (1985) further subdivided the Canton Formation into four subunits, the Proctor Creek member, Palmer Creek member, Chestatee member, and Helen member. HolmDenoma (2006) subdivided the Canton Formation near Canton, Georgia, into three subunits, the Bells Ferry, Blanket Creek, and Little River members. Structurally above the Canton Formation, a sequence of amphibolite gneiss, garnet two-mica schist, banded iron formation, and chlorite schist has been called the Univeter Formation (Little River member of Holm-Denoma, 2006), which McConnell and Abrams (1984) subdivide into the Lost Mountain Amphibolite and Rose Creek Schist members. The Mud Creek Formation is exposed near Villa Rica, Georgia, at the structural top of the New Georgia Group and consists of magnetite-bearing quartzite (Cedar Lake quartzite), interlayered with amphibolite and garnetiferous feldspathic biotite gneiss (McConnell and Abrams, 1984; German, 1985, 1988, 1989). A biotite quartzose feldspathic orthogneiss (Villa Rica gneiss) intruding rocks of the Mud Creek Formation (U-Pb age of $458 \pm 3 \mathrm{Ma}$ ) provides an upper age constraint for deposition of the New Georgia Group (Thomas, 2001).

McConnell and Abrams (1984) and German (1989) interpret the overall structure of the Dahlonega gold belt and New Georgia Group, at least in the southwestern end of the belt, as a mapscale antiformal nappe (half-wavelength $>35 \mathrm{~km}$ ) overturned to the northwest, with rocks of the New Georgia Group defining the core of the structure. In central Carroll County, immediately east of the Alabama state line, Abrams and McConnell (1984) and German (1989) map a series of rocks on either side of this proposed antiformal nappe as "western Sandy Springs Group," which defines the northwestern and southeastern "limbs" of their structure. German (1989) traces stratigraphy of the "western Sandy Springs Group" to the state line, inferring that these units can be traced into the Ashland-Wedowee-Emuckfaw belt of Alabama. Rocks of the "western Sandy Springs Group" were initially proposed by McConnell and Abrams (1984) to be stratigraphic equivalents of rocks of the Sandy Springs Group (Higgins and McConnell, 1978) that occur immediately east of the Chattahoochee fault in the Chattahoochee thrust sheet (western Tugaloo terrane of Hatcher et al., 2007). Following the example of Holm-Denoma (2006) and Tull et al. (2012, 2014), we suggest that the term "western Sandy Springs Group" should be abandoned due to the difficulty of correlating non-unique stratigraphy across a major tectonic boundary (Chattahoochee fault), where units on either side have experienced different degrees of deformation and metamorphism. Thus, rocks of the "western Sandy Springs Group" have been reassigned to units of the New Georgia Group (Holm-Denoma, 2006) or to Wedowee and Emuckfaw stratigraphy established in the Ashland-Wedowee-Emuckfaw belt of Alabama (Tull et al., 2014).

In contrast to German's (1989) structural interpretation, a number of authors (e.g., Hatcher et al., 2007; Merschat et al., 2010) have suggested that rocks of the New Georgia Group lie in 
a separate thrust sheet than those of the Emuckfaw and Wedowee (or German's "western Sandy Springs sequence"), interpreting the Ashland-Wedowee-Emuckfaw belt as a structurally higher thrust sheet than the one containing the New Georgia Group. However, our detailed mapping of the Emuckfaw-Wedowee contact from eastern Alabama to northwestern Georgia (Fig. 2) indicates that stratigraphic sequences from the Ashland-Wedowee-Emuckfaw belt can be mapped across these proposed faults and are correlative with units within the New Georgia Group (Holm-Denoma, 2006; Gilmer and Barineau, 2012; Tull et al., 2012, 2014), although rocks of the Wedowee, New Georgia, and Emuckfaw Groups may lie in a separate thrust sheet than those of the structurally lower Pumpkinvine Creek and Canton Formations.

\section{CORRELATION OF WEDOWEE-EMUCKFAW- DAHLONEGA BASIN ROCKS}

Although rocks in each of the regions discussed above have been mapped as distinct, or locally related, stratigraphic packages, new and existing data suggest that they are spatially and temporally related (Tull et al., 2014). This evidence includes (1) field relations and correlation of units at the junction between the Ashland-Wedowee-Emuckfaw belt and southwestern extent of the Dahlonega gold belt and New Georgia Group; (2) previous correlations between the Ashland-Wedowee-Emuckfaw belt and the Opelika Complex; (3) correlation of part of the Opelika Group in the Opelika Complex with rocks of the Jacksons Gap Group in the Brevard fault zone; (4) similarities in the crystallization age of bimodal metavolcanic units from the Talladega belt and Dahlonega gold belt and the depositional age of metasedimentary units within the Ashland-Wedowee-Emuckfaw belt; (5) similarities in the geochemical character of metamorphosed mafic and pelitic-psammitic units from the New Georgia, Emuckfaw, Wedowee, and Jacksons Gap Groups; and (6) similarities in the tectonic setting for metamorphosed igneous and sedimentary units on the basis of tectonic discrimination diagrams. We explore each of these links below.

\section{Ashland-Wedowee-Emuckfaw-Dahlonega Gold Belts}

Extensive work in the Dahlonega gold belt of Georgia and North Carolina has resulted in correlation of units from the northeastern (Otto Formation and Helen Group) to southwestern (Pumpkinvine Creek Formation and New Georgia Group) end of the belt (Nelson and Gillon, 1985; Hatcher, 1988; German, 1985, 1989; Holm-Denoma, 2006). Similarly, extensive work in the Ashland-Wedowee-Emuckfaw belt of Alabama has resulted in correlation of units from the Gulf Coastal Plain in the southwest to the Georgia state line in the northeast (Neathery, 1975; Tull, 1978; Drummond, 1986; Drummond et al., 1988; Allison, 1992; Tull et al., 2014). Although some workers have proposed that the two belts lie in separate thrust sheets (e.g., Hatcher et al., 2007), others (e.g., McConnell and Abrams, 1984; German, 1989; Holm-Denoma, 2006; Tull et al., 2012, 2014) have sug- gested stratigraphic connections between rocks of the Alabama and Georgia eastern Blue Ridge. Mapping by the latter authors suggests that rocks of the Wedowee and Emuckfaw Groups can be traced from southwest of the Alabama-Georgia state line, northeast into rocks previously assigned to the New Georgia Group and "western Sandy Springs Group" (Fig. 2). No evidence for fault(s) separating these two sequences is apparent, and we consider rocks of the New Georgia Group in western Georgia to be along-strike equivalents of the Emuckfaw Group in eastern Alabama, with each underlain by rocks of the Wedowee Group. Less than $20 \%$ of the Emuckfaw section in Alabama and west Georgia consists of amphibolite (metabasalt), with most of the section being composed of metasedimentary rocks dominated by mica schist. However, northeastward in Carroll County, Georgia, the volume of metabasalt increases significantly in this section, becoming the predominant lithology. This section is also marked by an abundance of banded iron formation and metagabbro bodies (Fig. 2). This massive sequence of dominantly mafic metavolcanic rocks occupies the type area of the New Georgia Group and appears to be centered on the Mulberry Rock subregional recess, a structurally complex, late (Alleghanian) composite halfwindow formed from erosional breaching of an oblique northsouth-trending antiform. This structure (Fig. 2) is bounded by the Allatoona fault, includes rocks of the Talladega belt and the Mulberry Rock Gneiss on its interior, with rocks of the eastern Blue Ridge in the hanging wall on the eastern and western margins (Holm-Denoma, 2006). Within the interior, the Mulberry Rock Gneiss occupies a separate structural panel, being separated from rocks of both the eastern Blue Ridge and western Blue Ridge by faults (Fig. 2). Although the Silurian Mulberry Rock Gneiss (ca. 432 Ma, Holm-Denoma, 2006) cannot be definitively linked with the eastern Blue Ridge, it is similar in age and geochemical character to the ca. 440-430 Ma Austell Gneiss (Higgins et al., 1997; Tull et al., 2012) in the footwall of the Chattahoochee fault, suggesting it may share a genetic origin. If the Mulberry Rock Gneiss originated in the eastern Blue Ridge, then the structural panel in which it is located may represent part of a hanging-wall duplex along the Allatoona fault.

Because of shear fabrics, significant differences in lithologic character, and truncation of units along the southeastern flank of the Pumpkinvine Creek and Canton Formations, a number of workers have interpreted this sequence of rocks as lying within a discrete structural panel between rocks of the western Blue Ridge and/or Talladega belt on its northwest and the New Georgia Group on its southeast (McConnell, 1980; McConnell and Abrams, 1984; German, 1988; Vincent et al., 1990; Holm Denoma, 2006). In this interpretation, the base of the Pumpkinvine Creek and Canton Formations lies in the hanging wall of the Allatoona fault and in the footwall of what we refer to here as the Burnt Hickory Ridge fault (Fig. 2), which separates it from units of the New Georgia Group. It is this thrust panel containing the Pumpkinvine Creek and Canton Formations that extends northeastward from the internal rim of the Mulberry Rock recess into the Dahlonega gold belt to the northeast for $>120 \mathrm{~km}$ to 
Dahlonega, or more than twice that far if it is correlative with the Otto Formation. Although rocks of the Pumpkinvine Creek Formation are not found southwest of the recess, a thin slice of the Canton Formation flanks both sides of the recess. West and southwest of the recess, the Allatoona fault cuts upward through rocks of the Canton Formation and the Burnt Hickory Ridge fault into the overlying Wedowee Group. Along the west flank of the recess, both the upper Wedowee and lower Emuckfaw/New Georgia Group sequences truncate against the Burnt Hickory Ridge fault (Fig. 2).

The Pumpkinvine Creek Formation and associated units (Canton Formation, Helen Group) of the Dahlonega gold belt form a fault-bounded sequence 3-6 km wide, with a structural thickness of $\sim 4 \mathrm{~km}$ along the northwest flank of the eastern Blue Ridge northeast of the Mulberry Rock recess. From Dahlonega southwestward to the Mulberry Rock recess, the northwest boundary of this sequence is the Allatoona fault. The southeastbounding fault against rocks of the New Georgia Group is the Burnt Hickory Ridge fault, but northeast of Canton this boundary is marked by the overlying Chattahoochee fault, locally referred to as the Dahlonega fault (Nelson and Gillon, 1985), which eliminates most or all of the main body of New Georgia Group rocks northeast of Canton, Georgia. Although the southeast boundary of the Pumpkinvine Creek and Canton Formations is a fault, traditionally this sequence has been incorporated as a stratigraphic component within the New Georgia Group (McConnell and Abrams, 1984; German, 1985; Gillon, 1989), an interpretation that we support. However, it is clear that the exact correlation and stratigraphic position of the Pumpkinvine Creek and Canton Formations relative to the New Georgia Group is somewhat equivocal, because of the presence of bounding thrust faults on both structurally lower and upper margins.

Assuming northwest-directed thrust displacement on the Allatoona fault, and based upon the position of innermost exposures of the Mulberry Rock Gneiss within the composite halfwindow at its southern tip, a minimal horizontal component of net slip on this fault (Allatoona) at the base of the Pumpkinvine Creek and Canton Formations relative to the Talladega belt footwall is $14 \mathrm{~km}$. Likewise, the minimal horizontal component of net slip is also $14 \mathrm{~km}$ on the Burnt Hickory Ridge fault between the Pumpkinvine Creek and Canton Formations and overlying rocks of the Emuckfaw/New Georgia Groups. This implies that the depositional site of the Pumpkinvine Creek and Canton Formations relative to the overlying rocks of the Emuckfaw/New Georgia Group was a minimum of at least several 10s of kilometers to the northwest. Significant map-scale discordance of units in both the hanging and footwalls of the Allatoona fault can be demonstrated along much of its trace southwest of the Mulberry Rock recess. In contrast, northeast of the Mulberry Rock recess, stratigraphy of the Pumpkinvine Creek and Canton Formations closely parallels the trace of the Allatoona fault for at least $120 \mathrm{~km}$, as far northeast as Dahlonega, Georgia.

It is tempting to correlate the Pumpkinvine Creek Formation with the Hillabee Greenstone (Talladega belt) as was suggested initially by McConnell (1980). We interpret both bimodal volcanic sequences to have formed along the northwest flank of the WEDB during the same time span (ca. 470$462 \mathrm{Ma}$, Fig. 8). The geochemistry of the metabasalts in both sequences is very similar (McConnell, 1980; Holm-Denoma and Das, 2010; Tull et al., 2014), and both contain similar subordinate felsic units intimately associated with the metabasalts, although there are differences in phenocryst composition in the respective felsic units. The exposed thicknesses $(2.5-4 \mathrm{~km})$ of the two units are also similar. In Georgia, both occur directly along structural strike with one another, separated by a distance of only $30 \mathrm{~km}$ (Fig. 2). However, the Pumpkinvine Creek Formation lies within the hanging wall of the Allatoona fault, whereas the Hillabee Greenstone is in the footwall. Additionally, the Pumpkinvine Creek Formation is intimately associated with metasedimentary rocks of the Canton Formation, including graphitic aluminous schist and minor metasandstone, whereas metasedimentary rocks are very rare in the Hillabee Greenstone. Approximately $80 \%$ of the spot analyses of detrital zircons from a Canton Formation metasandstone sample yield ages between 1190 and $1017 \mathrm{Ma}$, typical of Laurentian crustal materials formed during the Grenville orogeny, and likely represent sediment derived from the Laurentian continental margin (Holm-Denoma and Das, 2010). There are also important differences in structural setting between the two sequences. The Hillabee has classically been interpreted as a structural component of the Talladega belt (western Blue Ridge), whereas the Pumpkinvine Creek has classically been interpreted as part of the eastern Blue Ridge. The Hillabee is at lower greenschist facies, the same grade as its footwall but much lower grade than its hanging-wall rocks, whereas the Pumpkinvine Creek is at middle amphibolite facies, essentially the same grade as its hanging-wall rocks, but much higher grade than its Talladega belt footwall rocks. The Hillabee was emplaced along the pre-metamorphic Hillabee thrust concordantly above Talladega Group footwall stratigraphy during the latest DevonianMississippian, between ca. $375 \mathrm{Ma}$ (oldest possible uppermost Talladega Group depositional age) and ca. $330 \mathrm{Ma}$ (youngest metamorphic age; McClellan et al., 2007; Tull et al., 2007; Barineau, 2009; Tull and Barineau, 2012), whereas the Pumpkinvine Creek was emplaced during the latest Alleghanian along the Allatoona fault and is discordant to footwall stratigraphy. The Pumpkinvine Creek also locally structurally overlies plutonic rocks of the Mulberry Rock Gneiss, whereas there are no known plutonic rocks structurally beneath the Hillabee.

These differences in structural setting, however, do not mean that the two metavolcanic sequences are not, at least in part, correlative. Several important geometric relationships are notable at the location of the Mulberry Rock subregional recess (Fig. 2). These include (1) the two bimodal metavolcanic sequences mentioned above occur on opposite sides of the recess, with the Hillabee extending for $>180 \mathrm{~km}$ to the southwest and the Pumpkinvine extending for at least another $120 \mathrm{~km}$ to the northeast; (2) the Wedowee Group, which extends 
northeastward for $200 \mathrm{~km}$ from beneath the Gulf Coastal Plain, truncates along the west flank of the recess and does not occur to the northeast (Fig. 2); (3) at the latitude of the recess, the volume of metabasalt increases significantly within the Emuckfaw/New Georgia Group, becoming the predominant lithology within this sequence; (4) units structurally (stratigraphically?) higher than the Emuckfaw/New Georgia Group (Andy Mountain and Bill Arp Formations) appear from beneath the Brevard fault zone and reach maximum outcrop width and thickness to the south along the projected trace of the recess (Fig. 2); and (5) the Mulberry Rock Gneiss is only found within the recess (Fig. 2). A similar structure ( north-south-trending and south-plunging antiform) indents the Allatoona fault $35 \mathrm{~km}$ to the southwest of the Mulberry Rock recess, forming a second subregional recess southeast of Tallapoosa, Georgia (Fig. 2). It is within the interior of this recess in the footwall of this fault that the Hillabee Greenstone is exposed at its most northeastern point.

The Allatoona fault is among the latest structures to form in the southern Appalachian Alleghanian kinematic sequence, as it decapitates the regionally prominent Cartersville antiform along the Cartersville transverse zone near Cartersville, Georgia (Tull and Holm, 2005). This major fault is thus outof-sequence relative to thrust faults to the northwest, including the Talladega-Cartersville fault. The Cartersville antiform folds Pennsylvanian strata, indicating that the Allatoona fault is late Carboniferous or Permian in age. The two subregional recesses along the northwest flank of the eastern Blue Ridge at Tallapoosa and Mulberry Rock described above (Fig. 2) fold the Allatoona fault and thus must be younger than the Cartersville antiform. The geometric relationships described above suggest that these subregional recesses in the Allatoona fault reflect the effects of an underlying fundamental structure(s). The structures, most likely oblique fault ramps, deflected younger faults during late Alleghanian motion, leading to the complex footwall and hanging-wall geometries that we observe. However, other factors such as the differences in age (as much as perhaps 30 m.y.) of emplacement of the Hillabee and Pumpkinvine Creek onto the Talladega belt, and the massive accumulation of Ordovician metabasalts in the New Georgia Group centered on the Mulberry Rock recess, suggest that the fundamental structures reflected in the subregional recesses were also present during the Ordovician or earlier.

In support of the hypothesis correlating the Hillabee Greenstone and Pumpkinvine Creek Formation, we offer the following speculations:

1. The Hillabee Greenstone and Pumpkinvine Creek Formation were deposited essentially along strike as a continuous bimodal volcanic sequence flanking the southeast Laurentian outer margin along a depositional strike distance of $>300 \mathrm{~km}$ during early Middle Ordovician back-arc basin formation, but were separated by one or more oblique (north- or northwest-striking) fundamental transverse fault systems (transforms?) that had their origins in latest Precambrian Iapetus rifting (e.g., Thomas,
1991). On the northeast side of one of these transverse fault systems (Mulberry Rock), the volume of accumulated sediments (mainly pelite) was higher than along the southwest side.

2. During approximately the same time interval, several $10 \mathrm{~s}$ of kilometers to the south-southeast along the trace of this oblique fault system, Ordovician back-arc extension superposed on the earlier, Late Precambrian rift architecture, focused mafic magmatic activity along this rift system, producing the significant volume of metabasalts and other units of the New Georgia Group.

3. During later Paleozoic compressional events, this transverse fault system acted as an oblique ramp for thrust faults. During the Mississippian (possibly as late as ca. $330 \mathrm{Ma}$ ), a compressional event produced thrusting (Hillabee thrust) at the base of the Hillabee Greenstone. This selectively removed the northwest part of the backarc basin to the southwest of the oblique ramp (Hillabee Greenstone), and placed this body on top of the Middle Paleozoic Laurentian shelf prior to the composite sequence being metamorphosed to lower greenschist facies. If the trajectory of this thrust crossed the lateral ramp at Mulberry Rock to the northeast, it occurred above the stratigraphic level of the Pumpkinvine Creek and Canton sequence, leaving that sequence in the footwall to be subsequently buried to depths producing amphibolite facies mineral assemblages.

4. Following regional metamorphism, but before movement on the Allatoona fault, the main body of the eastern Blue Ridge (Wedowee, Emuckfaw, and New Georgia Groups) was detached along the Burnt Hickory Ridge fault and displaced over the Pumpkinvine Creek and Canton Formations from a position several 10s of kilometers to the southeast.

5. Subsequent latest Alleghanian out-of-sequence faulting along the Allatoona thrust had a trajectory that was rooted beneath the Pumpkinvine Creek and Canton Formations northeast of the older transverse fault system (Mulberry Rock recess), but climbed above those formations into the Burnt Hickory Ridge thrust sheet southwest of the recess. Northeast of the recess, this fault displaced the Pumpkinvine Creek and Canton Formations several 10s of kilometers to the northwest on top of the Talladega belt to a position along strike of its equivalent sequence (Hillabee) in the Talladega belt.

6. Along the trace of the Allatoona fault within the Mulberry Rock recess there are a number of significant $\sim$ northsouth footwall and hanging-wall cutoffs of stratigraphy and structure, suggesting an oblique fault ramp(s) in this orientation during movement on the Allatoona fault. The oblique antiform that forms the recess (Fig. 2) appears to be associated with movement of the Allatoona fault across this ramp, and was subsequently breached by erosion forming the half-window. 


\section{Ashland-Wedowee-Emuckfaw Belt and Opelika Complex}

Rocks of the Emuckfaw-Wedowee and Opelika Groups are separated across strike by the Dadeville Complex (Fig. 1), which lies on the southeast side of the Ashland-Wedowee-Emuckfaw belt across the Brevard fault zone and on the northwest side of the Opelika Complex across the Stonewall Line (Bentley and Neathery, 1970). Some workers (e.g., Bentley and Neathery, 1970; Grimes et al., 1993; Steltenpohl, 2005; White, 2008), however, have suggested that rocks of the Ashland-Wedowee-Emuckfaw belt are stratigraphic equivalents of units within the Opelika Complex and that both sequences are structurally connected beneath a synformal klippe consisting of the Dadeville Complex. In this interpretation, the two sequences are mapped around the southwestern end of the northeast-plunging Tallassee synform, with the Auburn Formation of the Opelika Complex representing a stratigraphic equivalent of the Emuckfaw Group in the Ashland-Wedowee-Emuckfaw belt. A number of characteristics support correlation of these two units, including similarities in lithology (interlayered sequence of metapelite and metagraywacke), intrusion of both units by lithologically similar pre-kinematic granitoids (ca. 440 Ma Farmville Metagranite and similarly aged Kowaliga gneiss), and continuity of stratigraphy around the southwestern end of the Tallassee synform (Bentley and Neathery, 1970; White, 2008). Interestingly, a number of workers have attempted to place the stratigraphy of the Emuckfaw and Opelika Groups into a structural window (e.g., Dog River and Opelika "windows" of Hatcher et al., 2007; Higgins et al., 2011; Steltenpohl et al., 2010, 2011), separating Emuckfaw and correlative Opelika Group stratigraphy from rocks of the Wedowee Group across a major "first-order" thrust fault. Additionally, they (Higgins et al., 2011) correlated the Emuckfaw with the Neoproterozoic Great Smoky Group and Lower Cambrian Chilhowee Group in the western Blue Ridge and foreland. We find this structural interpretation difficult to reconcile in the face of abundant evidence for a gradational contact between the Wedowee and Emuckfaw Groups, structural and metamorphic characteristics indicating a shared deformational history of the two units, and similar populations of Ordovician detrital zircons in both units that suggest a shared Ordovician depositional history.

\section{Opelika Group and Jacksons Gap Group}

In the core of the Tallassee synform (Fig. 2), Bentley and Neathery (1970) interpreted rocks of the Jacksons Gap Group to lie in stratigraphic contact with units of the Opelika Group. Subsequently, a number of workers (Keefer, 1992; Grimes et al., 1993; Steltenpohl, 2005; White, 2008) have suggested correlation of the Loachapoka Formation with the Jacksons Gap Group, based partly on similar sequences of quartzite, including the Saugahatchee quartzite in the Loachapoka Formation and the Devil's Backbone-Tallassee quartzite in the Jacksons Gap Group (Bentley and Neathery, 1970; Sears et al., 1981; White, 2008). Equivalency of these two units (Loachapoka Formation and Jacksons Gap Group) would suggest that the Emuckfaw
Group (correlative with the Auburn Formation) may have been in stratigraphic contact with the Jacksons Gap Group (correlative with the Loachapoka Formation) prior to development of the Abanda fault.

Using correlations between all three regions (Dahlonega gold belt, Ashland-Wedowee-Emuckfaw-New Georgia belt and Opelika Complex), a stratigraphic sequence for units of central parts of the WEDB consist of, from oldest to youngest, the Wedowee Group, Emuckfaw Group and correlative New Georgia Group and Auburn Formation, and Loachapoka Formation and correlative Jacksons Gap Group (Tull et al., 2014).

\section{GEOCHEMICAL TECTONIC DISCRIMINATION}

A growing data set for rocks in the southern Appalachians allows for comparison of geochemical characteristics between both metasedimentary and metaigneous rocks in the WEDB. Using new and previously published geochemical data, we are able to show that major and trace element analyses of rocks within the WEDB are consistent with our interpretation that they formed in a common tectonic setting-specifically seaward of the Laurentian continental hinge zone within an Ordovician back-arc basin above subducting Iapetus lithosphere.

\section{Metasedimentary Rocks}

Metasedimentary rocks within the WEDB are dominated by $(>80 \%)$ variably graphitic, quartzofeldspathic, micaceous schist (metapelite) interlayered with subordinate metapsammitic units commonly referred to as metagraywacke and biotite gneiss (paragneiss), but also include rare marble, calc-silicate, metadiamictite, metasandstones, and metaconglomerate. The predominance of thinly bedded metapelites, as well as evidence for rhythmic bedding and fining-upward sequences in metapsammitic units, has led many workers to interpret these sedimentary sequences as forming in a deep-water basin via deposition as distal turbidites (Muangnoicharoen, 1975; McConnell and Abrams, 1984; Bieler and Deininger, 1987; German, 1989; Tull et al., 2014). In addition, siliceous units, banded iron formation, and manganiferous-ferruginous alteration products of probable volcanogenic origin are often associated with WEDB metavolcanic sequences (McConnell and Abrams, 1984; German, 1989; HolmDenoma, 2006; Tull et al., 2014).

Although WEDB metasedimentary units have been mineralogically altered during dynamothermal metamorphism, research indicates that in subsolidus, volumetrically significant bodies of metasedimentary rock, mineralogical alteration occurs under essentially isochemical conditions (Bhatia, 1983; Bhatia and Crook, 1986; Argast and Donnelly, 1987; Creaser et al., 1997; Garofalo, 2012). With the exception of carbonate sequences, fluid flow in regional metamorphic terranes, even under upper amphibolite facies conditions, is limited to short $(<1 \mathrm{~m})$ distances (Tracy et al., 1983; Ague, 2003; Durand et al., 2009; Yardley, 2009). Except where significant veining 
and/or selvage zones strongly suggest localized migration of fluids (Ague, 2011), the geochemical characteristics of metasedimentary rocks are likely to reflect the bulk chemistry of their sedimentary protoliths. Data from $>100$ WEDB metasedimentary rock samples provide critical insights into the nature of the protoliths and potential tectonic settings for these units (Crawford and Medlin, 1974; Guthrie and Dean, 1989; Tull et al., 2014). $\mathrm{SiO}_{2}$ concentrations of these metasedimentary rocks vary significantly $(42 \%-96 \%)$ across the basin, but chemical variation diagrams indicate decreases in $\mathrm{Al}_{2} \mathrm{O}_{3}, \mathrm{TiO}_{2}$, total $\mathrm{Fe}$, $\mathrm{MnO}$, and $\mathrm{MgO}$, and increasing $\mathrm{Zr}$ with increasing $\mathrm{SiO}_{2}$, likely the result of sorting of sedimentary components and resultant chemical fractionation of associated elements (Fig. 9). Poor correlation of $\mathrm{SiO}_{2}$ with $\mathrm{Na}_{2} \mathrm{O}$ and $\mathrm{K}_{2} \mathrm{O}$ most likely reflects variance in feldspar ratios typical of immature flysch-like deposits containing lithic clasts. A number of geochemical discrimination techniques have been applied to metapelite sequences similar to those of the WEDB (e.g., Bhatia, 1983, 1985; Roser and Korsch, 1988). Sediments derived from oceanic-island arcs versus continental-island arcs versus active continental margins versus passive margins show a progressive increase in $\mathrm{K}_{2} \mathrm{O} / \mathrm{Na}_{2} \mathrm{O}$ and $\mathrm{Al}_{2} \mathrm{O}_{3} /\left(\mathrm{CaO}+\mathrm{Na}_{2} \mathrm{O}\right)$ and a decrease in $\mathrm{Fe}_{2} \mathrm{O}_{3}+$ $\mathrm{MgO}, \mathrm{TiO}_{2}$, and $\mathrm{Al}_{2} \mathrm{O}_{3} / \mathrm{SiO}_{2}$. On the $\mathrm{SiO}_{2}$ versus $\mathrm{K}_{2} \mathrm{O} / \mathrm{Na}_{2} \mathrm{O}$ discrimination diagram (Fig. 9A) of Roser and Korsch (1988), WEDB metapsammopelites and metapsammites plot predominantly within the passive margin and active continental margin fields, which also include back-arc basins, but overlap the volcanic arc field. This mixed provenance suggests the WEDB may have been influenced by source rocks from both a suprasubduction and passive-margin environment. This geochemical signature is consistent with our interpretations of the WEDB forming in a back-arc basin proximal to the early Paleozoic Laurentian margin. Metasedimentary sequences have high $\mathrm{TiO}_{2}$ contents $(>0.7 \%)$ and plot mostly within and above the continental margin arc and island arc fields (Fig. 9B), separate from the passive-margin field on the $\mathrm{TiO}_{2}$ versus $\mathrm{Fe}_{2} \mathrm{O}_{3}+$ $\mathrm{MgO}$ discrimination diagram (Roser and Korsch, 1986). On the $\mathrm{Al}_{2} \mathrm{O}_{3} / \mathrm{SiO}_{2}$ versus $\mathrm{Fe}_{2} \mathrm{O}_{3}+\mathrm{MgO}$ discrimination diagram (Bhatia, 1983), WEDB metasedimentary rocks have relatively high $\mathrm{Al}_{2} \mathrm{O}_{3} / \mathrm{SiO}_{2}$ and $\mathrm{Fe}_{2} \mathrm{O}_{3}+\mathrm{MgO}$ values and plot mostly within the active continental margin (back-arc), continental margin arc, and island arc fields, and away from the passive-margin field, which generally has low $\mathrm{Fe}_{2} \mathrm{O}_{3}+\mathrm{MgO}$ values due to the effects of passive-margin sediment recycling (Fig. 9C). Bhatia and Crook (1986) have shown that ocean island arc-derived sediments are characterized by $\mathrm{Ti} / \mathrm{Zr}$ ratios generally $>40$, those derived from continental-island arcs have $\mathrm{Ti} / \mathrm{Zr}$ ratios between 10 and 35, while those derived from passive margins generally have $\mathrm{Ti} / \mathrm{Zr}$ ratios $<10$. WEDB metasedimentary rocks have $\mathrm{Ti} / \mathrm{Zr}$ ratios evenly distributed across the range of oceanic and continental arcs (Fig. 9D), although high $\mathrm{TiO}_{2}$ values could reflect derivation from a proximal felsic volcanic or plutonic source. These chemical discrimination techniques support our interpretation that WEDB metapelitic-psammitic rocks received sediment from sources that included, at least in part, a suprasubduction system built on continental crust (Tull et al., 2014).

In addition to tectonic discrimination using major and trace elements, neodymium $(\mathrm{Nd})$ model ages for sedimentary units are also useful in provenance studies. Samarium and neodymium undergo fractionation when crustal material is extracted from the mantle, but such fractionation does not occur during erosion and/ or metamorphism. Therefore, $\mathrm{Sm}-\mathrm{Nd}$ isotopic data can be used to calculate model ages that represent a crustal or mantle extraction age (chondritic uniform reservoir age $\left[\mathrm{T}_{\mathrm{CHUR}}\right]$ or depleted mantle age $\left[\mathrm{T}_{\mathrm{DM}}\right]$ ) or the average crustal residence age, and thus can be used to distinguish between crustal provinces and terranes within an orogen (e.g., Patchett and Ruiz, 1989; Bennett and DePaolo, 1987). $T_{\text {CHUR }}$ ages representing time of melt extraction for igneous detrital components for rocks from the Emuckfaw and New Georgia Groups range from 0.943 to $1.119 \mathrm{Ga}$, indicative of a source dominated by Grenville terranes. One Emuckfaw sample at $1.439 \mathrm{Ga}$ (Das, 2006) is most likely representative of the eastern Granite Rhyolite Province (Becker at al., 2005). Importantly, metasedimentary rocks of the pre-WEDB Ashland Supergroup, which is stratigraphically beneath the Wedowee Group and interpreted as part of the pre-WEDB Laurentian slope and rise sequence, also yield $\mathrm{T}_{\mathrm{CHUR}}$ ages indicative of a Grenville source (1055-964 Ma; Das, 2006).

\section{Metaigneous Rocks}

WEDB metaigneous rocks include tholeiitic orthoamphibolites and interstratified metamorphosed calc-alkaline intermediate-felsic metavolcanic units generally interpreted as metamorphosed bimodal volcanic suites, although metagabbroic and ultramafic rocks are also recognized (e.g., German, 1989; Spell and Norrell, 1990; Settles, 2002; Holm-Denoma, 2006). Metavolcanic sequences are typically interpreted as submarine in origin due to the presence of intercalated deep-water sedimentary rocks (metapelites) and rare pillow structures in metabasalts (Hurst and Jones, 1973; McConnell and Abrams, 1984; Spell and Norrell, 1990; Holm-Denoma, 2006).

Geochemical data support the interpretation of an orogenic setting for the 470-468 Ma bimodal Hillabee Greenstone (Tull and Stow, 1980). Abundances of alkali and alkaline earth metals strongly suggest formation within the extensional back-arc portion of an accretionary orogenic setting in a continental margin-type arc setting (Tull et al., 2007; Tull and Barineau, 2012). Evidence for involvement of older crust in the generation of Hillabee Greenstone metadacites is evident in the $\mathrm{Hf}$ isotopic compositions of zircons. Using measured Lu/Hf isotopic ratios and the depleted mantle parameters of Nowell et al. (1998), initial Hf isotopic compositions for five grains based on an age of $468 \mathrm{Ma}$ and the $\mathrm{Hf}$ parameters of Patchett et al. (2004) ranged from -4 to -8 epsilon units and yielded depleted mantle model ages of 1.0-1.1 Ga, suggesting that older lithosphere (probably Mesoproterozoic) was involved in the generation of the felsic Hillabee magmas (Tull et al., 2007). Tectonic discrimination via trace element analysis of 

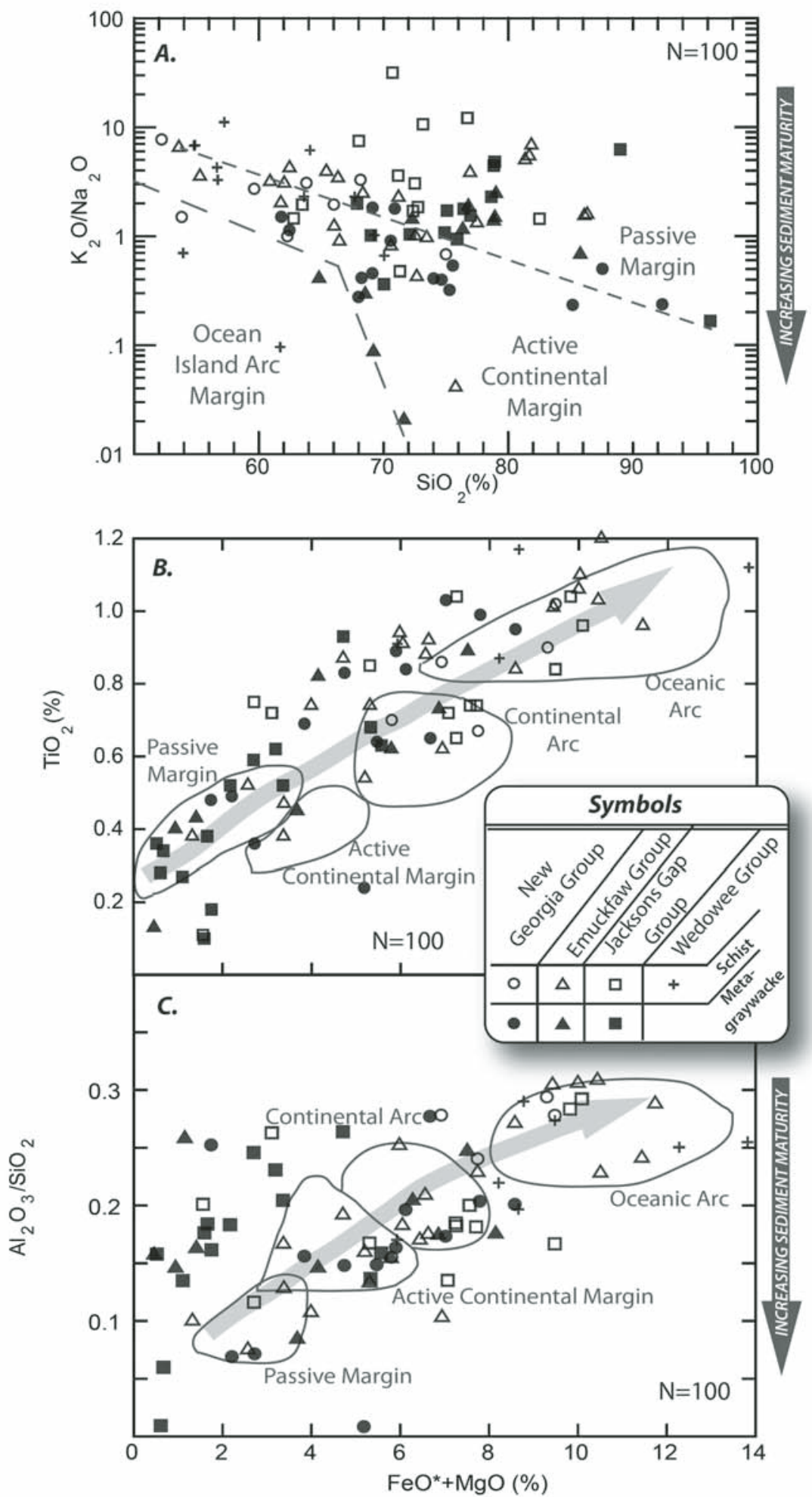

Figure 9. Tectonic discrimination diagrams of metasedimentary rocks of the WEDB. All oxides are recalculated on a volatile-free basis. Data compiled from Crawford and Medlin (1974) and Guthrie and Dean (1989) are available in DR1 from GSA Data Repository item 2014137 (available at http:// www.geosociety.org/pubs/ft2014.htm) in Tull et al. (2014). (A) After Roser and Korsch (1988). (B-C) After Bhatia (1983). Light-gray arrows show chemical variation trends, which suggest mixing between two sources (passive margin and arclike). (D) $\mathrm{Ti} / \mathrm{Zr}$ ratio discrimination plot (after Bhatia and Crook, 1986) of selected schists of the Wedowee and Emuckfaw Groups.

D.

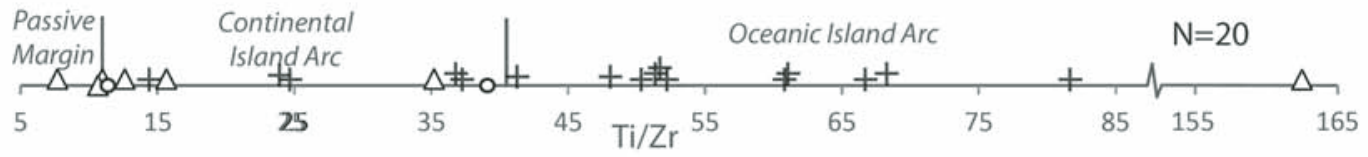


Hillabee mafic and felsic lithologies consistently suggests formation within a suprasubduction environment (Tull et al., 1998, 2007, 2014; Holm-Denoma and Das, 2010).

Metabasalt geochemistry from the Pumpkinvine Creek Formation also suggests derivation from a suprasubduction zone, more specifically a back-arc. eNd (460 Ma) values range from +3.3 to +7.7 and initial ${ }^{87} \mathrm{Sr} /{ }^{86} \mathrm{Sr}$ ratios range from 0.7044 to 0.7069 , indicating a juvenile source for the metabasalts (Holm-Denoma and Das, 2010). eNd (460 Ma) values for felsic units of the Pumpkinvine Creek Formation (e.g., Galts Ferry gneiss) range from -3.2 to +4.65 , with initial ${ }^{87} \mathrm{Sr} /{ }^{86} \mathrm{Sr}$ ratios ranging from 0.709 to 0.722 , and indicate involvement of preexisting crust in the generation of the Pumpkinvine felsic units, with incorporation of an evolved crustal component interpreted as Laurentian continental lithosphere (Holm-Denoma and Das, 2010). A similar interpretation for rocks of the Sally Free mafic complex is supported by depleted mantle $\mathrm{Nd}$ model ages of 1.2-2.0 Ga for the Cane Creek Gneiss (Bream, 2003). Other predominantly metavolcanic sequences are found in the Mud Creek Formation of the New Georgia Group in the Villa Rica area and include small ultramafic bodies with apparent maficultramafic cumulate protoliths (Spell and Norrell, 1990). Near Clayton, Georgia, the 468 Ma Lake Burton complex is composed of metabasaltic rocks with interlayered felsic extrusives and metasedimentary units (Thomas, 2001), and has been correlated with similar lithologies in the Otto Formation to the northeast (Hatcher, 1989) and the Canton and Univeter Formations to the southwest (German, 1985; Gillon, 1989). Rocks of the Lake Burton complex have geochemical similarities to both the Hillabee Greenstone and Pumpkinvine Creek Formation metavolcanic rocks and are collectively suggested to have formed in a back-arc setting (McConnell, 1980; McConnell and Abrams, 1984; Gillon, 1989; German, 1989; Hopson, 1989; Spell and Norrell, 1990; Thomas, 2001; Settles, 2002; Bream; 2003; Holm-Denoma, 2006; Holm-Denoma and Das, 2010; Tull et al., 2014).

A data set of more than 200 WEDB samples, consisting of both new and published geochemical analyses (Tull et al., 2014), was utilized to constrain the tectonic setting of mafic rocks in the region (Figs. 10, 11, and 12). In general, these mafic metavolcanic rocks are subalkaline, tholeiitic basalt, with $95 \%$ of all samples falling between $47 \%$ and $53 \% \mathrm{wt} \% \mathrm{SiO}_{2}$ (Fig. 10C). Additionally, they are moderately enriched in large ion lithophile elements, have negative $\mathrm{Nb}$ anomalies, and flat rare earth element (REE) patterns typical of suprasubductionzone mafic rocks (Fig. 11). Various tectonic discrimination diagrams based on immobile trace elements are used to determine the tectonic setting of metabasalts. For example, because V can exist in both reduced and oxidized states, whereas Ti exists only as Ti4+, the behavior of Ti versus $\mathrm{V}$ is a useful measure of oxygen fugacity. Using the discrimination diagram of Shervais (1982), significant numbers of WEDB metabasalts fall within the overlapping back-arc basin basalt-continental flood basalt field (Fig. 12A). Tectonic discrimination techniques using immobile trace elements such as $\mathrm{La}, \mathrm{Y}$, and $\mathrm{Nb}$ can also differentiate among volcanic arc, oceanic, and continental basalts. WEDB metabasalts generally plot as intermediate to volcanic arc and oceanic basalts on the discriminant diagram of Cabanis and Lecolle (1989), suggestive of continental back-arc tholeiites (Fig. 12B). In general, the collective data set of WEDB metabasalts has geochemical characteristics of both MORB (mid-ocean-ridge basalt) and island-arc tholeiite, typical of back-arc basin basalts (Taylor and Karner, 1983), and thus we interpret the majority of the metabasalts to have been erupted in a back-arc basin tectonic setting, similar to conclusions by other researchers working independently on these rocks.

A back-arc basin setting for WEDB volcanism is further strengthened by geochemical analyses of felsic rocks intercalated with mafic units. The presence and relative abundance $(15 \%-25 \%)$ of metadacites, which in part originated as pyroclastic ashflow deposits (e.g., Hillabee Greenstone), suggest an orogenic volcanic sequence (Tull and Stow, 1980), and imply volcanism over continental crust intermediate in thickness between that of an intra-oceanic island arc and that of a highly developed continental arc margin (Rogers and Ragland, 1977). The felsic metavolcanic rocks of the Hillabee Greenstone and Pumpkinvine Creek Formation are similar in composition to volcanic-arc or syncollisional granites when using $\mathrm{Nb}-\mathrm{Y}$, $\mathrm{Rb}-(\mathrm{Y}+\mathrm{Nb})$, and $\mathrm{Ta}-\mathrm{Yb}$ trace element discrimination diagrams of Pearce et al. (1984) (Tull et al., 1998; Holm-Denoma, 2006; Holm-Denoma and Das, 2010). Such an origin could imply that the felsic rocks were erupted from the volcanic arc flank proximal to the continent and emplaced as ash flows within a backarc basin that was simultaneously erupting tholeiitic basalt. Coexisting basalts and dacites in apparent bimodal suites have been reported (e.g., Wharton et al., 1995), but unlike the Hillabee and Pumpkinvine Creek, they are generally not tholeiitic and calc-alkaline, respectively. For example, bimodal suites in modern continental rifts like East Africa usually involve basaltic and felsic alkaline rocks (e.g., Davies and MacDonald, 1987), but most dacites and rhyodacites (like the Hillabee and Pumpkinvine) are calc-alkaline rocks that are associated with suprasubduction rather than intraplate rift tectonics. Using a double chondrite-normalized spidergram (normalized to chondrites and then recalculated so that all patterns have the same Yb content), Tull et al. (1998) compared trace element compositions of the Hillabee felsic rocks with dacites and rhyodacites from extensional settings, including back-arc basins from both continental and oceanic settings. The oceanic dacites and rhyodacites display approximately horizontal patterns, whereas the continental samples, particularly the Peruvian back-arc sample, have relatively steep negative slopes similar to the Hillabee felsic rock average. This comparison is consistent with Hf isotopic compositions of Hillabee metadacite zircons, which suggest that older, Mesoproterozoic(?) lithosphere was involved in the generation of the felsic Hillabee magmas, similar to whole-rock $\mathrm{Nd}$ systematics of felsic volcanic rocks from the Pumpkinvine Creek Formation. 

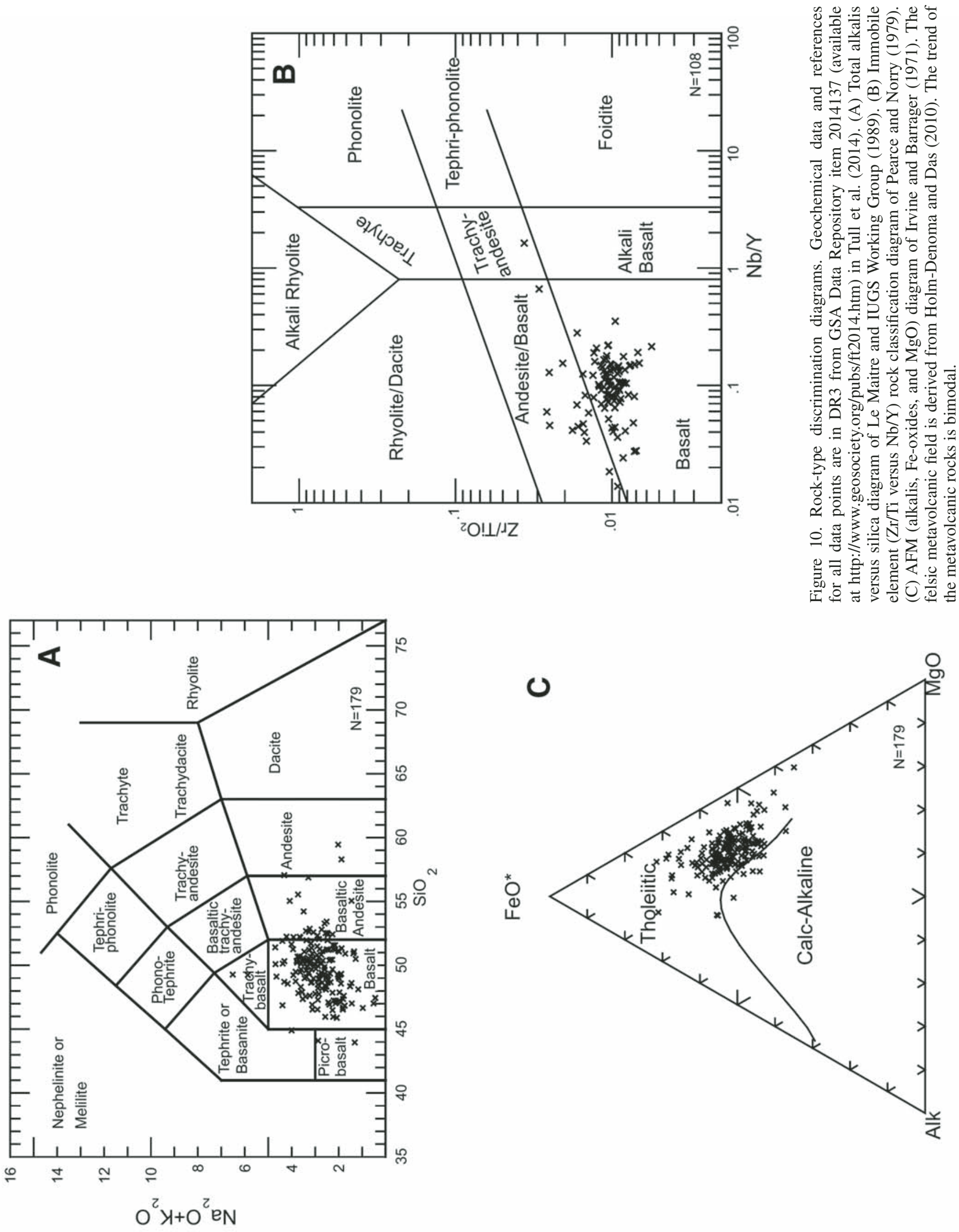


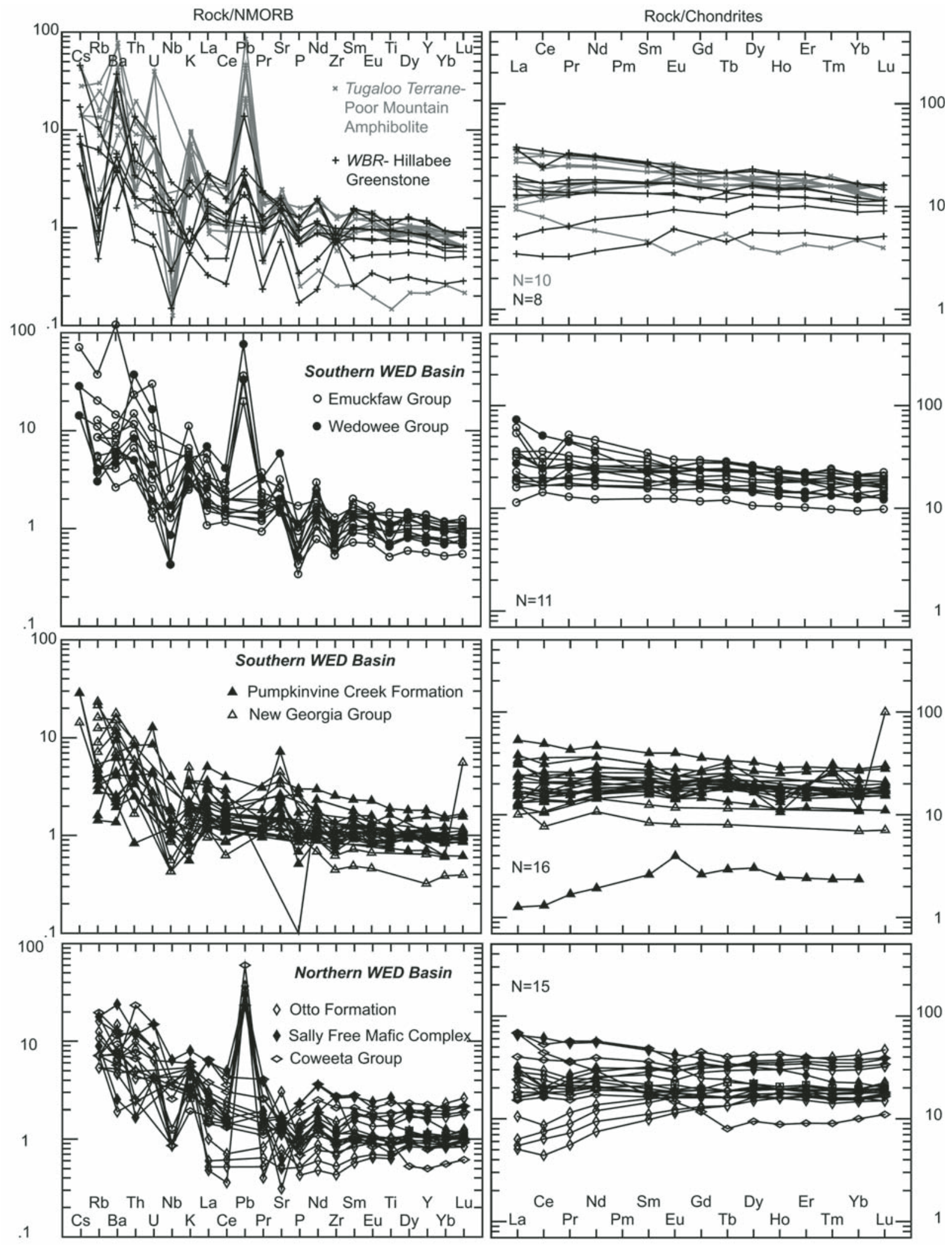

Figure 11. Normalized multi-element variation diagrams. On the left are multi-element diagrams of grouped metabasalts normalized to normal mid-ocean ridge basalt (N-MORB) values of Sun and McDonough (1989). On the right are rare earth element (REE) chondrite-normalized (Sun and McDonough, 1989) variation diagrams. Groupings were chosen based on similar geographic and tectonic settings of metabasalts for this study. WED—Wedowee-Emuckfaw-Dahlonega basin; WBR—western Blue Ridge; $\mathrm{N}$-number of metabasalts that have analyses appropriate for variation diagram study. All geochemical data are contained in DR2 from GSA Data Repository item 2014137 (available at http://www.geosociety.org/pubs/ft2014.htm) in Tull et al. (2014). 

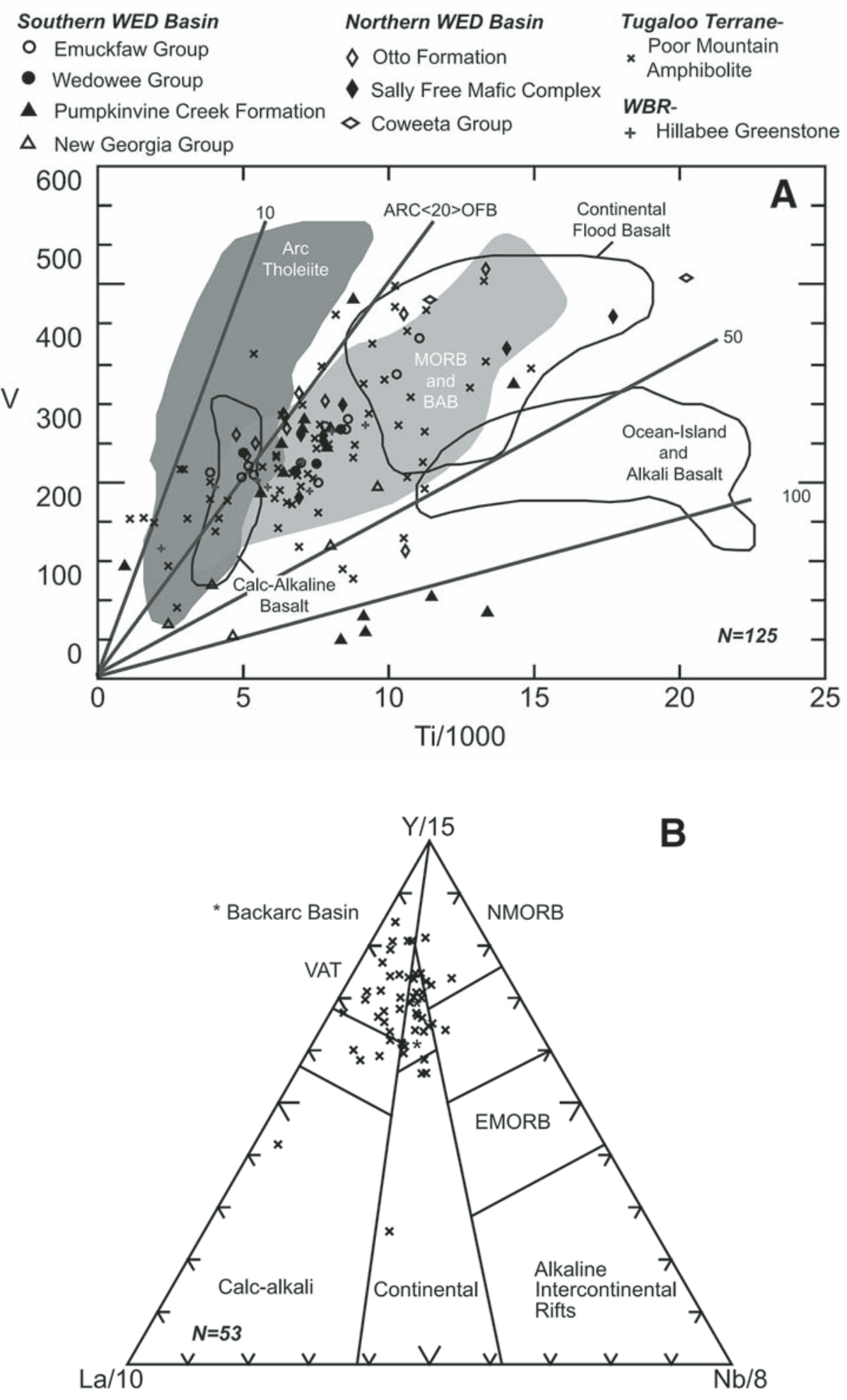

Figure 12. Tectonic discrimination diagrams for basalts. (A) Ti-V tectonic discrimination diagram of Shervais (1982). Area between $\mathrm{T} / \mathrm{V}=20$ and $\mathrm{Ti} / \mathrm{V}=50$ is mid-ocean-ridge basalt (MORB) field. (B) La-Y-Nb tectonic discrimination diagram of Cabanis and Lecolle (1989). BAB — back-arc basin basalt; EMORB - enriched MORB; N-MORBnormal MORB; OFB-ocean floor basalt; VAT_volcanic arc tholeiite; WBR-western Blue Ridge; WEDWedowee-Emuckfaw-Dahlonega basin. In B, all available data from amphibolites and greenstones in the WedoweeEmuckfaw-Dahlonega basin are shown as X's for ease of view. 


\section{Metalliferous Deposits}

Back-arc systems are commonly used as tectonic analogues for certain types of massive sulfide deposits (Ishibashi and Urabe, 1995). Volcanogenic massive sulfide and other strata-bound metalliferous deposits are hosted by a number of WEDB units, most prominently mafic to felsic volcanic units, and associated pelitic units of the New Georgia Group and the Hillabee Greenstone, as well as the Wedowee and Jacksons Gap Groups (Stow and Tull, 1982; Tull and Stow, 1982; Neathery and Hollister, 1984; McConnell and Abrams, 1984; German, 1989). These deposits typically fall into the type 1 (bimodal-mafic) and type 3 (peliticmafic) volcanogenic massive sulfide deposit categories of Franklin et al. (2005). In the New Georgia Group, gold, sulfide, magnetite, and manganese deposits formed syngenetically within a dominantly bimodal volcanic sequence and are related spatially and genetically (McConnell and Costello, 1982; McConnell and Abrams, 1984; German, 1989). The New Georgia Group sulfide deposits are both massive and disseminated, and are generally of three types: pyrite + gold, pyrite + base metal sulfide, or barren pyrite (Abrams and McConnell, 1984). Deposition of metals was contemporaneous with deposition of host rocks, and metals were leached by convecting thermal waters into chemically precipitated exhalites (siliceous zones) or incorporated into contemporaneous tuffs, flows, and sediments (German, 1989). During subsequent metamorphism, gold was remobilized in structurally controlled ore shoots in siliceous layers, where it occurs as metamorphosed auriferous zones or gold-bearing quartz bodies ("sweat-outs"). Massive and disseminated sulfide deposits are also closely associated with the gold deposits, occurring within the same units (Abrams and McConnell, 1984).

Most of these deposits are also associated with oxide- and sulfide-facies Algoma-type banded iron formation interlayered with amphibolite and with lithologies interpreted as metamorphosed alteration zones (Abrams and McConnell, 1984). On the basis of whole rock and trace element geochemistry of mafic metavolcanic host rocks and the presence of abundant interlayered metasedimentary units, German (1989) concluded that rocks of the Dahlonega and Carroll County gold deposits formed in a back-arc basin environment. Conformable zones of strata-bound massive sulfide deposits, several meters thick and extending for tens of kilometers along strike, are localized within metavolcanic rocks near the structural base of the Hillabee Greenstone near Pyriton, Alabama, and Tallapoosa, Georgia (Stow and Tull, 1982). These sulfide deposits are interpreted as synvolcanic seafloor deposits and are similar to other volcanogenic massive sulfide deposits in extensional geodynamic regimes, including backarc basins, with respect to geometry, structural history, associated rocks, base metal abundances, and igneous character of the host rocks (Stow and Tull, 1982). They are also similar to the primitive type of exhalative, strata-bound ( $\mathrm{Zn}$-Cu-pyrite) volcanogenic deposits associated with volcanic arc settings (Hutchinson, 1980). Such deposits show poor metal zoning, lack of wall-rock alteration, and significant $\mathrm{Zn}$ and $\mathrm{Cu}$ values. Commonly asso- ciated with tholeiitic to calc-alkaline marine volcanic rocks and immature sedimentary and volcaniclastic rocks, these deposits are similar to metalliferous hydrothermal deposits in a number of failed or intracrustal rifts as seen in the massive sulfide ores of the Hokuroku district, north of Odate, Japan (Ohmoto and Skinner, 1983). Banded iron formation and rare gold occurrences have also been reported from the Hillabee Greenstone (Stow and Tull, 1982).

\section{ORDOVICIAN TECTONICS OF THE SOUTHERN APPALACHIANS}

A growing body of evidence strongly suggests that rocks within the Dahlonega gold belt, Ashland-Wedowee-Emuckfaw belt, Opelika Complex, and Brevard fault zone formed, at least in part, within an Ordovician suprasubduction system receiving mafic-felsic volcanic material from nearby effusive-explosive eruptive centers, sedimentary input from reworking of these volcanic units, as well as a relatively proximal Grenville-aged terrane, and intrusion of mafic-felsic magmatic bodies. Stratigraphic correlation between these regions (Fig. 13), in addition to shared temporal and geochemical characteristics strongly supports their formation within a single (or linked) extensional basin. Using the characteristics of these rocks, in addition to modern tectonic analogues in the western Pacific, we present a model that can account for the observed characteristics in each of these lithotectonic regions.

\section{Tectonic Models of Taconic Orogenesis}

The Ordovician Taconic orogeny of eastern North America was among the world's first ancient orogens to be modeled within a modern plate tectonic context. Early models of the orogen proposed B-type subduction of Iapetus oceanic crust (i.e., accretionary orogen) beneath the Laurentian passive margin (Bird and Dewey, 1970; Hatcher, 1972). However, as critical tectonic elements were examined in more detail, the northern Appalachians of eastern New York, New England, and the Canadian Maritimes were soon being modeled using the opposite subduction polarity (i.e., A-type, collisional orogen), where orogenesis and emplacement of an exotic arc(s) were explained by partial subduction of the Laurentian passive margin beneath the exotic arc(s) (Chapple, 1973; Robinson and Hall, 1980; Rowley and Kidd, 1981; Stanley and Ratcliffe, 1983, 1985). Although more recent work suggests that subsequent orogenic events may have resulted from accretionary-type orogens (e.g., Karabinos et al., 1998; Waldron and van Staal, 2001; van Staal et al., 2007; Zagorevski et al., 2006), a collisional orogenic model for initial phases of the Taconic orogeny in the northern Appalachians remains the most widely accepted model and has been extrapolated into the central and southern Appalachians (e.g., Shanmugam and Lash, 1982; Hatcher, 1987, 2005; Higgins et al., 1988; Drake et al., 1989; Hatcher et al., 2007; McClellan et al., 2007), where it has been commonly cited to explain initial phases of Appalachian 


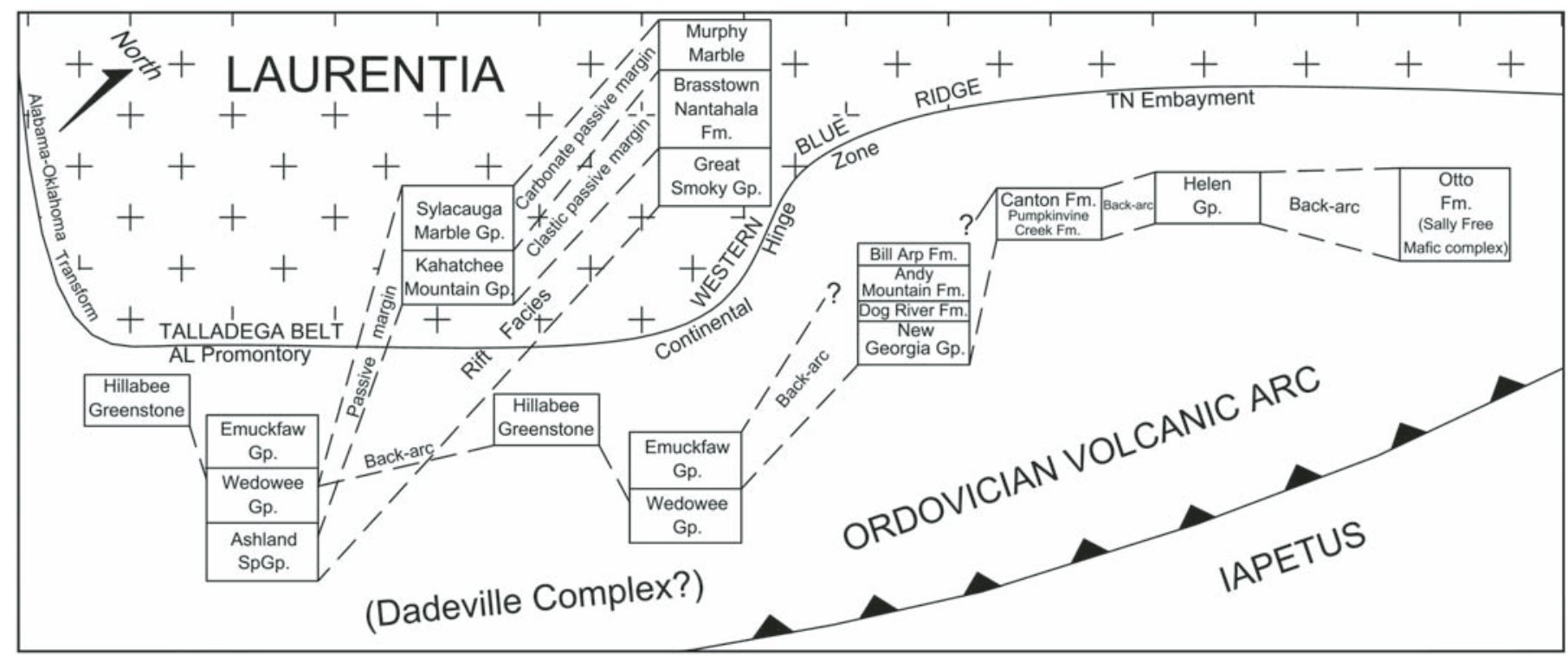

Figure 13. Inferred palinspastic location and correlation of Cambrian-Ordovician stratigraphy and tectonic elements in the southern Appalachians.

mountain-building and Ordovician paleotectonic reconstructions (e.g., Mac Niocaill et al., 1997; Cocks and Torsvik, 2002).

\section{Collisional Orogenesis}

In the southern Appalachians, the geometry of assembled lithotectonic elements and timing constraints sharply contrasts with certain aspects of collisional orogens. For example, in modern A-type subduction settings - including northward subduction of the Australian margin in Timor and western Papua New Guinea (Harris et al., 1998; Audley Charles, 2004; Cloos et al., 2005; Harris, 2006; Keep and Haig, 2010) and eastward subduction of the Asian margin in Taiwan (Huang et al., 2006)—commonalities to each of these collisional orogenies include separation of the arc from the foreland by a forearc and accretionary prism, uplift of the accretionary prism during initial subduction of the continental margin, and rapid waning of arc volcanism following margin subduction. The Ordovician history of the southern Appalachians, however, includes a number of critical elements that contrast sharply with well-studied Cenozoic collisional orogens. These include (1) the duration and tectonic setting of suprasubduction activity, (2) the absence of an arc sensu stricto, (3) the absence of Taconic allochthons, (4) the paucity (lack?) of Taconic thrust faults, (5) the absence of a forearc and accretionary prism between "accreted" arc terranes and the Laurentian margin, (6) suprasubduction affinity (back-arc) sequences built on or emplaced directly on top of rocks of the Laurentian shelfslope-rise, and (7) evidence for the development of significant extensional basins sourcing sediment from both the Laurentian margin and an adjacent arc terrane, while at the same time receiving significant input of volcanic material. Instead, the palinspastic position of extensive Lower-Middle Ordovician back-arc affin- ity volcanic and sedimentary sequences in the WEDB built atop Neoproterozoic-Cambrian Laurentian rifted margin rocks indicates B-type subduction of Iapetus oceanic lithosphere beneath the Laurentian plate.

\section{Accretionary Orogenesis}

Although inconsistent with the features typical of collisional orogens, the geologic history of the southern Appalachians is consistent with the development of extensional and contractional phases of an accretionary orogen similar to those associated with opening of the Sea of Japan (East Sea) during the Cenozoic (Yoon et al., 2014) and the Lachlan orogen during the Paleozoic (Gray and Foster, 2004). Orogenic elements that develop on the overriding plate during B-type subduction of oceanic lithosphere (accretionary orogenesis) commonly include (1) rocks identified as fragments of oceanic crust (ophiolitic 'slivers') with back-arc basin geochemical signatures (e.g., Lachlan orogen, Gray and Foster, 2004); (2) extensive turbidite deposits that are generally devoid of arc-derived lithic fragments (Cawood et al., 2009); (3) emplacement of back-arc basement and cover sequences atop adjacent pre-rift terranes during contractional phases (e.g., New Caledonia, Cluzel et al., 2001); and (4) intrusion of back-arc basement and sedimentary cover by syn- and post-tectonic granitoids (e.g., Lachlan orogen, Gray and Foster, 2004; Yukon-Tanana terrane, Piercey et al., 2001). Significantly, the final assembly of terranes within an accretionary orogen along a continental margin generally consists of back-arc rocks structurally between rocks of the adjacent continent and an outboard arc-forearc-accretionary prism-although intrabasinal subduction of back-arc oceanic crust can complicate this geometry (Cluzel et al., 2001; Gray and Foster, 2004; Cawood et al., 2009). 
The collective geologic data set from the southern Appalachians indicates that rocks within the WEDB: (1) were built directly atop portions of the Neoproterozoic-Cambrian Laurentian continental margin (Ashland Supergroup); (2) formed in an extensional environment capable of producing significant volumes of mafic volcanic material through decompression melting (e.g., Hillabee Greenstone, Pumpkinvine Creek Formation, Sally Free mafic complex, New Georgia Group; (3) formed in a setting in which Ordovician granitic magmas could incorporate Grenville-aged crustal components (e.g., Hillabee metadacites, Galts Ferry gneiss, Cane Creek gneiss); (4) formed in an extensional setting capable of receiving sedimentary input from both Ordovician volcanic units and Grenville crustal sources (Wedowee, Emuckfaw, and New Georgia Groups); (5) formed in a tectonic setting proximal to the Paleozoic Laurentian margin such that volcanic suites (Hillabee Greenstone) could be emplaced on top of younger shelf rocks with little evidence for synchronous or prior deformation; (6) formed in a setting that allowed them to be emplaced atop Laurentian marginal sequences without the presence of an intervening arc, forearc, or accretionary prism. The only tectonic model capable of accommodating all of the observed characteristics of the WEDB is one in which an Ordovician back-arc basin developed along the seaward margin of the Laurentian plate immediately outboard of the continental hinge zone (Holm-Denoma, 2006; Barineau, 2009; Holm-Denoma and Das, 2010; Tull et al., 2007, 2014). This accretionary orogenic setting contrasts with models of collisional orogenesis in the northern and central Appalachians, and suggests that one or more significant transforms between the two ends of the orogen accommodated a reversal of subduction polarity, not unlike that observed along the Alpine fault of New Zealand (Tull et al., 2014).

\section{POTENTIAL LINKS WITH OTHER SOUTHERN APPALACHIAN LITHOTECTONIC SUITES}

In addition to the linkages established above for rocks within the WEDB, a number of other southern Appalachian lithotectonic suites contain rocks that may be part of, or that were influenced by, this Laurentian plate back-arc basin.

\section{Poor Mountain Amphibolite}

The Poor Mountain Amphibolite on the west flank of the Inner Piedmont, eastern Tugaloo terrane of Hatcher et al. (2007), has been correlated with the Jacksons Gap Group in the Brevard fault zone (Davis, 1993). Rocks of the Poor Mountain sequence are dominated by a basal amphibolite grading upward into the quartzofeldspathic Poor Mountain Quartzite and local marble. Trace element geochemistry suggests a volcanic arc or MORB setting for the amphibolite sequence (Davis, 1993; Yanagihara, 1994; Bream, 2003; Kalbas et al., 2002), similar to other units within the WEDB. The Poor Mountain Quartzite, interpreted as a probable felsic metatuff, yields U-Pb zircon ages of $459 \pm 4 \mathrm{Ma}$ and $445 \pm 4 \mathrm{Ma}$ in two data subsets (Bream, 2003). A number of researchers have interpreted the Poor Mountain as having formed in a suprasubduction (arc or back-arc) setting (Davis, 1993; Bream, 2003; Hatcher et al., 2007; Merschat, 2009). If rocks of the Poor Mountain are, in fact, part of the WEDB, they would comprise the youngest recognized units of this back-arc basin.

\section{Central Blue Ridge}

Of limited regional extent, the central Blue Ridge of Georgia and North Carolina (Cowrock-Cartoogechaye terranes) is often interpreted as the Blue Ridge Taconic "orogenic core" and contains a number of metamorphosed mafic-ultramafic complexes, one of the only suprasubduction plutons of intermediate composition (Persimmon Creek Gneiss) found in the southern Appalachians (Meschter-McDowell et al., 2002), limited Grenville basement, and extensive sequences of metasedimentary rocks (Hatcher et al., 2007). Some workers have interpreted block-inmatrix structures common to the central Blue Ridge as pointing to origination within a subduction complex mélange (Raymond et al., 1989), an idea supported by trace element analysis, which suggests the mafic-ultramafic complexes represent ophiolitic slivers (Swanson et al., 2005). Other workers (Settles, 2002; Hatcher et al., 2007; Merschat et al., 2010) have suggested that the central Blue Ridge terranes represent the structurally highest thrust sheets west of the Chattahoochee fault and, importantly, must be palinspastically restored to a position southeast of the Dahlonega gold belt, placing them outboard of the WEDB (Fig. 14).

\section{Dadeville Complex}

The Dadeville Complex is a thick ( $>6 \mathrm{~km}$ ), extensive metavolcanic and metaplutonic complex with minor metasedimentary rocks, located in the core of the map-scale Tallassee synform. The complex is fault bounded by the Stonewall Line on the south and southeast and against the Jacksons Gap Group of the Brevard fault zone on the northwest along the Katy Creek fault (Bentley and Neathery, 1970). This sparsely studied complex resides as a synformal klippe above rocks of the WEDB and must have originated to the southeast somewhere outboard of the Pine Mountain belt. The structurally lowest, thickest (structural thickness $>5 \mathrm{~km}$ ), and spatially most extensive unit ( $70 \%$ of the complex's nonintrusive rocks) is the Ropes Creek Amphibolite and its northwestern equivalent, the Waresville Formation and/ or Amphibolite (Bentley and Neathery, 1970; Stow et al., 1984). The bulk of the Ropes Creek-Waresville unit consists of metamorphosed mafic and intermediate tuffs (Bentley and Neathery, 1970; Sears et al., 1981) and tholeiitic basalts and their differentiates (Neilson and Stow, 1986). These metamafic units lack basement, but are intercalated with intermediate (andesitic and/or dacitic) gneisses (Waverly Gneiss), minor pelitic metasedimentary rocks, metagraywacke (metaturbidite?), spessartine and/or magnetite quartzite (metachert?), and calc-silicate gneiss (Clark, 1973; Brown and Cook, 1981; Sears et al., 1981). Locally, the 


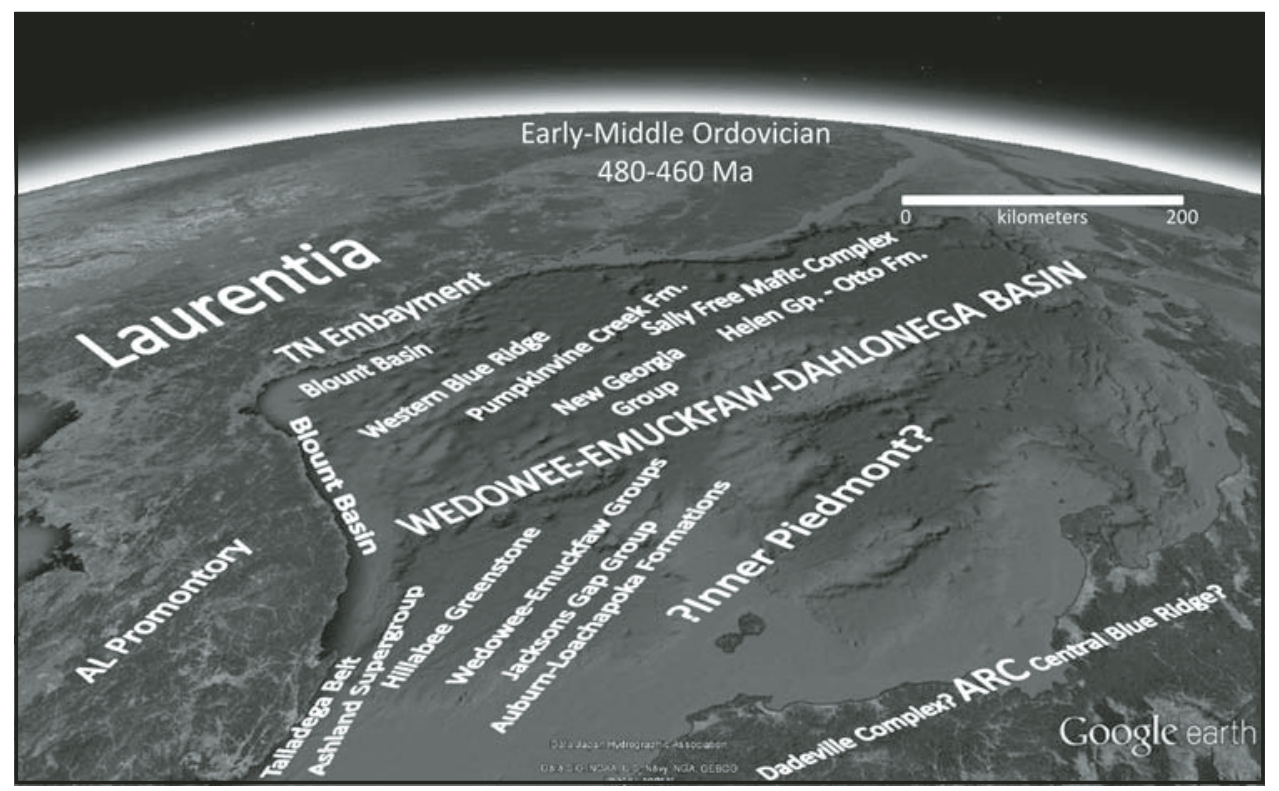

Figure 14. Relative palinspastic positions of WEDB lithotectonic elements as they might have appeared during the Early-Middle Ordovician, superposed atop the modern Sea of Japan back-arc basin. Background image courtesy of Google Earth.

unit contains apparent mafic and ultramafic olistostromes, potentially representing ophiolitic mélange (Neathery, 1968; Sears et al., 1981). Based on a general lack of abundant metasedimentary rocks in the section, Bentley and Neathery (1970) suggested that most of the volcanism was subaerial, but Spell and Norrell (1990) identified relict pillow structures in the unit near Woolsey, Georgia. The Ropes Creek-Waresville metabasalts have enriched (E)-MORB geochemical signatures, and have been interpreted as forming in an oceanic or back-arc rift environment (Stow et al., 1984; Spell and Norrell, 1990). In the core of the Tallassee synform, the Ropes Creek Formation is structurally overlain by the uppermost unit of the Dadeville Complex, the Agricola Schist (Sears et al., 1981), a >1-km-thick sequence of interbedded pelitic schist, thin metagraywacke, and amphibolite. The Ropes Creek and Agricola units have been intruded by several suites of felsic (metatonalite and metagranite) and mafic (metanorite, metagabbro, and metaorthopyroxenite) plutonic rocks (Bentley and Neathery, 1970; Sears et al., 1981; Stow et al., 1984; Neilson and Stow, 1986; Spell and Norrell, 1990; Steltenpohl et al., 1990), comprising $>50 \%$ of the complex. The age of these rocks is largely unconstrained, as the only dated unit within the Dadeville Complex is the Franklin Gneiss, which intrudes the Ropes Creek Formation and Agricola Schist along the northwest flank of the complex in Georgia, apparently extending into Alabama as the Rock Mills Granite Gneiss-Chattasofka Creek Gneiss (Neilson, 1983; Raymond et al., 1988). Seal and Kish (1990) reported a $462 \pm 4 \mathrm{Ma} \mathrm{Rb-Sr}$ whole-rock isochron for the Franklin Gneiss, which may constrain the country rocks as being Middle Ordovician or older. Less equivocal ages for these units await the application of modern, single grain ion microprobe techniques to metaigneous rocks of the Dadeville. Neilson and Stow (1986) suggested that mafic and ultramafic plutonic rocks of the Dadeville Complex formed during two separate periods of intrusion.
The first suite, the Doss Mountain, consists of metanorite and metaorthopyroxenite cumulates, whereas the Slaughters suite consists of metagabbro (Neilson and Stow, 1986). Abundant geochemical evidence strongly indicates that the protoliths of both the Doss Mountain and Slaughters suites formed within a volcanic arc environment (Stow et al., 1984; Neilson and Stow, 1986). Following Neoacadian or early Alleghanian metamorphism (Steltenpohl and Kunk, 1993), the Dadeville Complex was detached from its basement along a ductile shear zone, now represented locally by the Stonewall Line (Keefer, 1992). A simple retrodeformation of the Dadeville Complex involving unfolding of the Tallassee synform and moving the complex southeastward off of the structurally underlying WEDB implies a minimum displacement along the basal detachment of $\sim 50 \mathrm{~km}$. Ductile deformation within the Brevard fault zone in Alabama, associated with an oblique thrust-right slip duplex containing the Jacksons Gap Group, where the Katy Creek fault is the roof thrust, is interpreted as being associated with emplacement of the Dadeville Complex onto units of the WEDB (Sterling, 2006). The basal Dadeville Complex detachment appears to climb up-section to the northwest (in the direction of displacement) from the structural base of the Ropes Creek-Waresville Formation in the southeast, to near the base of the Agricola Schist on the northwest. The tholeiitic E-MORB geochemical signature of the thick pile of metabasalt and associated lesser intermediate metavolcanic rocks suggests that these country rocks formed within either an oceanic or backarc rift environment (Stow et al., 1984; Spell and Norrell, 1990) that, unlike the WEDB, received little sediment input. The limited age constraints (Franklin Gneiss) for the Dadeville Complex present the possibility that it formed prior to $462 \pm 4 \mathrm{Ma}$ and, therefore, could be similar in age to sequences in the WEDB. Coupled with interpretation of the Dadeville Complex as containing metaigneous rocks of volcanic arc affinity, it is possible 
that the Dadeville represents part of an Early-Middle Ordovician volcanic arc (Fig. 14) paired with the WEDB back-arc (Tull et al., 2014).

\section{Taconic Clastic Wedge (Blount Basin)}

The southern Appalachian foreland's Blount basin has traditionally been interpreted as the Middle-Late Ordovician Taconic synorogenic clastic wedge. The onset of deposition within this basin occurs during the Middle Ordovician (Darriwilian stage, Cohen et al., 2013) and is marked by cratonward uplift of the Cambrian-Ordovician carbonate platform (post-Knox unconformity) and seaward deposition of deep-water black shales ( $D$. murchisoni graptolite zone) along the Alabama promontory, with subsequent sedimentation progressing into the foreland and northeast toward the Tennessee embayment into the early Late Ordovician (Bayona and Thomas, 2003, 2006). In addition to the $>2.5-\mathrm{km}$-thick sequence of mud, silt, and sand in its thickest preserved parts, the Blount basin includes volcanic ash sequences (k-bentonites) from nearby silicic eruptive centers. The oldest of these, near the base of the Blount sequence (Shanmugam and Walker, 1980; Kolata et al., 1996; Bayona and Thomas, 2006), is Darriwillian in age, similar to the age of bimodal volcanic suites in the WEDB (e.g., Pumpkinvine Creek Formation). The youngest and most extensive of the k-bentonites near the top of the Blount sequence, the $448 \pm 2$ Ma Millbrig and $449 \pm 2.3 \mathrm{Ma}$ Deicke (Min et al., 2001), thicken toward a palinspastic location between Alabama and Pennsylvania (Kolata et al., 1998), suggesting they originated in the vicinity of the WEDB. Additionally, isotopic evidence for the Deicke and Millbrig k-bentonites suggests they formed in a volcanic arc influenced by continental crust (Huff et al., 1992; Coakley and Gurnis, 1995; Kolata et al., 1996, 1998; Haynes et al., 2011; Samson et al., 1989). Although formation of the Blount basin in the southern Appalachians has been modeled as a typical foreland basin forming in advance of a developing thrust belt due to subduction of the Laurentian margin beneath an exotic island arc (Keller, 1977; Shanmugam and Walker, 1978; Shanmugam and Lash, 1982; Quinlan and Beaumont, 1984; Beaumont et al., 1988; Hatcher, 1989; Ettensohn, 2004; Diecchio, 1993; Finney et al., 1996), certain characteristics of the basin contrast with typical models of foreland basin evolution and with Ordovician clastic wedges in the central-northern Appalachians (e.g., Martinsburg). First, source rocks of the Blount basin consisted exclusively of Laurentian margin, shallow water sedimentary rocks and possibly basement igneous and metamorphic rocks (Kellberg and Grant, 1956; Cressler, 1970; Bayona and Thomas, 2003), but the sediments lack evidence or detrital contributions from volcanic or deep-water sedimentary sources (Mack, 1985), or Taconic-age detrital zircons (Merschat et al., 2010). Additionally, there is no evidence that the advancing "thrust sheet" modeled for the Taconic orogeny in the southern Appalachians ever reached the Blount basin, nor are Ordovician thrust faults identified along the margins of the Blount basindespite evidence that the Blountian "highlands" must have been proximal to the basin (Shanmugam and Lash, 1982; Hatcher, 1989; Bayona and Thomas, 2006). In fact, thrust sheets east of the Blount, which would have been closer to the orogenic hinterland, show no evidence for significant deformation or erosional breaching during the Ordovician (Tull and Barineau, 2014). The presence of the WEDB immediately seaward of the Blount basin, the coeval nature of sedimentation in both basins, and evidence that both were affected by similarly aged silicic volcanic systems suggests a genetic relationship. We suggest that the Blount clastic wedge is better modeled as forming in a retroarc basin cratonward of the WEDB. In this model, the Blount basin developed due to inversion of Neoproterozoic rift-related faults, similar to models of intrabasinal uplift proposed by Bayona and Thomas (2003, 2006).

\section{PHASES OF SOUTHERN APPALACHIAN TACONIAN OROGENESIS}

Igneous activity, metamorphism, and foreland basin deposition associated with the southern Appalachian Taconic orogeny can be best explained in the context of B-type subduction of oceanic lithosphere beneath the early Paleozoic Laurentian plate and three extensional-contractional orogenic phases that affected rocks of the Laurentian margin, including Ordovician sedimentary-igneous sequences. The numerous Early to Late Ordovician radiometric ages from Neoproterozoic Ocoee Supergroup rocks in the western Blue Ridge, cited as defining peak Taconic metamorphism (e.g., Moecher et al., 2005; Corrie and Kohn, 2007), can be attributed to extension-contraction phases associated with this accretionary orogen, which also accounts for the geologic history of the Taconic foreland basin in the southern Appalachians (Blount wedge) and the arrangement of lithotectonic belts discussed herein. Although the Taconic orogeny of the northern Appalachians has been similarly divided into different tectonic phases, events in the southern Appalachians differ in both their timing and tectonic setting and suggest that the two ends of the orogen cannot be explained with a single orogenic model.

\section{Pre-Orogenesis and Subduction Initiation}

Following rifting along the Iapetus margin of Laurentia, ca. $570 \mathrm{Ma}$ (Aleinikoff et al., 1995), and development of a passive trailing margin (Thomas, 1991), the presence of suprasubduction igneous activity indicates subduction initiation no later than Early Ordovician (ca. 482 Ma Sally Free mafic complex). In the western Pacific, normal arc magmatism seems to follow subduction initiation by 7-8 m.y. (Ishizuka et al., 2011), and observations and models suggest back-arc volcanism develops within a few tens of millions of years following subduction initiation in suprasubduction systems that have back-arcs (Hall et al., 2003; Gurnis et al., 2004; Stern et al., 2006). We suggest that subduction began prior to development of the 480-460 Ma Blue Ridge back-arc rocks, but suprasubduction igneous activity from the latest Cambrian-earliest Ordovician (ca. 500-480 Ma) may be 
limited because: (1) it produced limited arc activity resulting from trench-oblique subduction, or (2) it has been largely overprinted by younger magmatic events. A number of southern Appalachian metaigneous bodies contain zircons that suggest a Late Cambrian inherited component, including the Middle to Late Ordovician Persimmon Creek Gneiss (489-510 Ma inheritance, Miller et al., 2000; Meschter-McDowell et al., 2002), Hillabee Greenstone (ca. 497 Ma inheritance, McClellan et al., 2007), and the Barlow Gneiss (ca. 490 Ma inheritance, Thomas, 2001). In the case of the Persimmon Creek Gneiss (Cowrock terrane), Miller et al. (2000) and Meschter-McDowell et al. (2002) suggest the older ages may be either the true age of the pluton, or might represent an earlier magmatic event prior to emplacement. We speculate that these Late Cambrian inherited ages may mark the earliest phases of magma generation along the Laurentian margin following subduction initiation outboard of the continental hinge zone (Barineau, 2009).

Interestingly, both detrital zircon and monazite ages also suggest a thermal event that affected the central Blue Ridge ca. 500 Ma. Miller et al. (1998) report U-Pb ion microprobe ages of $495 \pm 14 \mathrm{Ma}$ on zircon rims from rocks at Winding Stair Gap in the central Blue Ridge, interpreting this as the peak metamorphic age for the southern Appalachians. However, crystallization ages for metavolcanic suites in the WEDB (ca. 480-460 Ma), commonly interpreted as the major volcanic component of the Taconic "arc," make this interpretation untenable since they postdate the age assigned to peak metamorphism. However, a thermal pulse associated with subduction initiation along the Iapetus margin of Laurentia (Barineau, 2009) would explain the growth of metamorphic zircon during this time interval. Additionally, recent $\mathrm{U}-\mathrm{Th}-\mathrm{Pb}$ ages on monazite from Winding Stair Gap in the central Blue Ridge (El Shazly et al., 2011) suggests three phases of monazite growth based on zoned crystals-360.4 $\pm 5 \mathrm{Ma}, 438 \pm 5 \mathrm{Ma}$, and $509 \pm 14$ Ma. Because monazite can grow under both diagenetic and metamorphic conditions (Rasmussen et al., 2001; Evans et al., 2002), it has been used to provide insights into the geologic history of rocks that might be obscured by overprinting during younger thermal events. In this case, the ca. 509 Ma age seems to duplicate the zircon record of a Late Cambrian thermal event that might be associated with a subduction initiation event. This event must postdate rifting associated with the formation of Iapetus (i.e., ca. 570 Catoctin Formation), but predates both the Early-Middle Ordovician volcanism of the WEDB and the 470-460 Ma age of leucosomes interpreted as having developed during migmatization of rocks at Winding Stair Gap (Moecher et al., 2004; Anderson and Moecher, 2009). The combination of ca. 500 metamorphic zircon, monazite growth, and xenocrystic components in younger plutons suggests the potential for a Late Cambrian thermal pulse that affected a significant portion of the southern Appalachian Laurentian margin, but that has been obscured by subsequent tectonism.

Because early Paleozoic southern Appalachian suprasubduction plutonic-volcanic igneous rocks did not intrude rocks of the Laurentian shelf, and Ordovician plutons are associated with rocks interpreted as the Laurentian rifted-margin prism and younger back-arc basin (WEDB) or rocks interpreted as an accretionary prism-subduction complex (e.g., Cartoogechaye terrane), we argue that the locus of the subduction of Iapetus oceanic lithosphere was well outboard of the continental hinge zone, possibly in transitional crust at the continent-ocean boundary (Tull et al., 2007; Barineau, 2009).

\section{Taconic A}

\section{Early to Middle Ordovician Magmatism}

Following latest Cambrian subduction initiation, extension on the overriding Laurentian plate outboard of the continental margin resulted in formation of an extensive back-arc (Gillon, 2001; Barineau, 2009; Holm-Denoma and Das, 2010; Tull et al., 2014) extending $>400 \mathrm{~km}$ from the Alabama promontory, northeastward into the Tennessee embayment, and possibly farther, built on attenuated continental basement and rifted-margin cover (Iapetus-margin passive-margin) rocks. This back-arc extension phase is represented by rocks of the WEDB, and potentially rocks of the Poor Mountain Amphibolite in the western Inner Piedmont. The ca. 466 Ma Whiteside pluton (W. Tugaloo terrane, Miller et al., 2000)) would also be associated with this first phase of the southern Appalachian Taconic, as well as the Persimmon Creek Gneiss, which intrudes the Coweeta Group of the Cowrock terrane, depending on its inferred crystallization age (ca. 492 or 480 Ma, Miller et al., 2000; ca. 468 Ma, Meschter-McDowell et al., 2002; or ca. 456 Ma, Miller et al., 2006). It is possible that the Persimmon Creek Gneiss is a multiphase intrusion with magmatic ages that span multiple intervals of Ordovician tectonism. Although the Dadeville Complex in the Alabama Inner Piedmont is in a position that might make it a candidate for the Taconic arc, and additionally contains abundant metamorphosed mafic and intermediate composition igneous rocks (Tull et al., 2014), the lack of age constraints makes interpretation of it as the Taconic arc speculative.

A paired arc and back-arc built on the Laurentian margin would explain the current position of the WEDB back-arc rocks directly atop rocks of the Laurentian shelf (Tull et al., 2007, 2014). Arc rocks sensu stricto would have developed outboard and east of this extensive back-arc terrane and would have been rifted away from the Laurentian margin similar to the separation of basement from the Asian mainland during formation of the Sea of Japan (Kim et al., 2007; Yoon et al., 2014). This model for the initial phase of the Taconic orogeny would explain the position of rocks interpreted as an accretionary prism (parts of Cartoogechaye-Cowrock-W. Tugaloo terranes, Raymond et al., 1989; Hatcher et al., 2007; Anderson and Moecher, 2009) and arc plutons (Persimmon Creek Gneiss-Cowrock terrane; Whiteside pluton-W. Tugaloo terrane) that must be palinspastically restored to a position outboard of the Dahlonega gold belt (Hatcher et al., 2007), currently atop units of the WEDB. 


\section{Early to Middle Ordovician Sedimentation}

Initiation of back-arc extension is controlled by the age of subducting oceanic lithosphere ( $>55$ m.y.), the intermediate dip angle of the subducting plate $\left(>30^{\circ}\right)$, and the absolute motion of the overriding plate (away from the trench) - at which point rollback of the subducting slab drives further extension on the overriding plate (Sdrolias and Müller, 2006). The post-Knox unconformity and drowning of the Alabama promontory carbonate platform, both Late Middle Ordovician events (Darriwilian), are coeval with back-arc activity (e.g., Pumpkinvine Creek) in the WEDB. Bayona and Thomas (2003) note that intraplate uplifts associated with basement fault reactivation provide a better explanation for abrupt truncation of the Knox Group and irregular deposition of carbonate in the distal foreland than traditional interpretations of a migrating Taconic foredeep resulting from A-type subduction (Shanmugam and Lash, 1982; Ettensohn, 2004). The oldest portions of the Blount basin may be associated with this largely extensional regime (Fig. 14).

\section{Early to Middle Ordovician Metamorphism}

Zircons extracted from leucosomes in migmatitic gneiss at Winding Stair Gap and Dellwood (Cartoogechaye terrane) suggest 470-460 Ma crystallization ages (Moecher et al., 2004; Anderson and Moecher, 2009) coeval with crystallization ages for back-arc rocks in the WEDB. These metamorphic ages can be attributed to tectonic processes associated with accretionary orogenesis. Underplating of attenuated lithosphere by mafic magma in a back-arc is capable of producing the amphibolite to granulite (intermediate pressure type) facies metamorphism observed in rocks of the Blue Ridge. Granulites from accretionary orogenic belts in Japan (Hidaka metamorphic belt, Kemp et al., 2007) and New Zealand (Lachlan-equivalent Tuhua orogen, Gibson, 1992) developed under temperatures and pressures similar to those cited for some granulites in the Blue Ridge (e.g., Winding Stair Gap, $\sim 850^{\circ} \mathrm{C} / \sim 8 \mathrm{~kb}$; Moecher et al., 2004). Initial extension (ca. $480 \mathrm{Ma}$ ) in the back-arc region of the orogen, with associated magmatic underplating, would mark the earliest phases of metamorphism and may be responsible for the largely static nature of Blue Ridge Taconic metamorphism (Clemons and Moecher, 2009), with subsequent subduction of continental material - either in the outboard Iapetus subduction zone or during subduction of back-arc lithosphere-generating the younger eclogites (ca. $460 \mathrm{Ma}$ ) during the second phase of the southern Appalachian Taconic (see below).

\section{Taconic B}

\section{Early Late Ordovician Metamorphism and Magmatism}

During the second phase of the southern Appalachian Taconic orogeny, contraction on the overriding plate resulted in formation of eclogites (e.g., Lick Ridge eclogite, W. Tugaloo terrane), which developed during subduction of lithosphere at the plate interface between Laurentia and Iapetus, or alternatively, during subduction of back-arc lithosphere within the WEDB due to compression of the overriding plate. Anderson and Moecher (2009) argue for medium-temperature high-pressure metamorphism in the Western Tugaloo terrane (Lick Ridge and Boone eclogites) as a result of subduction of continental crust (subduction erosion) at ca. $459 \mathrm{Ma}$ (Miller et al., 2006). A $449 \pm 2 \mathrm{Ma}$ ${ }^{40} \mathrm{Ar}{ }^{\beta 9} \mathrm{Ar}$ hornblende age from rocks in the same area suggests cooling due to exhumation following peak metamorphism, while Mesoproterozoic cores from zircons in the same rocks indicate involvement of Grenville-aged crust in this event (Kunk et al., 2006; Anderson and Moecher, 2009). Monazite ages from rocks in the Great Smoky Mountains suggest a latest Ordovician (ca. $450 \mathrm{Ma}$ ) thermal event in the western Blue Ridge (Corrie and Kohn, 2007). Collectively, this suggests a $\sim 10$ m.y. contractional phase beginning at ca. $460 \mathrm{Ma}$, which marks the end of extensive back-arc volcanism in the WEDB. Evidence for southern Appalachian Taconic metamorphism is largely confined to the Tennessee embayment, with deformational effects limited to mild flexure of the carbonate platform on the distal margin of the Alabama promontory's Talladega belt (Tull, 1998). The restricted metamorphism and limited deformation associated with Taconic orogenesis may be associated with a subduction channel at the locus of the Tennessee embayment (Anderson and Moecher, 2009), or may be the result of lithosphere-scale strain partitioning in the thinner and weaker oceanic basement-cover sequences associated with the lower-plate rifted-margin geometry of the Tennessee embayment (Thomas, 1991). Igneous activity, including the ca. 458 Villa Rica Gneiss (Thomas, 2001), did not wholly cease during this phase, but was restricted to silicic magmatism, similar to that observed in the Lachlan orogen during contractional phases of accretionary orogenesis (Collins, 2002). Similarly, contraction in the southern portion of the Sea of Japan (East Sea) following initial Late Oligocene-Early Miocene extension resulted in waning of volcanic activity (Yoon et al., 2014), in contrast to the cessation of volcanic activity observed in backarcs during closure associated with arc-continent collision (e.g., Banda Arc, Honthaas et al., 1998).

\section{Early Late Ordovician Sedimentation}

Following destabilization of the passive-margin carbonate platform during Taconic A, deepening of the Blount basin and deposition of black shales (Bayona and Thomas, 2003) were likely caused by contraction of the back-arc and reverse faulting associated with inversion of inherited extensional faults formed during Laurentian rifting and/or younger back-arc extension during Taconic A. Contractional phases in back-arc settings can be driven by subduction of buoyant lithosphere (Collins, 2002), a low dip angle $\left(<30^{\circ}\right)$ of the subducting slab (Lallemand et al., 2005 ), or the mechanics of the contact between the overriding and subducting plate (DeFranco et al., 2008). In the case of the southern Appalachian Taconic orogeny, inferred loading of the foreland basin correlates well with the end of back-arc volcanism (ca. $460 \mathrm{Ma}$ ) and subduction of continental elements to produce eclogites of the eastern Blue Ridge (Miller et al., 2006; Anderson and Moecher, 2009). We suggest that deposition of the foreland 
Blount wedge might be attributed to both the effects of backarc extension prior to $460 \mathrm{Ma}$ and compression on the overriding plate at ca. $460 \mathrm{Ma}$. Contraction within the back-arc region, however, was not sufficient to emplace Taconic allochthons onto the craton, accounting for the paucity of Taconic-aged thrust faults. In the southern Sea of Japan (East Sea), fault-bounded grabens and half-grabens along the western margin of the Ulleng basin (e.g., Hupo basin), adjacent to the Asian mainland, contain sediment derived from basement uplifts and cover that forms wedgeshaped sedimentary packages (Yoon et al., 2014). In this case, inversion of basement faults and uplift of the Hupo bank was coeval with contraction in the back-arc, resulting in deposition of Hupo basin sediments in the latest Miocene (Yoon et al., 2014). We consider the Hupo basin an excellent analogue for the Ordovician Blount basin (Fig. 14) due to similarities between their geometry, sedimentary influences and position relative to their respective continental margins during formation.

\section{Taconic C_Latest Ordovician}

Following initiation of the ca. 460 Ma contractional phase of the Taconic orogeny in the southern Appalachians, a resumption of extension on the overriding plate resulted in continued backarc extension, and is represented by the $449.8 \pm 2.3$ Ma Deicke and 448.0 \pm 2.0 Ma Millbrig k-bentonites (Min et al., 2001), the 447.6 + 5.4 Ma Henderson Gneiss (Moecher et al., 2011), $444 \pm$ 11 Ma Kennesaw granitoid (Bream, 2003), and potentially the $445 \pm 4$ Ma component of the Poor Mountain Formation (Bream, 2003). Importantly, plutonic activity generally migrates to the southeast and outboard of the Laurentian margin and rocks that formed during the first two phases of the southern Appalachian Taconic, similar to rocks of the Lachlan orogen in southeastern Australia (Gray and Foster, 2004), the Ulleung basin in the Sea of Japan (Yoon et al., 2014), and typical of tectonic 'switching' events noted in accretionary orogens (Collins, 2002).

In fact, the Lachlan orogen seems to provide an excellent analogue for Ordovician tectonics along the southeastern Laurentian margin. The Lachlan consists of a western metamorphic belt, adjacent to the Cambrian Australian craton, in which the earliest back-arc volcanic rocks are generally exposed in the hanging walls of major reverse faults that soled at the base of turbidite or mafic sequences. Progressively younger portions of the back-arc formed more outboard (east) of the Australian craton and include a diverse group of suprasubduction rocks and younger S-type plutons. The youngest arc rocks occur in the easternmost part of the orogen and formed during a period of prolonged lithospheric extension. Periods of contraction resulted in major reverse faulting, deformation, and synorogenic sedimentation, whereas periods of extension resulted in mafic and felsic volcanism and the formation of younger rift basins floored by oceanic lithosphere outboard of older portions of the orogen. Extensional faults were commonly reactivated (inverted) during contractional phases and exhumed deep-seated metamorphic rocks, while partial subduction of lithosphere within the back-arc resulted in subduction complexes complete with low-temperature high-pressure-bearing mélange. Although the Lachlan orogen can be loosely confined to two major tectonic episodes, time transgressive and localized orogenic events occur between these major events, complicating the magmatic and metamorphic history of the orogen (O'Halloran and Cas, 1995; Gray and Foster, 1997, 1998; Foster and Gray, 2000; Fergusson, 2003). The timing of tectonic events and arrangement of lithotectonic terranes in the Lachlan share many features with the lower Paleozoic history and lithotectonic elements of the southern Appalachians.

\section{CONCLUSIONS}

A number of Ordovician lithotectonic terranes in the southern Appalachians (Ashland-Wedowee-Emuckfaw belt, Dahlonega gold belt, Opelika Complex, Jacksons Gap Group) have historically been considered to be disparate suites of rock that developed in distinct geologic settings. Although some links between these terranes have been proposed, we suggest that they formed in an Ordovician back-arc basin immediately outboard of the continental hinge zone on the seaward edge of the Laurentian plate (Figs. 13 and 14). These sequences of the WEDB are linked by stratigraphic correlation, similarities in geochemical characteristics and age, and inferred tectonic setting. Identification of this extensive southern Appalachian back-arc basin has significant implications for tectonic models of Taconic orogenesis and contrasts sharply with models of collisional orogenesis for Ordovician tectonics in the northern Appalachians. Additionally, we suggest that the presence of this Ordovician back-arc basin resolves a number of puzzling aspects of the Taconic orogeny in the southern Appalachians. The presence of a northern Appalachian A-type subduction system coeval with a southern Appalachian B-type subduction system requires an Alpine fault-type transform boundary (i.e., New Zealand) between the two ends of the orogen during the latest Cambrian-earliest Ordovician accommodating a subduction polarity reversal. Further work is needed to constrain the location of the Taconic arc in the southern Appalachians and the position of the intervening transform separating the two ends of the orogen.

\section{ROAD LOG}

\section{Day 1-Friday, 20 March 2015}

\section{Chattanooga, Tennessee, to Cheaha Mountain State Park, Alabama}

We will depart from the main lobby of the hotel and convention center (The Chattanoogan, 1201 Broad St., Chattanooga, TN 37402) at 5:00 p.m. eastern daylight time (EDT). We should arrive at Cheaha Mountain State Park (2141 Bunker Loop, Delta, AL 36258) by 7:00 p.m. central daylight time (CDT) and will have a short presentation and geologic overview following check-in and dinner. 


\section{The Geology of Cheaha Mountain State Park}

Cheaha Mountain State Park (Fig. 15), the highest elevation in Alabama (2407 ft above sea level) is underlain by the Cheaha Quartzite of the Talladega Group, a Lower Devonian metasandstone and subordinate metaconglomerate sequence in the western Blue Ridge-equivalent Talladega belt. A detailed description of the geology of the Talladega belt is provided by Tull and Barineau (2012). The Cheaha and equivalent Butting Ram Quartzite are the main ridge-forming units of the Talladega Mountains (Fig. 15), which extend for $>150 \mathrm{~km}$ from the Coastal Plain near Jemison, Alabama, northeast to the Alabama-Georgia state line northwest of Hightower, Alabama. Mineralogically mature, quartz-rich metasandstones, low-angle planar crossbeds, and shallow-marine fauna suggest that the Butting Ram-Cheaha Quartzite represents a regionally extensive, near shoreface to shallow, open-marine deposit. Much of the quartz-rich Butting Ram-Cheaha Quartzite is probably reworked sediment from the underlying, mineralogically immature, Lay Dam Formation. Although the stratigraphic thickness of the Butting Ram-Cheaha Quartzite is less than $10 \mathrm{~m}$ in places, at Cheaha Mountain the sequence is nearly $400 \mathrm{~m}$ thick. Additionally, parasitic folding of fine-grained metasandstones, graphitic-micaceous metasandstones, and thinly bedded, micaceous quartzite ("papery" quartz- ite) in the uppermost Cheaha Quartzite and lower Erin Slate on the eastern dip-slope of Cheaha Mountain makes the exposed quartzite appear even thicker than its stratigraphic thickness would suggest at this location. An excellent view from the back porch of the park restaurant shows the sinuous trace of the ridge as it strikes south-southwest toward Bulls Gap east of Sylacauaga, Alabama. East-west-trending cross-folds (half-wavelength $>8 \mathrm{~km}$ ) produce broad-scale antiforms at Millerville and other areas of the Talladega belt, creating the gradual change in the trend of the quartzite ridge (south to southwest) as viewed from the western slope of the park. A large overturned synform-antiform produces a narrow infold (half-wavelength $>300 \mathrm{~m}$ ) of the overlying Erin Slate on the eastern slope of Cheaha Mountain. North of the park, the ridge at Cheaha Mountain abruptly terminates along the northern end of this doubly plunging structure, with phyllites and metagraywackes of the Lay Dam Formation wrapping around the northern end of this southerly plunging structure.

West of the Cheaha Mountain ridge, and structurallystratigraphically below the Cheaha Quartzite, the Lay Dam Formation at the base of the Talladega Group underlies much of the valley west of the park. Although dominated by easily weathered, variably chloritic and sericitic phyllites, thick metagraywacke sequences (micaceous and variably graphitic metaarkose) form

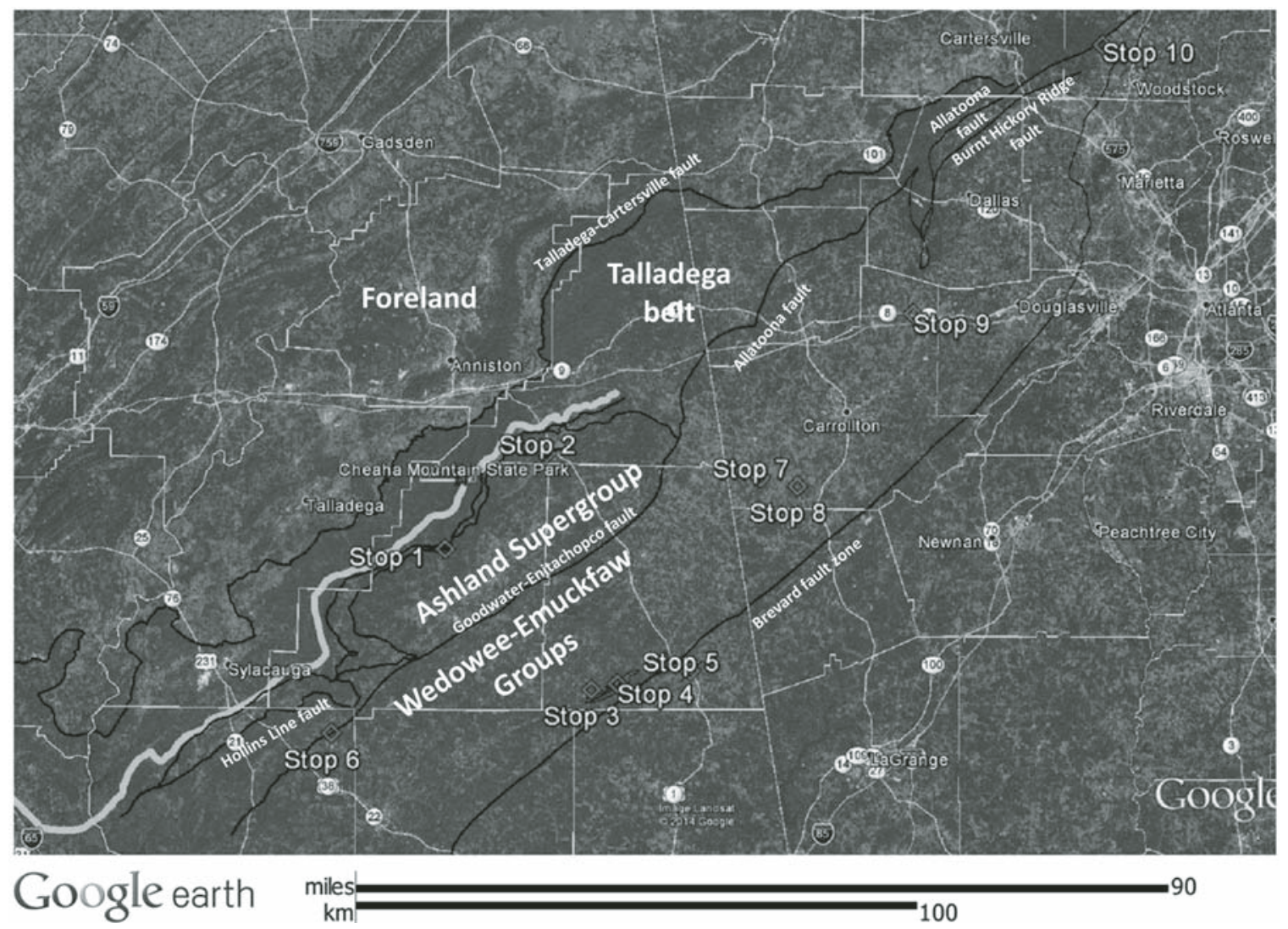

Figure 15. Regional map showing major faults (black lines) and stratigraphic packages, field trip stops, Cheaha Mountain State Park and the Talladega Mountains (bold gray line). 
many of the prominent ridges on the valley floor. On the eastern slope of the mountain, between the main quartzite ridge and the quartzite ridge where the Talladega Scenic Byway (AL S.R.-281) was constructed, quartzites of the Cheaha have been erosionally breached through a broad anticline, exposing phyllites and metagraywacke of the underlying Lay Dam Formation in a valley along the northeastern flank of Cheaha Mountain. Farther east, variably graphitic, chlorite-sericite phyllites and laminated micaceous quartzites of the uppermost Talladega Group Erin Slate lie above the Cheaha Quartzite. Correlative with the Jemison Chert to the southwest, papery quartzites of the Erin Slate hold up low ridges east of the massive Cheaha Quartzite ridge of the Talladega Mountains. Structurally above and east of the Erin Slate, chlorite-epidote-actinolite phyllites of the Middle Ordovician Hillabee Greenstone underlie broad valleys between rocks of the Laurentian shelf Talladega Group and eastern Blue Ridge (Ashland-Wedowee-Emuckfaw belt) allochthon. Rocks of the Hillabee Greenstone, a bimodal metavolcanic suite that formed in the Early-Middle Ordovician Wedowee-Emuckfaw-Dahlonega basin (WEDB), have been emplaced atop rocks of the Erin SlateJemison Chert along the premetamorphic Hillabee thrust, while rocks of the eastern Blue Ridge have been emplaced atop those of the Talladega belt along the postmetamorphic sole of the Hollins Line footwall thrust duplex.

\section{Day 2-Saturday, 21 March 2015}

\section{Talladega and Ashland-Wedowee-Emuckfaw Belts, Alabama (Eastern Blue Ridge)}

Participants should be ready to depart from the hotel by 8:30 a.m. CDT. The park restaurant adjacent to the hotel should open at 7:30 a.m. CDT and serves a breakfast buffet. The park store, immediately downhill from the restaurant, sells snacks, drinks, gifts and an assortment of toiletry items.

- From the main park entrance, turn right (south) on S.R.281 (Talladega Scenic Byway).

- After 6.7 miles, turn left on Adams Gap Road.

- After 1.6 miles, at the intersection of Adams Gap Road and Blue Ridge Road, continue straight on Blue Ridge Road.

- After 1.1 miles, turn left (east) on Clairmont Springs Road.

- After 2.3 miles, turn right (south) on Highland Road.

- Drive over the railroad crossing. Stop 1 is on the right side of Highland Road, 375 feet from its intersection with Clairmont Springs Road. Park in the dirt road entrance next to the steel gate. Caution! In wet weather, it can be difficult to get a vehicle back up the driveway to Highland Road.

\section{STOP 1 ( 1.5 h): Hillabee Greenstone, Hillabee Thrust Fault, Hollins Line Fault, and Poe Bridge Mountain Group at Pyriton, Alabama $\left(33.360865^{\circ} \mathrm{N}, 85.838692^{\circ} \mathrm{W}\right)$}

This stop is at the structural top of the Talladega belt, in the immediate footwall of the Hollins Line fault system. We will walk $\sim 0.5$ miles from the parking area outside the steel gate and cross a small creek to get to the exposures (Fig. 16). In this area, staurolite-bearing garnet-biotite-muscovite schists of the Neoproterozoic-Cambrian Poe Bridge Mountain Group (lower Ashland Supergroup) structurally overlie foliated and massive greenstone of the Middle Ordovician Hillabee Greenstone in the Talladega belt.

\section{Hillabee Greenstone Massive Sulfide Zone}

Pyrite from massive sulfide zones in the Hillabee Greenstone was mined at this location (Figs. 16 and 17) from prior to the Civil War until 1919. Total production from the Pyriton district was $\sim 100,000$ tons of pyrite. Ore from the Carpenter mine of the Alabama Sulfur Ore and Copper Company, one mile west of our location, is reported to have averaged $1.25 \% \mathrm{Cu}$ and $42 \%$ S (Lamont and Hastings, 1964). Other records (Geological Survey of Alabama, Adams, 1930) indicate ore ranging from 0.34 to 8.93\% Cu (average 2.19\%) and 17.4-44.9\% S (average 31.4\%). Ore samples from this mine (National Pyrite and Copper Company Mine) average several wt\% Cu. Lamont and Hastings (1964) reported a total of 6.4 million tons of inferred (3.95 million) and indicated ( 2.45 million) reserves at $18 \%$ pyrite ore extending down-dip as much as $215 \mathrm{~m}$. Tailings piles adjacent to this historic mine workings (National Pyrite and Copper Co. Mine) consist of metamorphosed pyrite-bearing mafic rocks, including foliated and non-foliated chlorite, albite epidote-clinozoisitezoisite, actinolite phyllites, and massive greenstones. The top and bottom of the sulfide zone occur in sharp contact with relatively barren host rock. The sulfide mineralogy is pyrite, chalcopyrite, sphalerite, galena, and trace amounts of pyrrhotite and covellite, in order of decreasing abundance. Only pyrite, chalcopyrite, and occasionally covellite are recognizable in hand specimen. The massive sulfide zones exposed here and at other locations in the WEDB are interpreted as synsedimentary seafloor, primitive exhalatives (Hutchinson, 1980; Stow and Tull, 1982). These strata-bound, type $1 \mathrm{Zn}-\mathrm{Cu}$ pyrite volcanogenic deposits show poor metal zoning, lack of wall rock alteration, and significant $\mathrm{Zn}$ and $\mathrm{Cu}$ values, typical of consuming plate margins, and are commonly associated with tholeiitic to calc-alkaline marine volcanics and immature sedimentary and volcaniclastic rocks (Stow and Tull, 1982). Similar metalliferous hydrothermal deposits have been identified in a number of failed or intracrustal rifts (e.g., Hokuroku district, Japan, Ohmoto and Skinner, 1983). The massive sulfide deposits exposed here are strongly associated with primitive deposits exhibiting a high $\mathrm{Zn}-\mathrm{Cu}$ content.

\section{Hollins Line Fault and Hillabee Thrust}

Walk east along the dirt track a short distance from the historic mine workings to observe the Hollins Line roof thrust in the hillside south of a small retaining pond. Here, lower greenschist facies rocks of the Hillabee Greenstone contrast sharply with middle-upper amphibolite facies rocks of the lower Ashland Supergroup across the Hollins Line fault. Although significant weathering of rocks on either side of the Hollins Line typically 


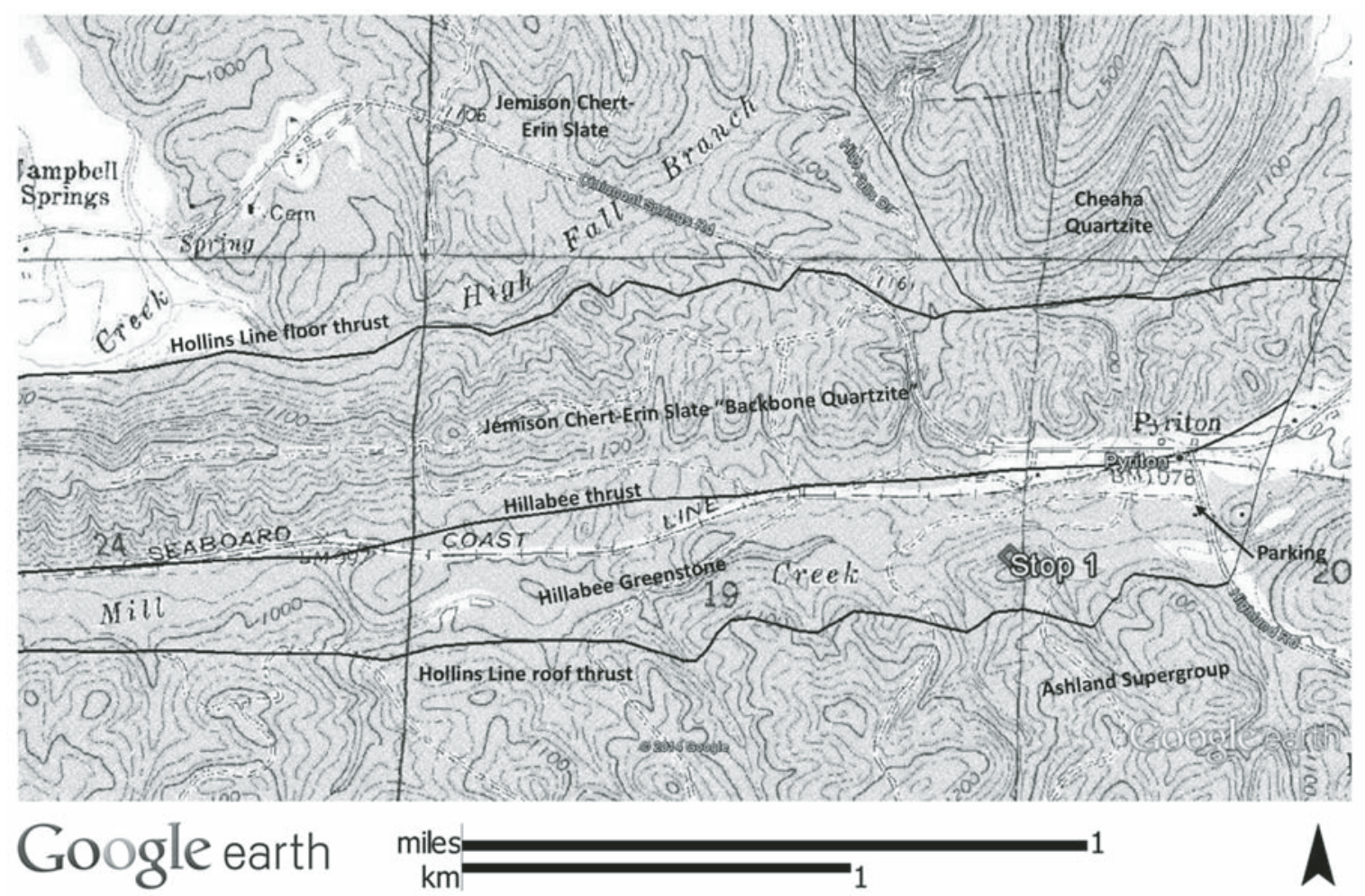

Figure 16. Location map and generalized geology for Stop 1.

makes pinpointing the exact location of the fault difficult, in the dirt track on the hillside, weathered greenstone is adjacent to saprolitic staurolite-bearing garnet-biotite-muscovite schist, allowing location of the Hollins Line roof thrust within a few meters. Preferential weathering of greenstone over quartzofeldspathic schist commonly creates an erosional scarp (Fig. 16) along the roof thrust.

North of Pyriton, the Cheaha Quartzite ridge trending south (Fig. 16) from Cheaha Mountain State Park bifurcates along a south-plunging syncline. The eastern limb of this syncline is truncated by the floor thrust of the Hollins Line fault immediately north of Pyriton (Fig. 16, High Falls Branch fault on Fig. 17), with rocks of the Jemison Chert-Erin Slate and structurally overlying Hillabee Greenstone contained in a thrust panel between the Hollins Line floor and roof thrust south of the Cheaha Quartzite ridge. North of the mine, the Hillabee Greenstone and structurally lower Jemison Chert-Erin Slate, a Middle Devonian-earliest Mississippian(?) sequence of metamorphosed chert, sandstone and pelitic rocks (Tull, 2002), are separated across the Hillabee fault - a poorly exposed pre-metamorphic thrust fault (Tull et al., 2007; Barineau, 2009) that emplaced rocks of the Hillabee Greenstone in a thrust panel atop rocks of the Paleozoic Laurentian shelf (Talladega Group). A distinctive metasandstone unit in the upper Jemison commonly holds up a pronounced ridge near its upper contact with the overlying Hillabee Greenstone (Posey Sandstone of Sutley, 1977). In the area depicted in Figure 16, this unit holds up a distinctive ridge in the region between the floor and roof thrust of the Hollins Line duplex. Although rocks of the Talladega belt are commonly truncated along the roof and floor thrust of the Hollins Line fault (i.e., stratigraphic cutoffs), internal stratigraphy of the Hillabee Greenstone (e.g., massive sulfide deposits, metadacites) and Jemison Chert-Erin Slate (e.g., Posey Sandstone) are not truncated. This relationship is easily observed here (Fig. 15), as east-west-trending massive sulfide zones in the Hillabee Greenstone parallel the east-west trending quartzite ridge of the Jemison Chert-Erin Slate. Similar relationships are observed along the length of the Talladega belt, providing an important constraint on emplacement of the Hillabee Greenstone atop rocks of the Talladega Group (Tull et al., 2007; Tull and Barineau, 2012). Because the Hillabee thrust apparently lacks both hanging wall and footwall stratigraphic cutoffs, it must have been emplaced along a significant hanging wall-footwall flat. This flat-on-flat geometry indicates that the Hillabee Greenstone did not travel over any significant thrust ramps during its emplacement. Additionally, because the thrust panel containing the Hillabee Greenstone lacks basement rocks, it must have been emplaced via thin-skinned thrusting along the Hillabee thrust. These characteristics indicate that the Hillabee Greenstone could not have been palinspastically separated from Late Paleozoic Laurentian shelf rocks of the Talladega Group by a significant distance. Because thrust faults typically climb through stratigraphic sequences along flats and ramps, the observation that the Hillabee was not significantly deformed during tectonic emplacement strongly suggests that it lay proximal to the Laurentian margin 


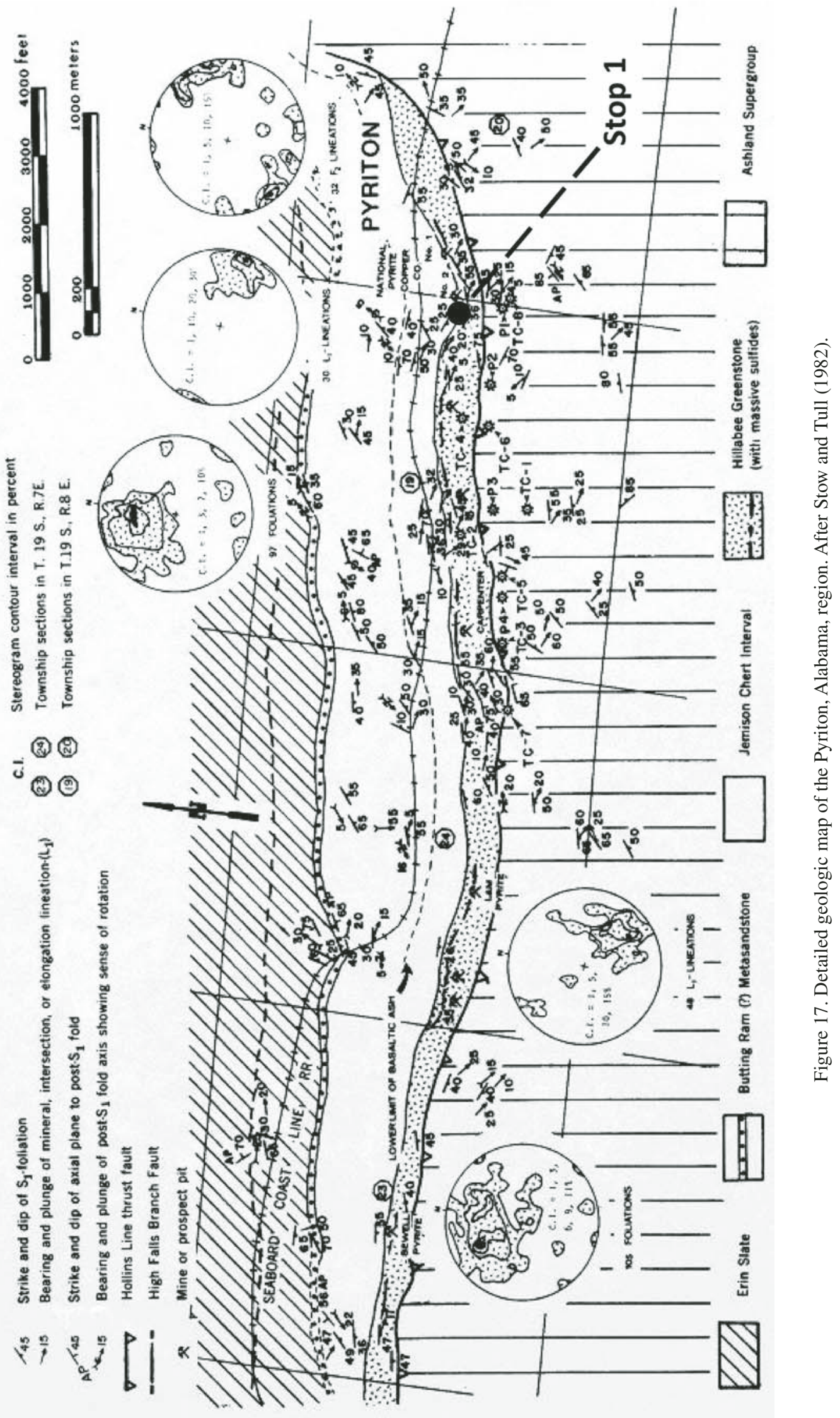




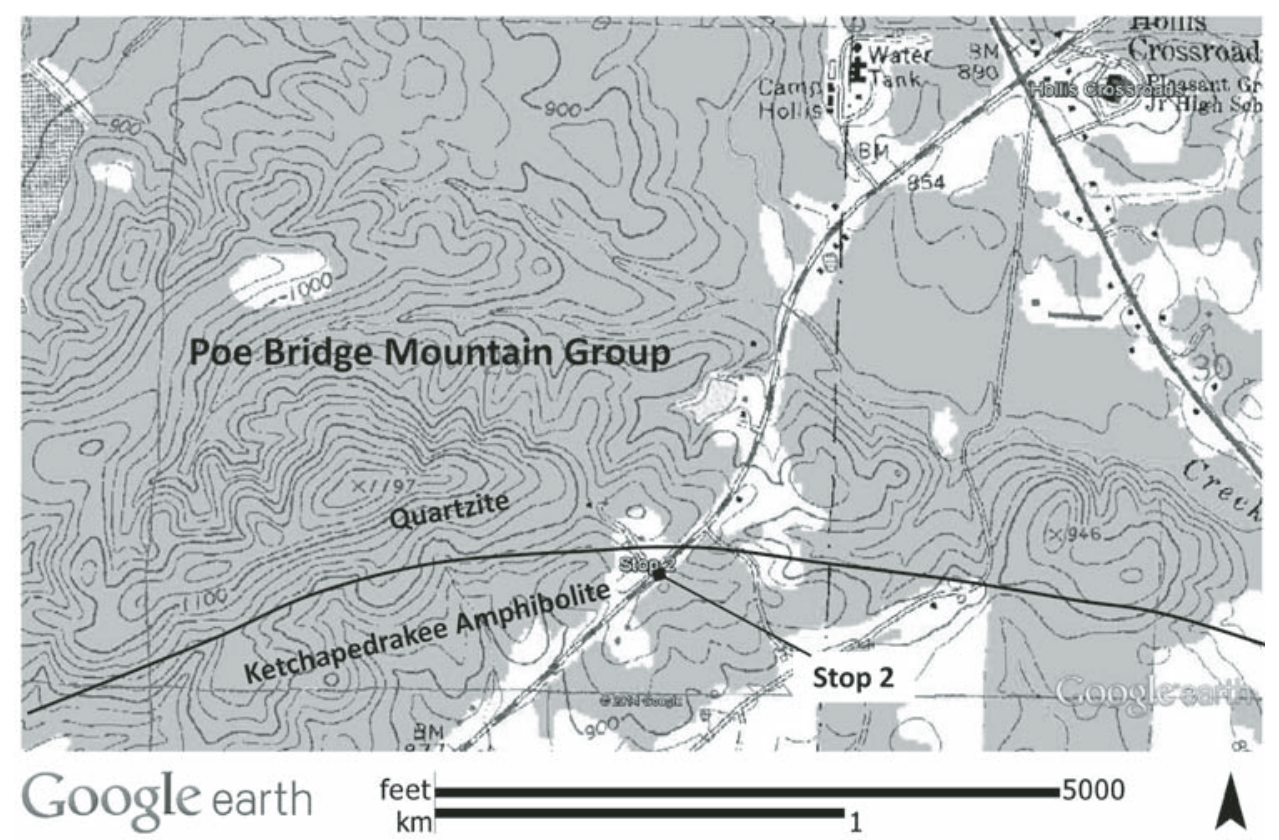

Figure 18. Location map and generalized geology for Stop 2. rocks of the Talladega Group, thus eliminating the need for it to climb one or more significant thrust ramps during emplacement.

- From the parking area, turn right (south) on Highlands Road toward Lineville, Alabama.

- After 5.7 miles on Highland Road/Watershed Road, turn left (east) on Talladega Street.

- After 0.8 miles, turn right (south) on 2nd Avenue North in downtown Lineville, Alabama.

- From the intersection of AL S.R.-49 and AL S.R.-9 in downtown Lineville, Alabama, drive north on S.R.-9 toward Hollis Crossroads, Alabama.

- Stop 2 is $~ 16.9$ miles from Lineville on S.R.-9 North. Rocks of the Poe Bridge Mountain Group are exposed on both sides of the highway in outcrops located $\sim 1.0$ miles south of the community of Hollis Crossroads, Alabama.

\section{STOP 2 ( 30 min): Poe Bridge Mountain Group, Ketchapedrakee Amphibolite (Ashland Supergroup) $\left(33.512974^{\circ} \mathrm{N}, 85.647114^{\circ} \mathrm{W}\right)$}

At Stop 2 (Fig. 18), a thick sequence of amphibolite is interlayered with subordinate fine-grained micaceous feldspathic quartzite (Fig. 19) in the lower Ashland Supergroup, along both sides of AL S.R.-9. Bedding-foliation strikes $\sim \mathrm{N} 80 \mathrm{E}$ and dips between $35^{\circ}$ and $70^{\circ}$ to the SE with evidence for both isoclinal folding of $\mathrm{S}_{0} / \mathrm{S}_{1}$ and younger open folds plunging $\sim 30^{\circ} \mathrm{S} 66 \mathrm{E}$. The $>400$ feet of outcrop belongs to the Poe Bridge Mountain Group, but at a higher stratigraphic level than the garnet-biotite-muscovite schists exposed in the hanging wall of the Hollins Line roof thrust at Pyriton, Alabama (Stop 1). Although the Poe Bridge Mountain Group and correlative Higgins Ferry Group (southwest of the Millerville antiform) are dominated by schist, the exposure here is predominantly orthoamphibolite (Ketchapedrakee Amphibolite) and micaceous-feldspathic metapsammite (Fig. 19). At other locations in the Ashland Supergroup, rocks of the Poe Bridge Mountain Group consist of rhythmically bedded metapelites and metagraywackes, suggestive of turbiditic sequences. $\mathrm{T}_{\mathrm{CHUR}}$ ages from metasedimentary rocks within the Ashland Supergroup range from 1119 to $964 \mathrm{Ma}$, suggesting a Grenville crustal source for their sedimentary protoliths (Das, 2006).

Thick and laterally extensive orthoamphibolites, including the Mitchell Dam and Ketchapedrakee Amphibolites, make up $\sim 7 \%$ of the lower Ashland Supergroup. Both Mitchell Dam and Ketchapedrakee amphibolites have geochemical characteristics typical of metamorphosed mafic rocks and are likely basalts

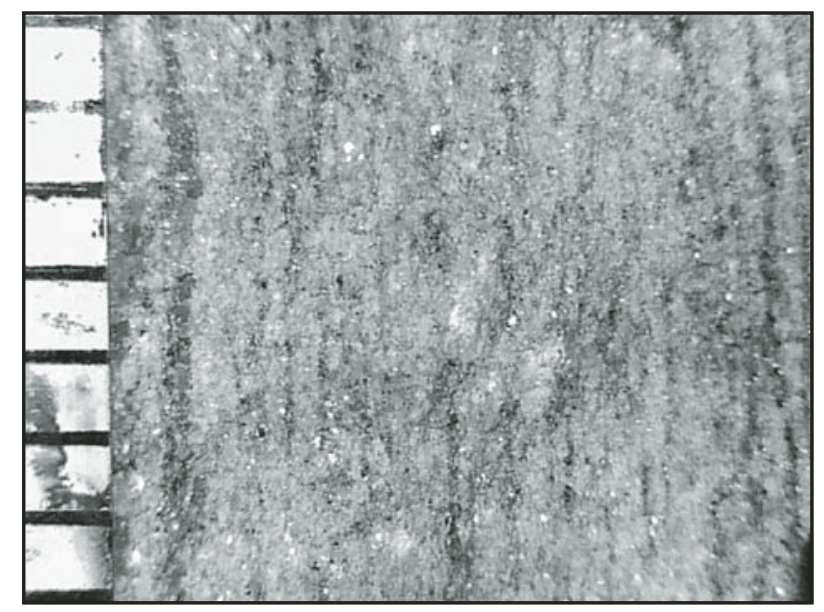

Figure 19. Fine-grained micaceous feldspathic quartzite, north end of Stop 2 exposure. 1/16 inch-ruled scale. 
and/or sills (Stow et al., 1984; Tull et al., 2012, 2014). Although amphibolites from the Ashland Supergroup have some chemical similarities with those of the structurally higher and stratigraphically younger Emuckfaw and Wedowee Groups, higher average concentrations of Ti in Poe Bridge Mountain amphibolites relative to those of younger WEDB amphibolites suggest a "withinplate" signature (Tull et al., 2012). Additionally, on the $\mathrm{Zr}$ versus $\mathrm{Zr} / \mathrm{Y}$ diagram of Pearce and Norry (1979), Poe Bridge Mountain amphibolites have a much more within-plate affinity than those of the overlying Emuckfaw Group (Tull et al., 2012), consistent with interpretations of a rift setting for both the Mitchell Dam and Ketchapedrakee amphibolites (Stow et al., 1984).

Age constraints on rocks of the Ashland Supergroup are less restrictive than rocks in the overlying Wedowee and Emuckfaw Groups. Detrital zircons from the upper Wedowee Group and geochemical indicators suggesting Grenville inheritance limit the Ashland Supergroup's depositional age between Mesoproterozoic and Middle Ordovician. However, the presence of thick metapelitic sequences, metagraywackes suggestive of turbiditic sequences, and orthoamphibolites with "within-plate" geochemical characteristics strongly suggests formation in a rift basin. Previous workers suggested that this rift basin formed along the Neoproterozoic-Early Cambrian margin of Laurentia following the breakup of Rodinia, interpreting rocks of the Ashland Supergroup as the Laurentian slope-rise (Tull et al., 2007, 2012). The allochthonous position on top of rocks of the Paleozoic shelf (Talladega belt) supports this interpretation and suggests telescoping of the continental margin juxtaposed rocks of the shelf and sloperise on either side of a thin panel of Hillabee Greenstone during Alleghanian deformation. However, in the absence of more precise age constraints, it is possible that the Ashland Supergroup represents the earliest phases of rifting in the Ashland-WedoweeEmuckfaw belt. If the latter model turns out to be correct, then no vestige of the Laurentian slope-rise is exposed/preserved in the southernmost Appalachians southwest of the Tennessee embayment. It is possible that back-arc rifting within the WEDB separated Laurentian slope-rise rocks from the shelf such that they lie east of the Brevard fault zone within the Inner Piedmont, similar to observations in the accretionary Lachlan orogen of southeastern Australia (Foster and Gray, 2000).

- Continue north on AL S.R.-9 toward Hollis Crossroads.

- After 1.0 mile, turn right (south) on

AL S.R.-1/U.S.-431 South.

- Continue south for 18.1 miles to Wedowee, Alabama.

- Stop for Lunch.

- From the intersection of County Road 48 (Broad St.) and AL S.R.-1/U.S.-431 South in downtown Wedowee, continue south on S.R.-1/U.S.-431 South.

- After 4.4 miles, turn right (west) on County Road 33.

- After 12.0 miles, turn right into an unmarked dirt-gravel driveway. Follow the driveway 0.4 miles toward the Tallapoosa River. Park near a connecting road on the right and walk down the hill toward the river ( $>000$ feet). Stop 3 is a large outcrop immediately below the house on the eastern bank of the Tallapoosa River. Please obtain permission from property owner John Hall to view the Stop 3 outcrop, if you are not traveling with the 2015 GSA field trip group.

\section{STOP 3 ( 45 min): Wedowee-Emuckfaw Group Contact $\left(33.138572^{\circ} \mathrm{N}, 85.560178^{\circ} \mathrm{W}\right)$}

This outcrop lies within the contact zone between the Wedowee Group and overlying Emuckfaw Group. We thank the owner of this property, Mr. John Hall, for allowing us access to this outcrop (Fig. 20). As at most other localities in the AshlandWedowee-Emuckfaw belt, this contact is transitional, with graphitic schist in the uppermost Wedowee grading into garnetiferous metagraywackes and garnet mica schist of the younger Emuckfaw Group. Because of lithologic contrasts observed here, and the presence of amphibolite bodies south of this locality (Beaver Dam Amphibolite, Stop 4), we map the Wedowee-Emuckfaw contact at this location, not as shown on the Alabama State Geologic Map of Osborne et al. (1988) (Tull and Campbell, 2012). This contact has been the subject of much debate, with some workers interpreting the two units in faulted contact throughout the entire eastern Blue Ridge of Alabama (e.g., Bieler and Deininger, 1987; Osborne et al., 1988; Steltenpohl et al., 2013).

Here, a $>50 \mathrm{ft}$ cliff exposure of interlayered paragneiss and variably graphitic garnet mica schist lies in the transition zone between the Wedowee and Emuckfaw Groups. Southwest of this location, on the western side of the Tallapoosa River, $>400 \mathrm{~m}$ of metagraywacke and garnet muscovite schist is exposed in the river bottom at low-flow conditions (Stop 10 of Tull and Barineau, 2012). These rocks belong to the Josie Leg Formation of the lower Emuckfaw Group, as do amphibolites of the Beaverdam Amphibolite exposed at Stop 4. In the field adjacent to this outcrop, along the slope at its eastern edge, abundant graphitic schist float has weathered out of rocks of the uppermost Wedowee Group. There is no structural break between rocks of the Wedowee and Emuckfaw Groups at this locale. $\mathrm{S}_{0} / \mathrm{S}_{1}$ orientations here and immediately downstream are ENE $\left(070-085^{\circ}\right)$, dipping shallowly $\left(20^{\circ}-30^{\circ}\right)$ to the southeast. No evidence for significant cataclasis or brittle deformation has been recognized in this area, consistent with interpretations by Drummond et al. (1997) and Tull and Campbell (2012) that displacement along the Alexander City fault terminates SSW of Alexander City, Alabamamore than $75 \mathrm{~km}$ (45 miles) to the southwest. Although rocks here exhibit evidence for shearing under ductile conditions (e.g., crenulation, sigmoidal porphyroclasts, pressure shadows), the kinematics of these shear fabrics (Fig. 21) are ubiquitous to units of the Ashland-Wedowee-Emuckfaw belt and are commonly found in micaceous units-especially in areas where there is a mechanical contrast (e.g., schist and paragneiss) between different lithologies. Similar shear fabrics can be observed in orthogneiss bodies far from observed or mapped fault zones (Fig. 21).

- Return to vehicle and County Road 33. Turn left (north) on County Road 33.

- After 1.7 miles, turn right (south) on County Road 43. 


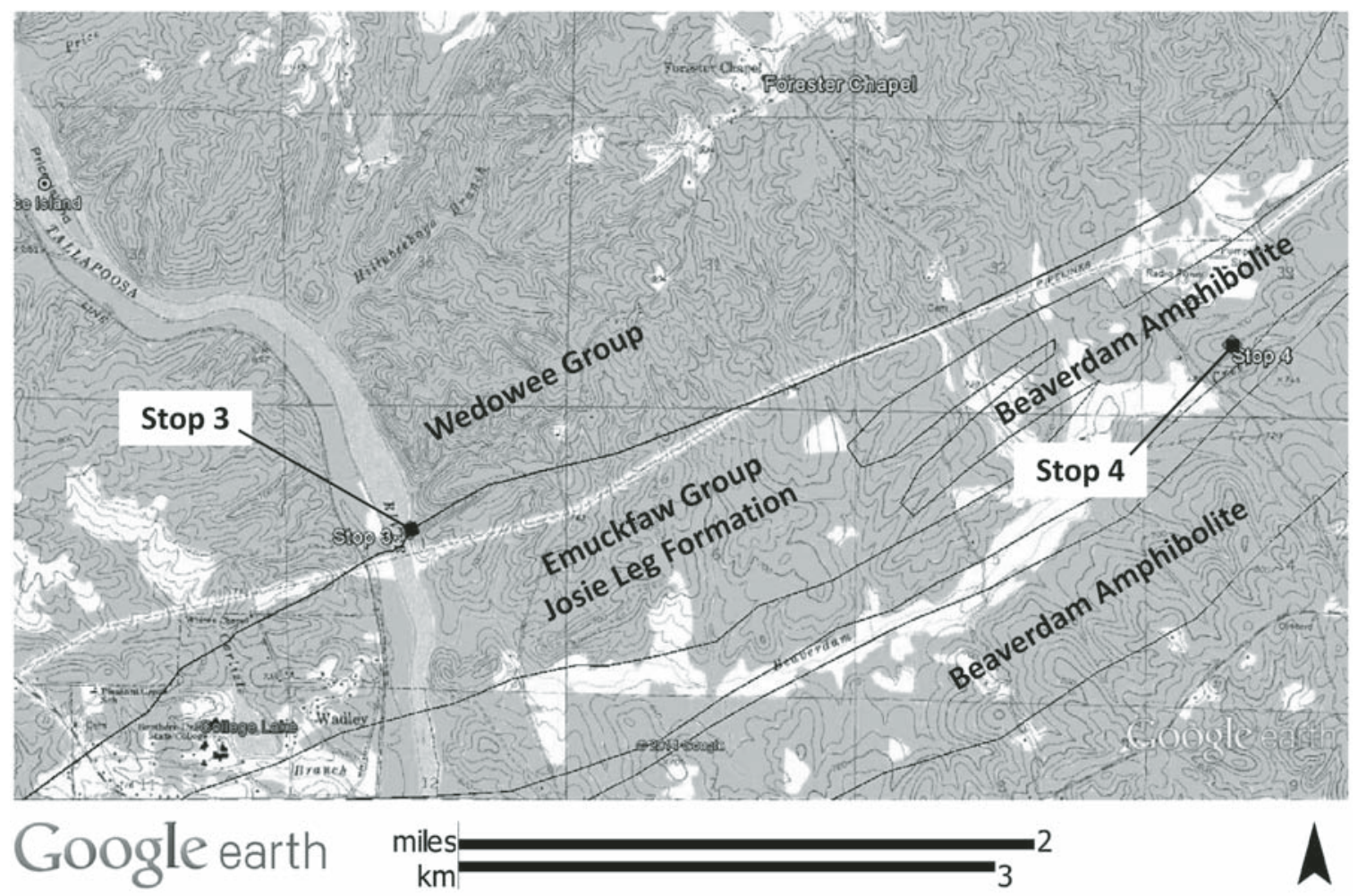

Figure 20. Location map and generalized geology for Stops 3 and 4.

- After 2.4 miles, turn left (north) on County Road 41.

- After 0.3 miles, turn right on County Road 825.

- Stop 4 is on the north side of County Road 825, 750 feet northeast of its intersection with County Road 41.

\section{STOP 4 ( 30 min): Beaverdam Amphibolite of} the Josie Leg Formation, Lower Emuckfaw Group $\left(33.147938^{\circ} \mathrm{N}, 85.510719^{\circ} \mathrm{W}\right)$

Amphibolite boulders on both sides of County Road 825 (Beaverdam Amphibolite of Bentley and Neathery, 1970) are derived from local outcrops (Fig. 20). Although the majority of these boulders are detached from the underlying bedrock here, at other locations in the area, abundant saprolitic amphibolite interlayered with schist and paragneiss suggests the Beaverdam Amphibolite originated as flows and/or sills in the WEDB. Like the majority of metamafic rocks in the WEDB, Beaverdam Amphibolite is moderately enriched in large ion lithophile elements, and have negative $\mathrm{Nb}$ anomalies and flat REE patterns typical of suprasubduction mafic rocks. Southwest of this locality, rocks of the Emuckfaw Group are intruded by the ca. 450430 Ma Zana and Kowaliga metagranitoids. Coupled with the age of detrital zircons from the lowermost Emuckfaw Group, and assuming that these amphibolites formed coevally with deposition of metasedimentary rocks, this constrains the probable crystallization age to late Middle-Late Ordovician.
- Turn around on County Road 825 . Return $~ 750$ feet southwest to the intersection of County Road 825 and County Road 41.

- Turn left (south) on County Road 41.

- After 1.0 miles, turn left (east) on AL S.R.-22.

- After 8.0 miles, turn right on Main Street/S.R.-22.

- After 1.6 miles, turn left (north) on AL S.R.-1/U.S.-431.

- From the intersection of AL Hwy 22 and S.R.-1/U.S.-431, travel north.

- After 1.3 miles, turn right (north) on County Road 79.

- Turn left into the dirt driveway 200 feet from the intersection of County Road 79 and S.R.-1/U.S.-431. Optional Stop 5 is in the hillside on a graded construction site immediately west of County Road 79.

\section{Optional STOP 5 ( 30 min): Jacksons Gap Group, Brevard Fault Zone $\left(33.168840^{\circ} \mathrm{N}, 85.372360^{\circ} \mathrm{W}\right)$}

This locale (Fig. 22) is in the uppermost part of the Jacksons Gap Group in the Brevard fault zone, immediately northwest of the Dadeville Complex. Chlorite actinolite schist and quartzite exposed in the hillside is part of a sequence of quartzite, phyllonite, mylonitic gneiss, and rare carbonate and metaconglomerate commonly referred to as the Jacksons Gap Group (Bentley and Neathery, 1970; Wielchowsky, 1983; Steltenpohl et al., 1990; Sterling, 2006). Similar quartzite sequences in the Jacksons Gap 

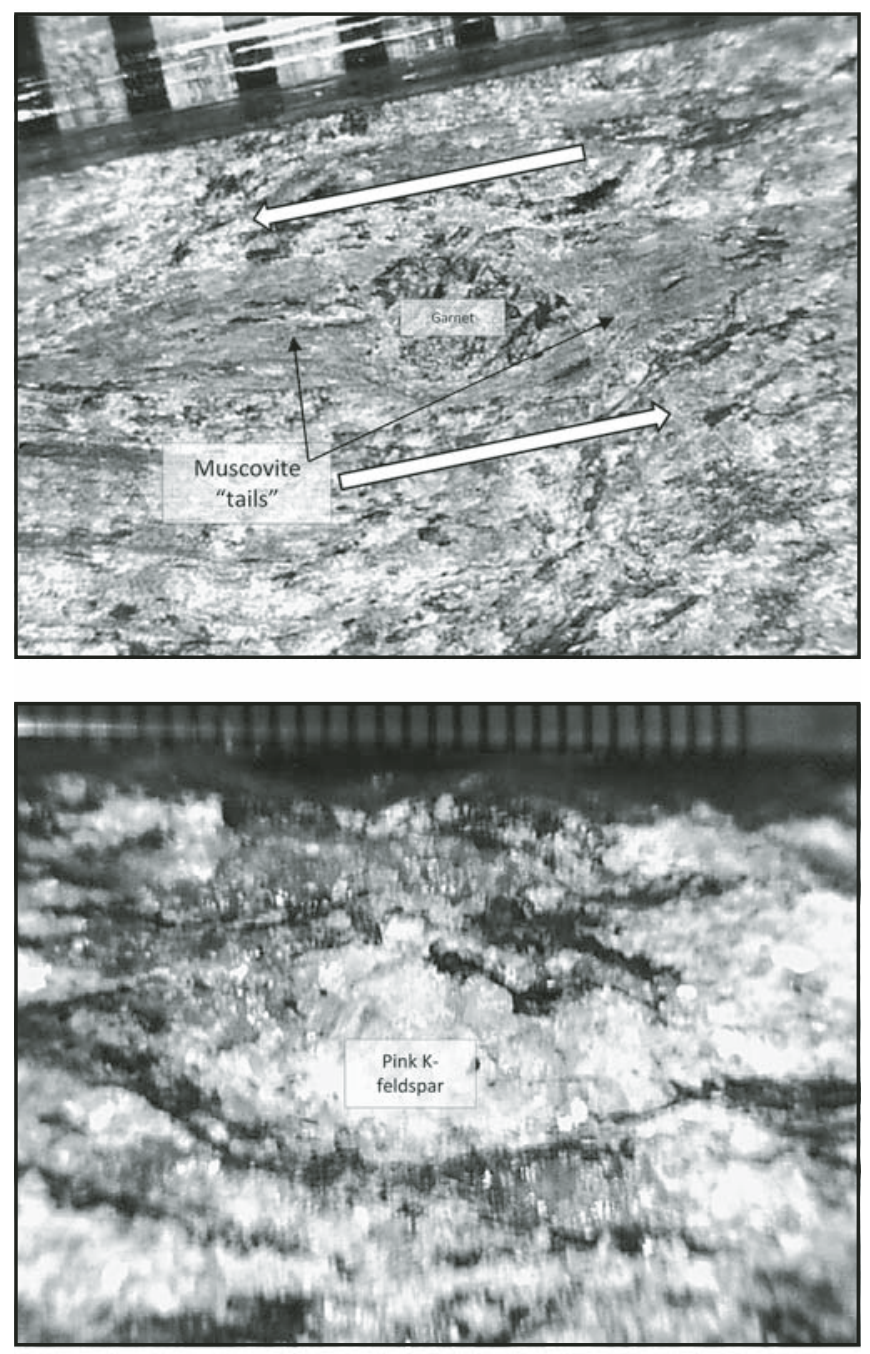

Figure 21. (Top) Garnet-biotite-muscovite quartzofeldspathic paragneiss (metagraywacke). Oriented sample along-strike view $(\sim \mathrm{S} 84 \mathrm{~W})$. Foliation dips to the left (SE). Sigma-style porphyroclast indicates down-dip shearing. Crenulation axes and mineral lineations oriented $\sim$ S39W. Millimeter-ruled scale. (Bottom) Sigmoidal, pink k-feldspar crystal from the Kowaliga Gneiss, $\sim 11 \mathrm{~km}$ southeast of Stop 3. Millimeter-ruled scale.

Group (Martin Dam and correlative Devil's Backbone Quartzite) and Loachapoka Formation in the Opelika Complex (Saugahatchee Quartzite) have led a number of authors (e.g., Grimes et al., 1993) to suggest that the two sequences are equivalent.

Southeast of this stop, rocks of the Dadeville Complex are separated from the Jacksons Gap Group across the Katy Creek fault. Rocks immediately southeast of the Katy Creek fault include the Ropes Creek Amphibolite and Waresville Formation. Protoliths for these metamafic rocks are generally considered to be basalts and mafic to intermediate tuffs. At other locales, these metaigneous rocks are intercalated with andesitic and/or dacitic gneisses, subordinate metapelites, metagraywacke, metachert, and calc-silicate gneiss, as well as mafic and ultramafic olisto- stromes interpreted as ophiolitic mélange (Neathery, 1968; Clark, 1973; Brown and Cook, 1981; Sears et al., 1981). As much as 50\% of the Dadeville Complex consists of metamorphosed ultramafic to felsic plutons (e.g., Franklin Gneiss, Doss Mountain Suite). The geochemical character of the predominant mafic and subordinate intermediate igneous rocks suggests genesis in a suprasubduction setting (Stow et al., 1984; Spell and Norrell, 1990). However, unlike rocks of the WEDB, metasedimentary rocks of the $>6-\mathrm{km}$-thick Dadeville Complex comprise only a small percentage of the total sequence. Based on its lithologic and geochemical character, the Dadeville Complex could be the Taconic arc in the southernmost Appalachians. To date, the only age constraints come from a whole rock $\mathrm{Rb}-\mathrm{Sr}$ age on the batholith-scale metagranitoid Franklin Gneiss. The $462 \pm 4 \mathrm{Ma}$ age (Seal and Kish, 1990) could indicate a Middle Ordovician crystallization age, but modern single-grain ion microprobe geochronologic analysis is warranted.

- From dirt driveway at optional Stop 5, turn right on County Road 79 to its intersection with AL S.R.-1/U.S.-431. Turn right (north) on S.R.-1/U.S.-431.

- After 12.2 miles, turn left (west) on AL S.R.-48/West Broad Street in downtown Wedowee, Alabama.

- After 15.5 miles, turn left (south) on AL S.R.-9/East Main Street in Lineville, Alabama.

- After 0.8 miles, turn left (south) to stay on AL S.R.-9/East Main Street.

- After 0.5 miles turn right (south) to stay on AL S.R.-9.

- After 5.2 miles, turn left (south) to stay on AL S.R.-9 in Ashland, Alabama.

- After 19.8 miles, turn left on Railroad Place in Goodwater, Alabama.

- Park on the left (north) side of Railroad Place 100 feet southeast of the intersection of Railroad Place and AL S.R.-9, next to the railroad tracks. Stop 6 is beneath the S.R.-9 bridge over the rail line.

\section{STOP 6 ( $\sim 30$ min): Goodwater fault $\left(33.065998^{\circ} \mathrm{N}, 86.053387^{\circ} \mathrm{W}\right)$}

A steeply dipping, 1-m-wide shear zone in this saprolitic outcrop is the type locality of the Goodwater-Enitachopco fault (Fig. 23). The Goodwater-Enitachopco fault separates rocks of the Wedowee Group in the hanging wall from rocks of the Ashland Supergroup (Hatchett Creek and Higgins Ferry Groups) in the footwall (Fig. 24). Rocks of the Wedowee Group were intruded by a small body of Rockford-"type" granitic pegmatite (Fig. 24). Map-scale units in the footwall (Ashland Supergroup) are truncated at a high angle to this structure (Fig. 24), while drag folds in stratigraphy adjacent to the fault clearly indicate a significant normal component of slip (Fig. 25). Foliation in rocks across the fault zone is truncated in this shear zone, indicating postmetamorphic displacement. Additionally, because the Goodwater-Enitachopco fault cuts the Millerville antiformwhich also folds Pennsylvanian rocks in the foreland-we 


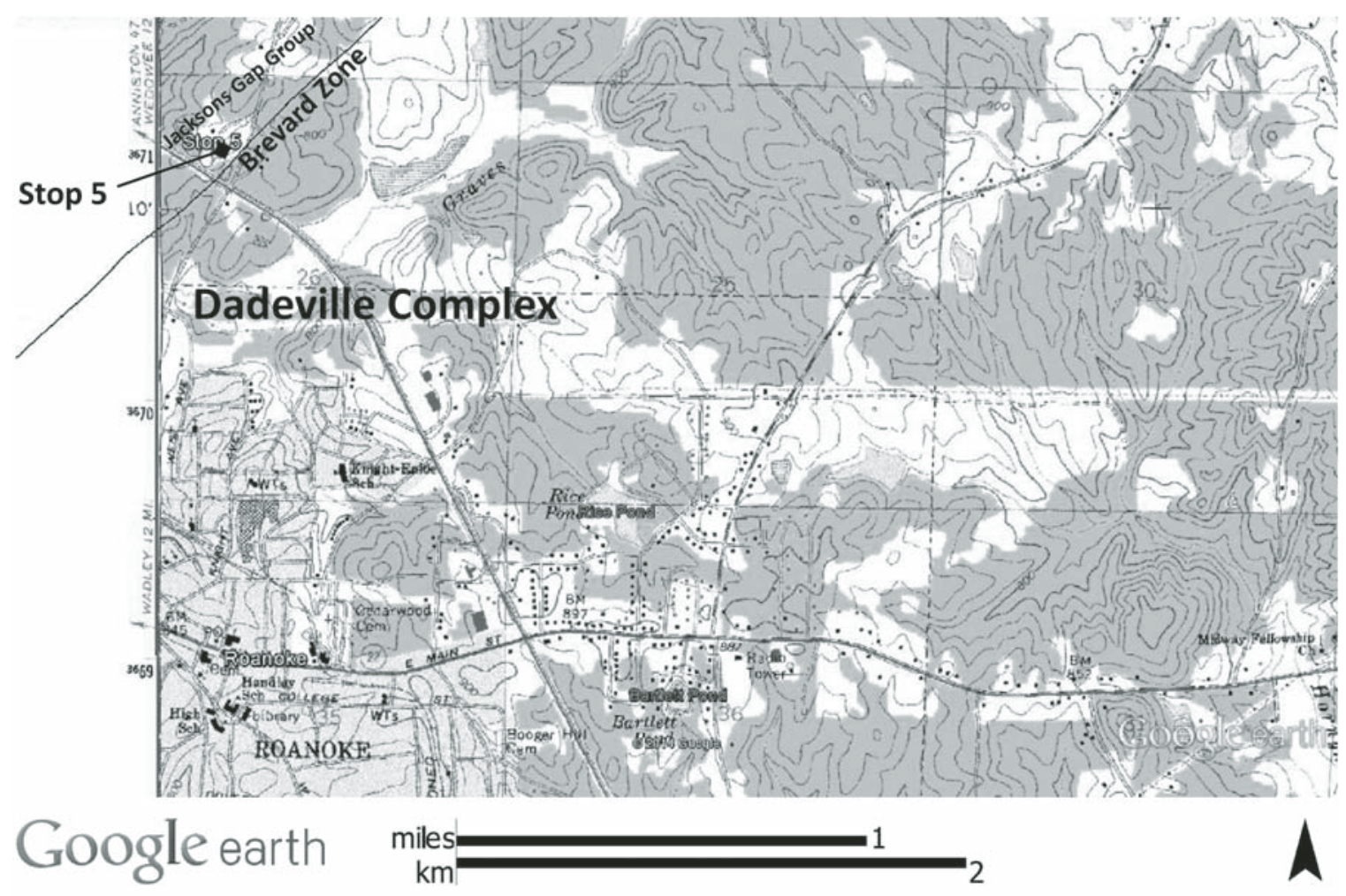

Figure 22. Location map and generalized geology for optional Stop 5.

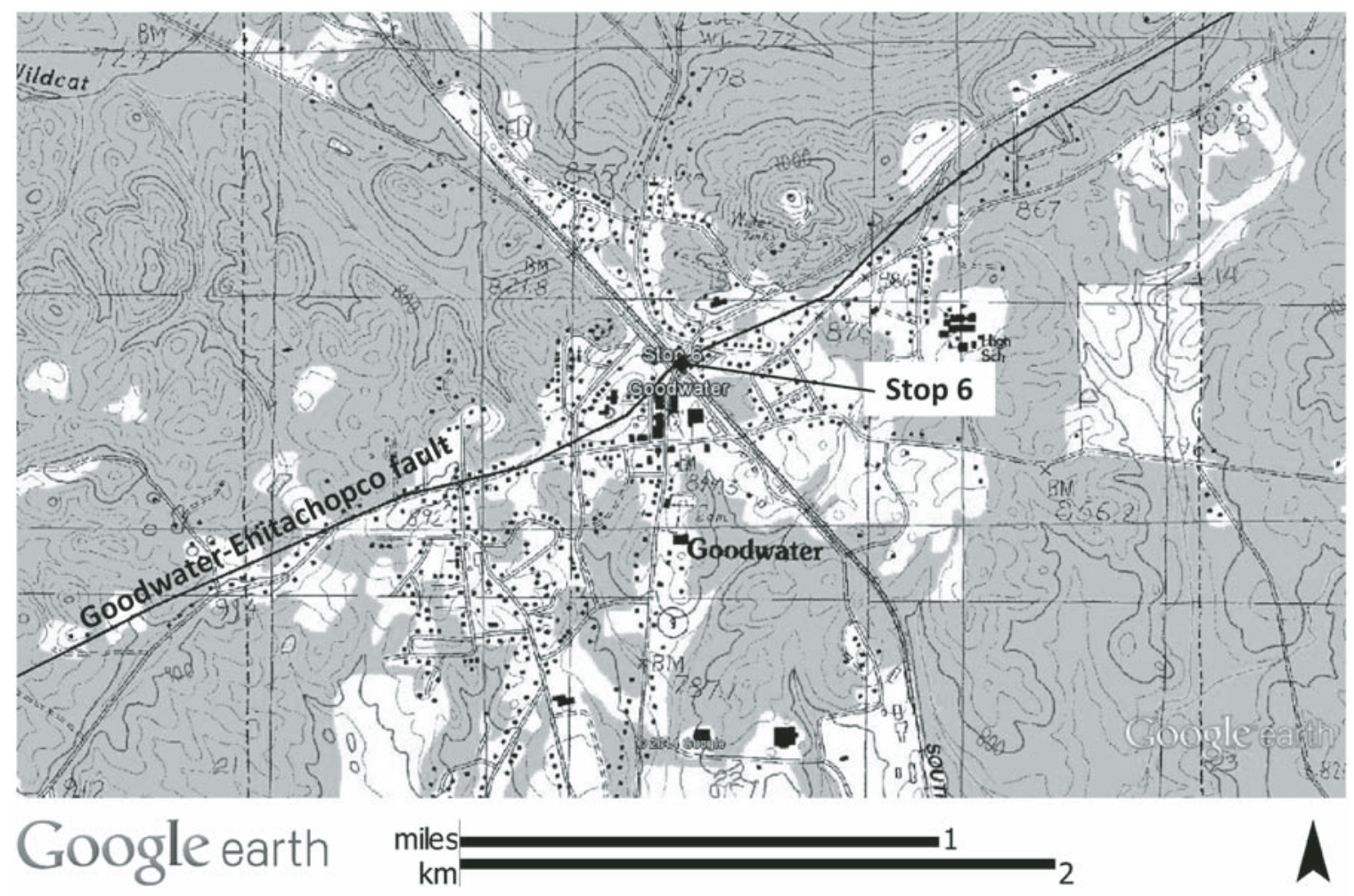

Figure 23. Location map for Stop 6. 


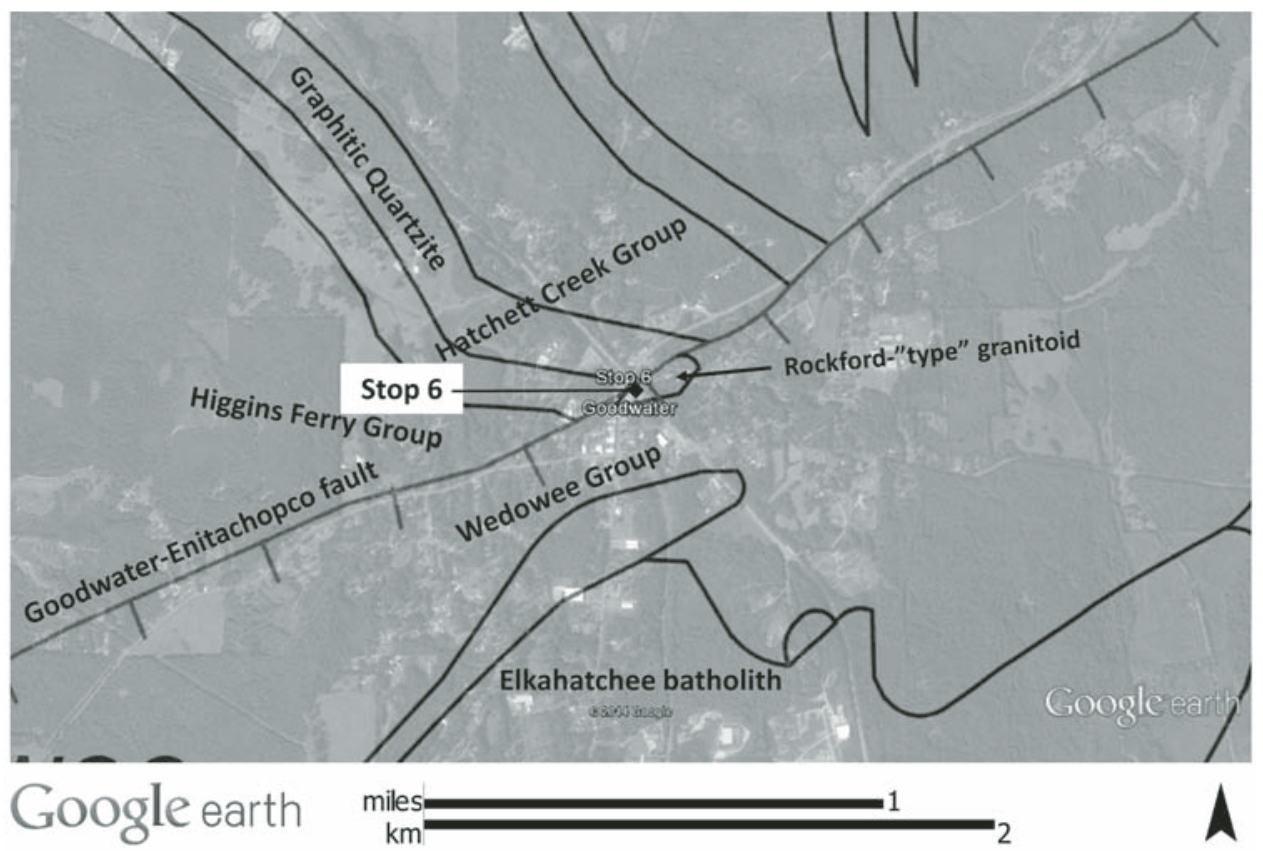

Figure 24. Geologic map for Stop 6.

suggest the Goodwater-Enitachopco can be no older than Pennsylvanian. This contrasts with the ca. $330 \mathrm{Ma}$ age assigned to motion along this fault postulated by Steltenpohl et al. (2013), who based their interpretation on an ${ }^{40} \mathrm{Ar} /{ }^{39} \mathrm{Ar}$ cooling age from a sheared pegmatite at this locale. However, age constraints placed on peak metamorphism by pre-, syn-, and post-kinematic plutons from the Ashland-Wedowee-Emuckfaw belt (Ingram, 2012) sug- gest this ca. $330 \mathrm{Ma}$ age is associated with dynamothermal metamorphism and predates brittle deformation in this fault zone.

Approximately $25 \mathrm{~km}$ to the southwest, displacement along this fault terminates, with rocks of the Ashland Supergroup and overlying Wedowee Group mapped as being in stratigraphic contact. In the area near Pentonville, Alabama, rocks of the Hatchett Creek Group are folded around the southwestern tip of the fault

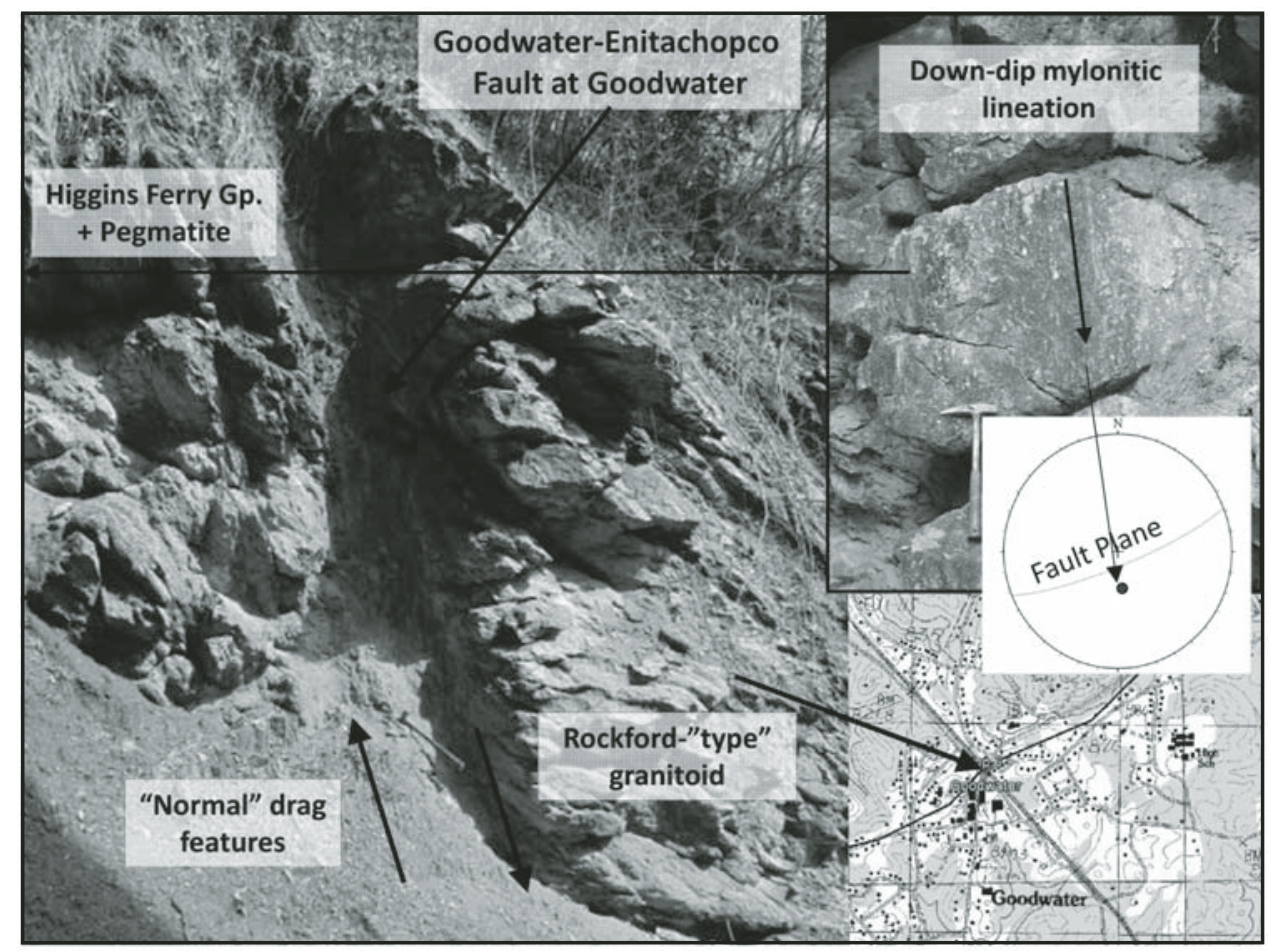

Figure 25. Goodwater fault exposed in downtown Goodwater, Alabama. 
as part of a displacement transfer fold (D. Allison, 2014, written commun.). Recognition that, at least over part of their contact length, the Ashland Supergroup and Wedowee Group lie in stratigraphic contact with one another provides critical constraints on the development of the WEDB, since the basal strata of this backarc sequence appears to have been built on rocks interpreted as the Neoproterozoic-Cambrian Laurentian slope-rise sequence.

Stop 6 concludes Day 2 of the field trip. From Goodwater, Alabama we will return to Cheaha Mountain State Park ( 1 h). Dinner is available at the park restaurant.

\section{Day 3. Sunday, 22 March 2015}

\section{Eastern Blue Ridge, Georgia-Wedowee, Emuckfaw, and New Georgia Groups, and Dahlonega Gold Belt}

All participants should have breakfasted and checked out of the hotel. We will depart from the parking lot below the hotel at 8:30 a.m. CDT.

- At the park entrance, turn left (north) on AL S.R.-281 (Talladega Scenic Byway).

- After 9.7 miles, exit left (west) off of AL S.R.-281 toward County Road 24.

- Turn left (east) on County Road 24.

- After 4.7 miles, turn right (south) on AL S.R.-1/U.S.-431.

- After 9.7 miles, turn left (east) on County Road 82.

- After 12.3 miles, turn left (east) on AL S.R.-48.
- After 4.8 miles, AL S.R.-48 crosses the Alabama-Georgia state line and becomes GA S.R.-5. Stay on GA S.R.-5. We will be on eastern daylight time from this point until our return to Chattanooga, Tennessee.

- After 0.9 miles, turn right (east) to stay on GA S.R.-5. Stop 7 is 3.1 miles from this point on S.R.-5, 500 feet west of the intersection of S.R.-5 and Old Columbus Road.

\section{STOP 7 ( 30 min): Schist and Metagraywacke of the Josie Leg Formation, Lower Emuckfaw Group $\left(33.475800^{\circ} \mathrm{N}, 85.240169^{\circ} \mathrm{W}\right)$}

Biotite muscovite paragneiss (metagraywacke) and quartzofeldspathic biotite muscovite schist is exposed in saprolite on both sides of the road (Fig. 26). Several large, fresh boulders of metagraywacke are located along the cut and at the west end along the power line. West of this exposure $(\sim 1400 \mathrm{ft})$ in a similar outcrop on the west side of Mountain Creek, a roadcut exposes a sequence of graphitic schist. The contact between these two units traces through the vicinity of Mountain Creek (Fig. 27). This contact was mapped from here south into Alabama and north to the Mulberry Rock recess (Fig. 2)-which we interpret as the contact between the Wedowee Group and Emuckfaw Group. Along its entire length, this contact separates graphitic schist (Wedowee Group) from metagraywacke and amphibolite (Josie Leg Formation, Emuckfaw Group). This same contact on the

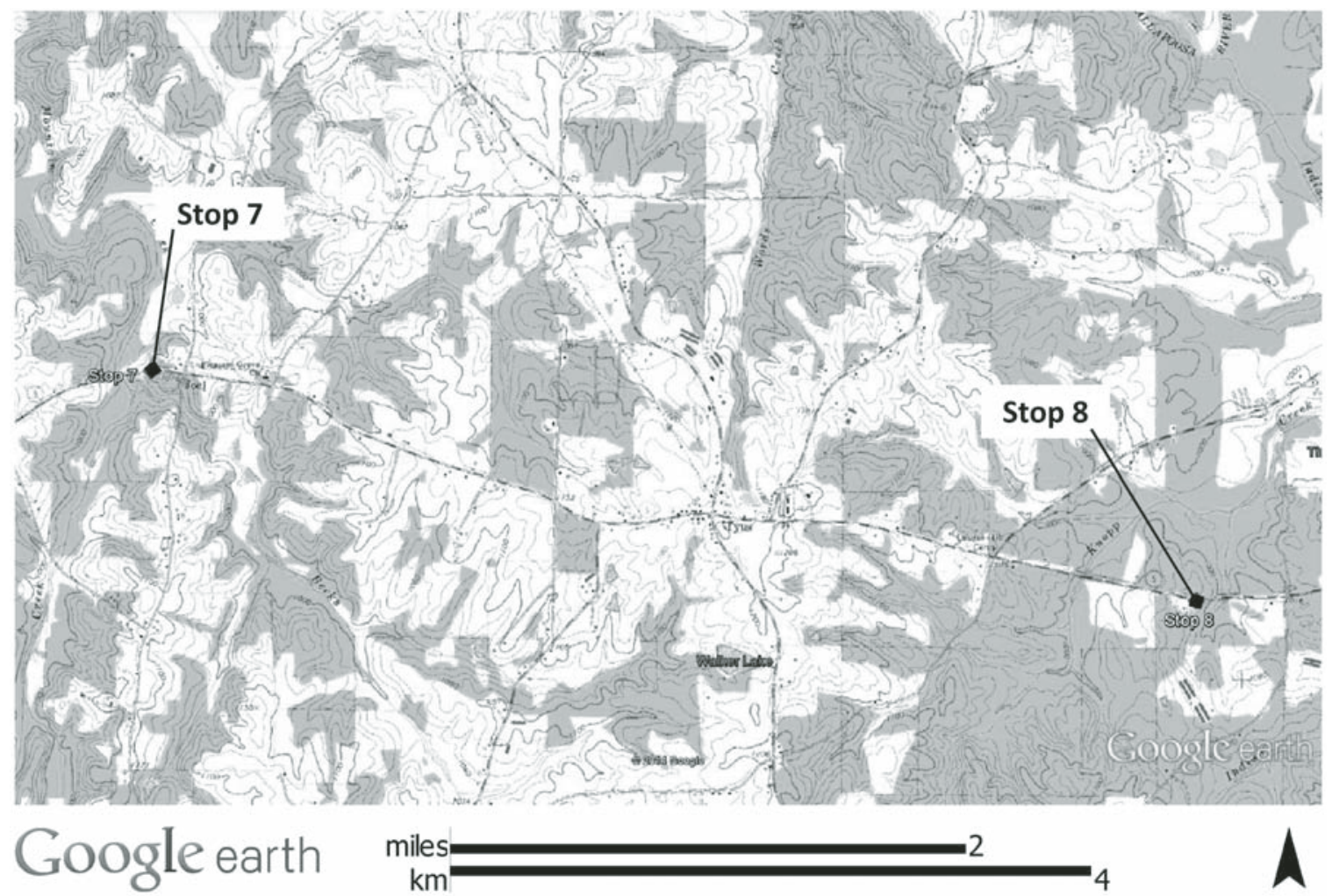

Figure 26. Location map for Stops 7 and 8 west of Roopville, Georgia. 


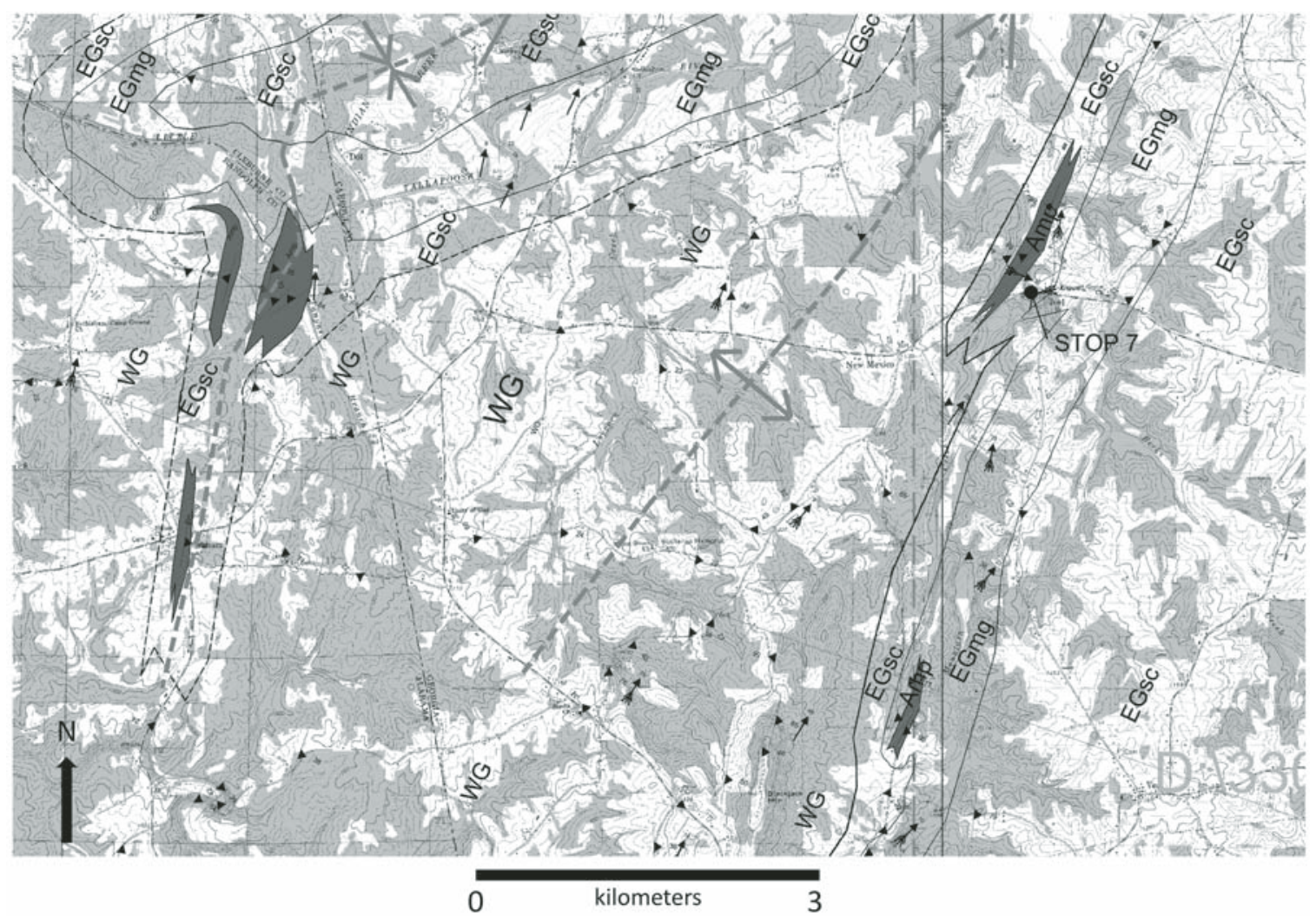

Figure 27. Geologic map of a portion of the Roopville and Graham quadrangles (Stop 7). Mapped by Valerie Smith with funding from the Educational Mapping Cooperative (EDMAP), USGS. WG-Wedowee Group; EG-Emuckfaw Group; Amp-amphibolite.

Tallapoosa River near Wadley, Alabama, was seen at Stop 3 and consisted of metagraywacke structurally and stratigraphically above graphitic schist. Structural elements in the Wedowee and Emuckfaw Groups are similar and suggest that they share a common deformation history (Figs. 28, 29, and 30). As the contact is traced north into Georgia, it is folded by large (half-wavelength $>5 \mathrm{~km}$ ) tight to isoclinal, north-plunging anticlines and synclines (Figs. 2 and 27) that cause this contact to step westward from the Alabama to Georgia section. The hinge zone shows bedding and foliation commonly overturned to the northwest. This location is part of a parasitic structure on this folded contact.

Our mapping contrasts with earlier workers (e.g., McConnell and Abrams, 1984; German, 1989). Rocks in this area were assigned to the Dog River-Andy Mountain-Bill Arp Formations of the "western Sandy Springs Group" on the eastern limb of a large antiformal thrust nappe that required that stratigraphy of the "western Sandy Springs Group" close around the hinge of this $>35-\mathrm{km}$-wide structure in eastern Alabama. Because we do not observe closure of stratigraphy around the projected "fold hinge" in eastern Alabama, we propose that stratigraphy on the northwestern and southeastern margins of this thrust sheet represents two distinct stratigraphic packages corresponding with the Wedowee and Emuckfaw Groups of Alabama.

- Continue east on GA S.R.-5 toward Roopville, Georgia.
- Stop 8 is 4.2 miles west of this location on the south side of GA S.R.-5, 1700 feet west of the intersection of S.R.-5 and Needmore Road.

\section{STOP 8 ( $30 \mathrm{~min})$ : Amphibolite of the Josie Leg Formation, Lower Emuckfaw Group $\left(33.462824^{\circ} \mathrm{N}, 85.169532^{\circ} \mathrm{W}\right)$}

Amphibolite is exposed over $>300$ feet in a roadcut on the south side of GA S.R.-5 at this location (Figs. 26 and 31). Like similar amphibolites (e.g., Beaverdam Amphibolite) in the Alabama Ashland-Wedowee-Emuckfaw belt, this amphibolite body is assigned to the lower portion of the Emuckfaw Group, Josie Leg Formation. A sample collected for geochemical analysis plots in the basalt field on the total alkalis versus silica diagram of Le Maitre and IUGS Working Group (1989), and exhibits the same geochemical characteristics of the majority of metamafic rocks found throughout the WEDB-moderate enrichment in large ion lithophile elements and a flat REE pattern typical of suprasubduction-zone mafic rocks.

- Continue east on GA S.R.-5 toward Roopville, Georgia.

- After 2.8 miles, turn left (north) on GA S.R.-1/U.S.-27 toward Carrollton, Georgia.

- Lunch. 

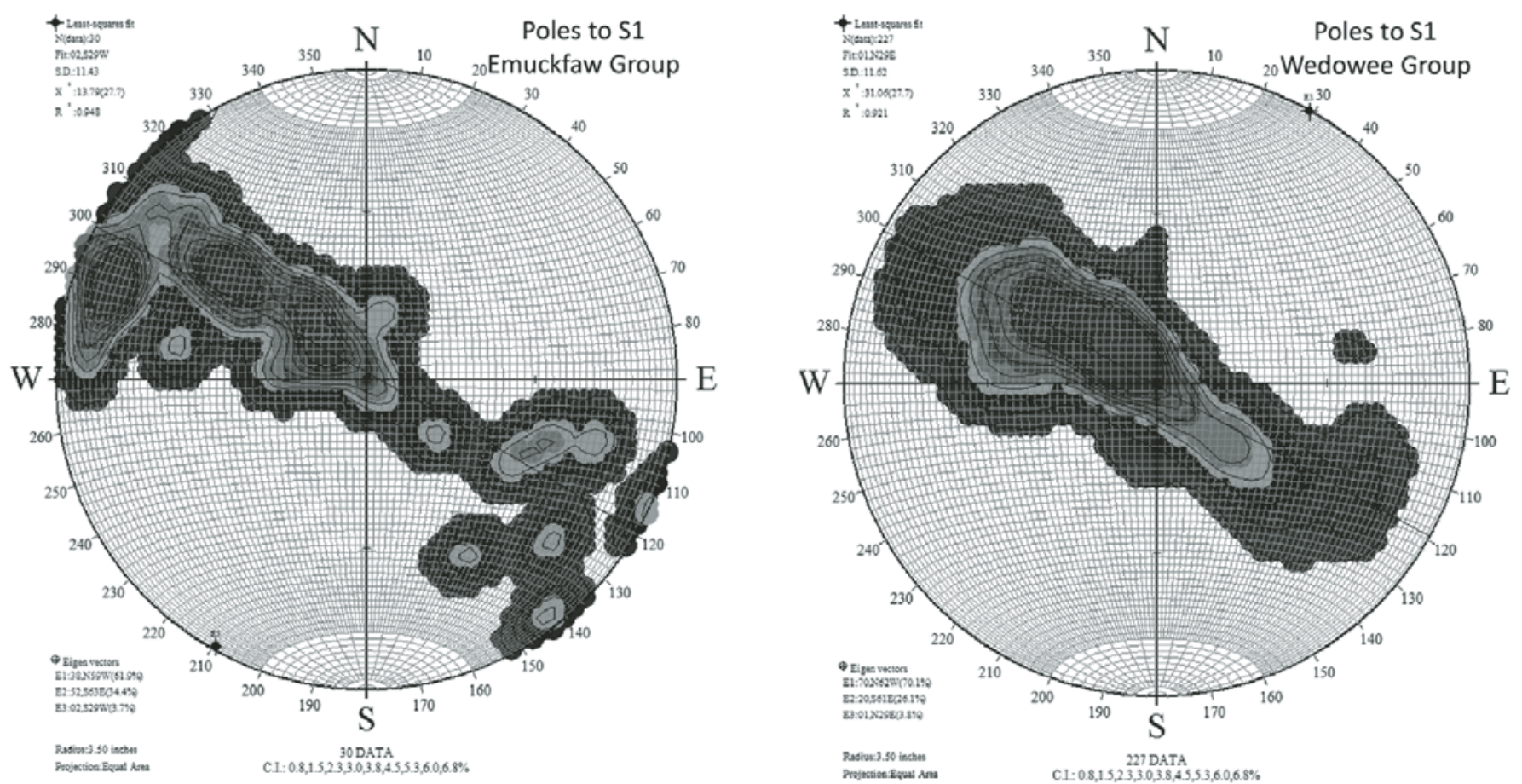

Figure 28. Contoured $\mathrm{S}$ poles to foliation (1\%) for the Emuckfaw (left) and Wedowee (right) Groups in the Graham and Roopville 7.5 min quadrangles from Smith and Tull (2014).
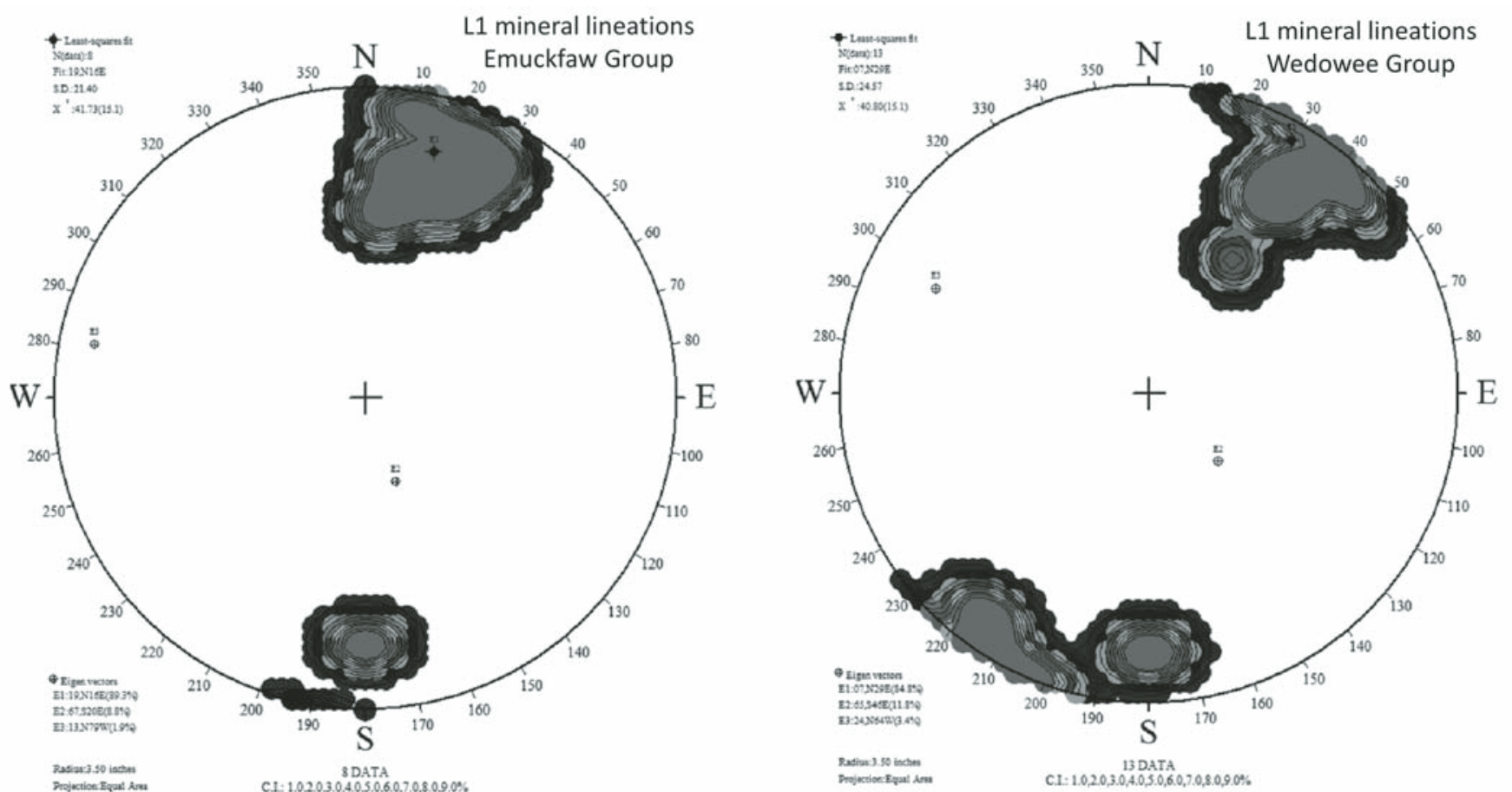

Figure 29. Contoured $\mathrm{L}_{1}$ lineations (1\%) for the Emuckfaw (left) and Wedowee (right) Groups in the Graham and Roopville 7.5 min quadrangles from Smith and Tull (2014). 

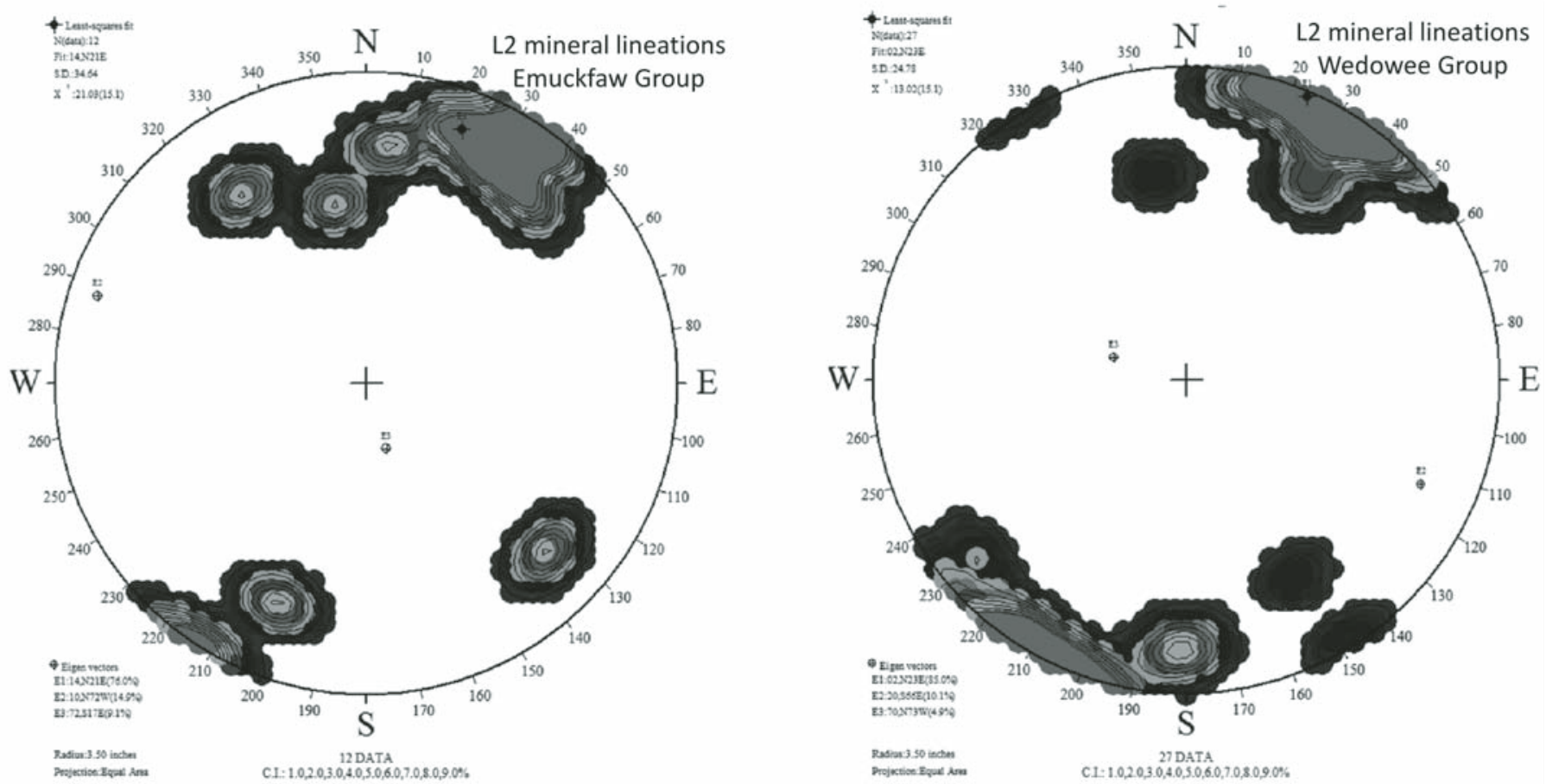

Figure 30. Contoured $\mathrm{L}_{2}$ lineations (1\%) for the Emuckfaw (left) and Wedowee (right) Groups in the Graham and Roopville 7.5 min quadrangles from Smith and Tull (2014).

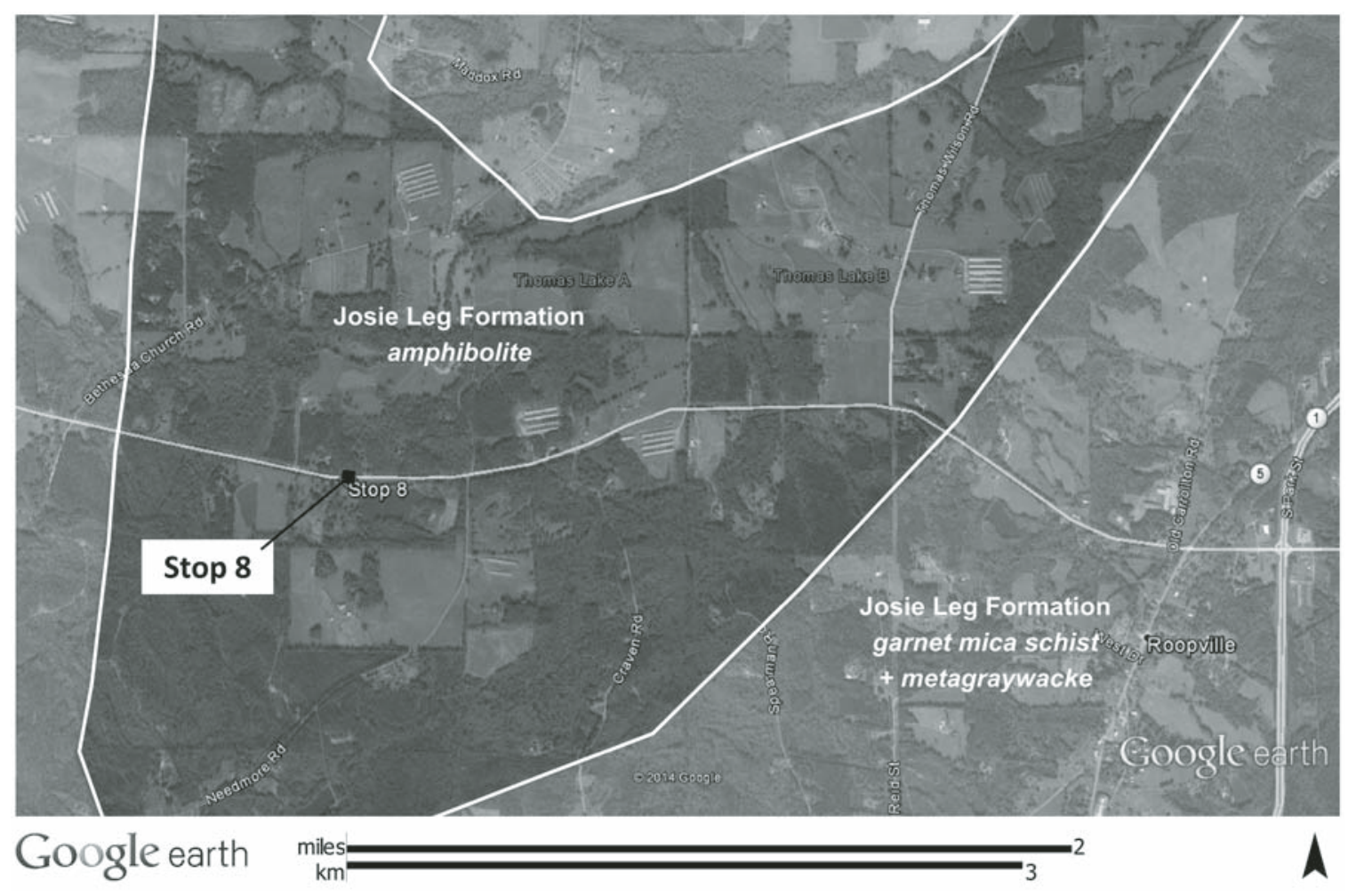

Figure 31. Location and generalized geology for Stop 8. 
- From the intersection of North Park Street and Alabama Street in downtown Carrollton, Georgia, drive north on North Park Street/GA S.R.-1/U.S.-27.

- After 8.1 miles, make a slight right (north) onto GA S.R.-113.

- After 9.3 miles, turn right (east) onto Interstate 20.

- Follow Interstate 20 east for 5 miles to exit 24 and exit to GA S.R.-101/GA S.R.-61 in Villa Rica, Georgia. At the end of the off ramp for exit 24, turn left onto S.R.-101/S.R.-61.

- After 0.7 miles on GA S.R.-101/GA S.R.-61, turn left on West Bankhead Hwy/GA S.R.-8/U.S.-78.

- After 0.4 miles, turn right on Villa Trace.

- Follow Villa Trace for 0.4 miles, then turn left on North Lassetter Circle. Stop 9 is a pavement outcrop of the Villa Rica Gneiss in a vacant lot on the right, immediately west of 919 North Lassetter Circle. Please obtain permission from property owner to view the Stop 9 exposure, if you are not traveling with the 2015 GSA field trip group.

\section{STOP 9 ( 30 min): Villa Rica Gneiss} $\left(33.735747^{\circ} \mathrm{N}, 84.949223^{\circ} \mathrm{W}\right)$

A large pavement exposure of the Villa Rica Gneiss is exposed at the north end of a vacant lot on North Lassetter Circle (Figs. 32 and 33). We thank Mr. Danny Waldrop for giving us permission to visit this outcrop. The Villa Rica Gneiss is a biotitequartz-plagioclase orthogneiss (Fig. 34) and was the main goldbearing unit in the Carroll County gold belt (German, 1989). The Villa Rica Gneiss has been assigned a U-Pb zircon age of $458 \pm 3 \mathrm{Ma}$ (Thomas, 2001) and provides an upper constraint on the age of deposition of the New Georgia Group. Because we consider rocks of the New Georgia Group to be stratigraphic equivalents of the Emuckfaw Group in Alabama, which contains ca. $460 \mathrm{Ma}$ detrital zircons, this suggests that much of the Emuckfaw/New Georgia Group sedimentary-volcanic package was deposited over an interval of only a few million years. Subsidence and sedimentation rates in back-arc basins (e.g., Sea of Japan) can exceed $750-900 \mathrm{~m} / \mathrm{m}$.y. during active spreading (Ingle, 1992), consistent with inferred rapid deposition of volcanic-sedimentary sequences in the WEDB.

- Turn around on North Lassetter Circle and return to Villa Trace. Turn right (south) on Villa Trace.

- After 0.4 miles, turn right (west) onto GA S.R.-8/U.S.-78.

- After 1.0 mile, turn right (north) on North Van Wert Road.

- After 3.1 miles, make a slight left (north) on GA S.R.-101.

- After 4.8 miles, turn right (east) on GA S.R.-120/ Buchanan Street.

- After 10.1 miles, make a slight right (east) onto West Memorial Drive/GA S.R.-6.

- After 1.1 miles, make a slight left (east) onto Memorial Drive/GA S.R.-381/Dallas-Acworth Highway.

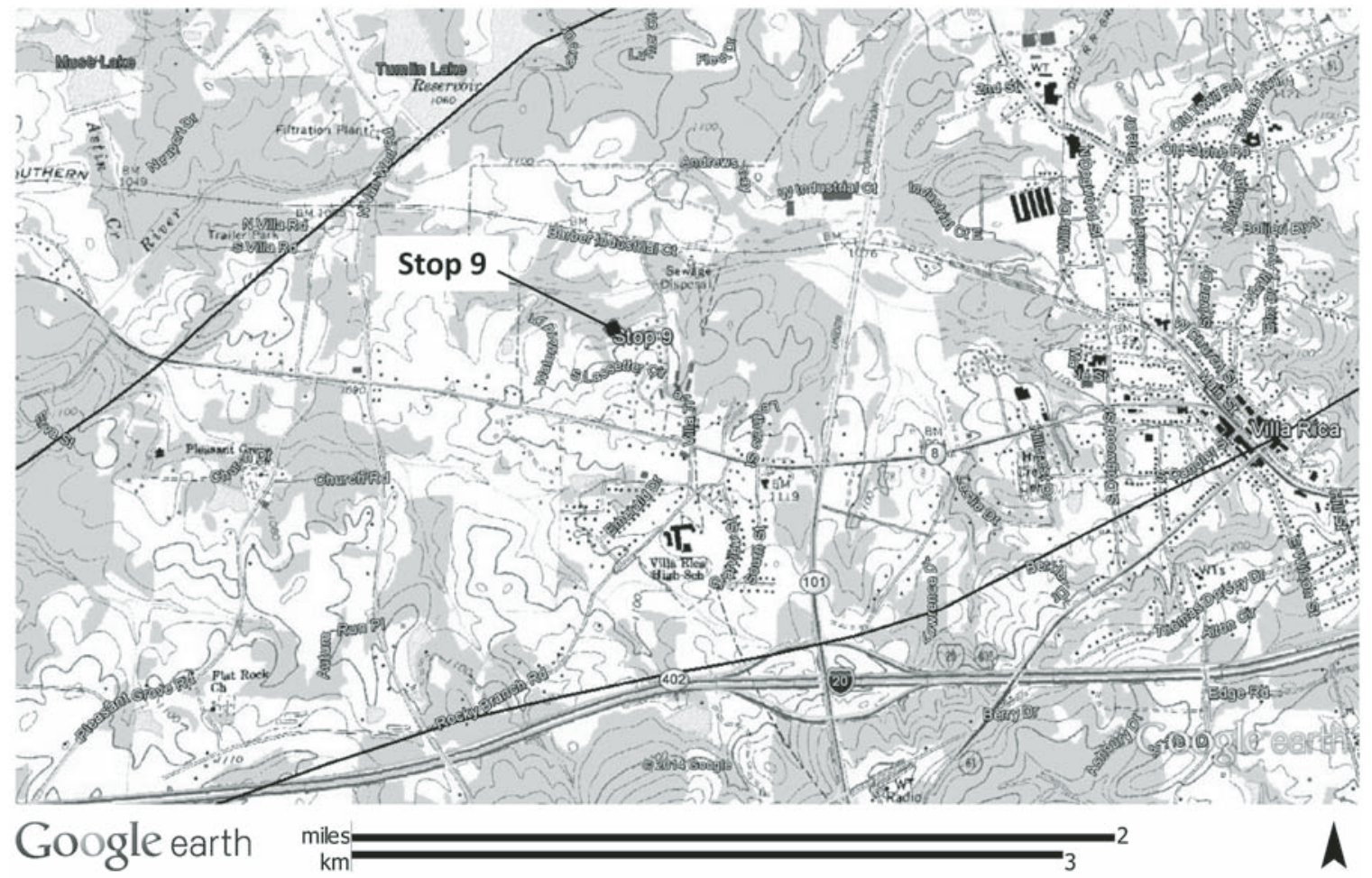

Figure 32. Location map for Stop 9 in Villa Rica, Georgia. 


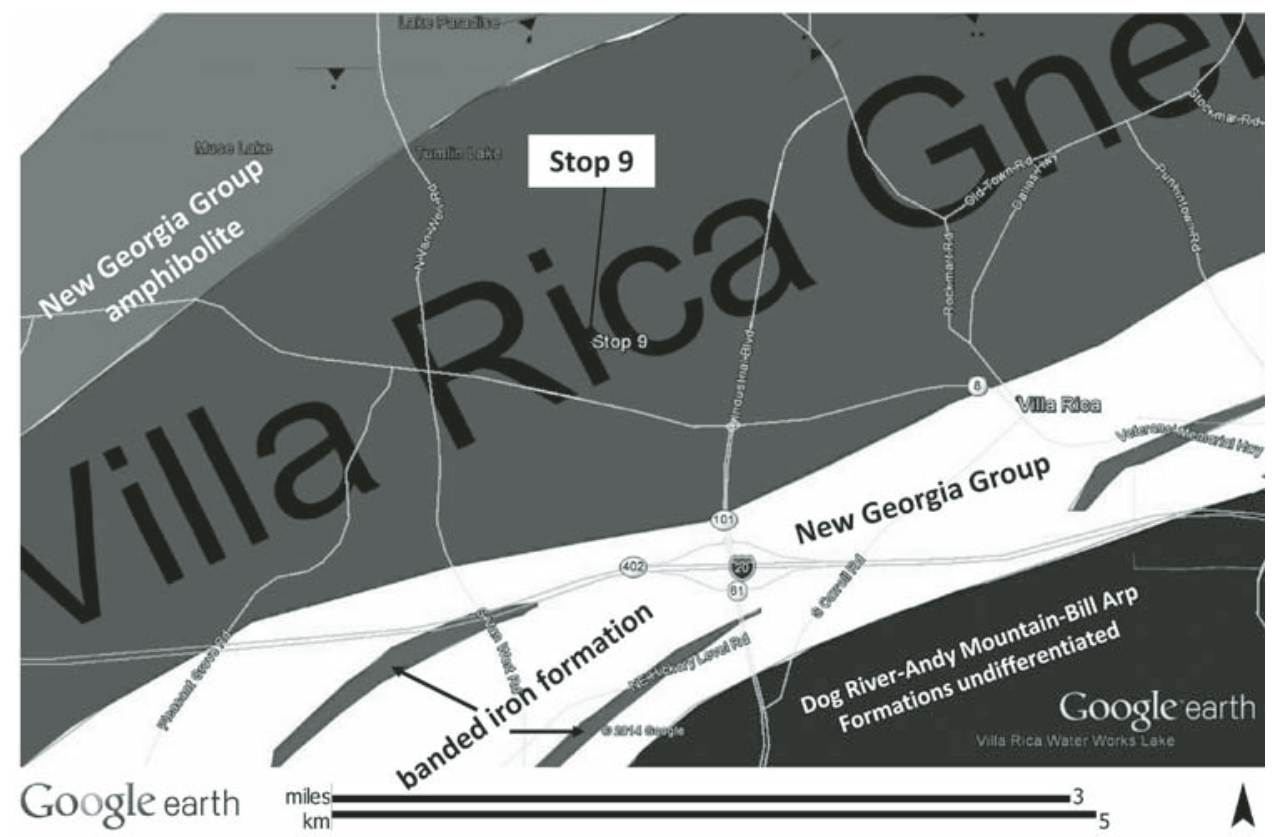

Figure 33. Geologic map for the region around Villa Rica, Georgia.
- After 11.5 miles, turn right (south) on GA S.R.-3/U.S.-41.

- After 1.5 miles, turn left (north) on GA S.R.-92/Lake Acworth Drive.

- After 3.7 miles, turn left (north) to stay on GA S.R.-92/ Cowan Road.

- After 3.5 miles, turn left (north) on Woodstock Road.

- After 1.7 miles, make a slight right on Victory Drive.

- After 1.0 mile, turn right (east) on Kellogg Creek Road. Kellogg Creek Road will immediately dead end into Bells Ferry Road. Turn left (north) on Bells Ferry Road.

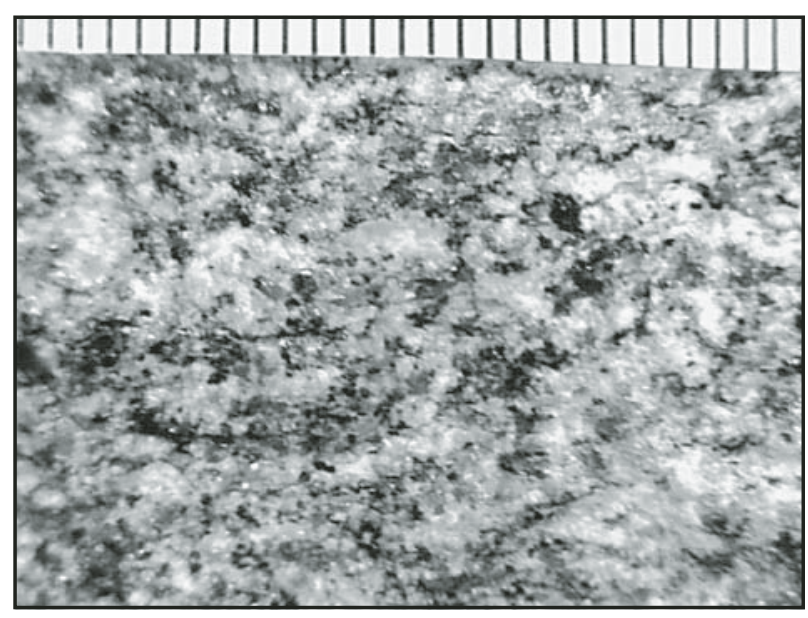

Figure 34. Villa Rica Gneiss exposed at Stop 9. Millimeterruled scale.
- After 2.9 miles, turn right into the Little River boat landing parking lot and park near the center of the lot. We will cross the road and hike a short distance uphill to a point overlooking the lake.

\section{STOP 10 ( 1 h): Pumpkinvine Creek Formation $\left(34.163398^{\circ} \mathrm{N}, 84.583055^{\circ} \mathrm{W}\right)$}

Rocks of the Pumpkinvine Creek Formation are exposed in a series of cliffs across (northwest side of) Bells Ferry Road (Fig. 35). A trail leading to the top of the hill provides excellent exposures of Pumpkinvine Creek Formation fine-grained chlorite-plagioclase-actinolite amphibolite and metafelsic lithologies. Deformed amphibolite can be easily observed at the top of the cliff at the northern end of this small promontory. The Pumpkinvine Creek Formation is between the Burnt Hickory Ridge fault at its structural top and the Allatoona fault at its structural base, with the Burnt Hickory Ridge fault separating it from rocks of the structurally higher New Georgia Group. In this region, however, the Chattahoochee fault has cut up-section through the Burnt Hickory Ridge fault, juxtaposing rocks of the Canton Formation with those of the structurally higher Chattahoochee thrust sheet (Fig. 36). The presence of a major structural discontinuity between the Pumpkinvine Creek Formation and the New Georgia Group precludes stratigraphic correlation. However, coeval igneous activity in both thrust sheets, abundant metagraywacke interlayered with amphibolite, and similarities in the geochemical character of both sediment and metamafic lithologies in both sections support our interpretation they both formed in the WEDB.

- Return to Chattanooga, Tennessee, from this location $(\sim 1.5 \mathrm{~h})$. 


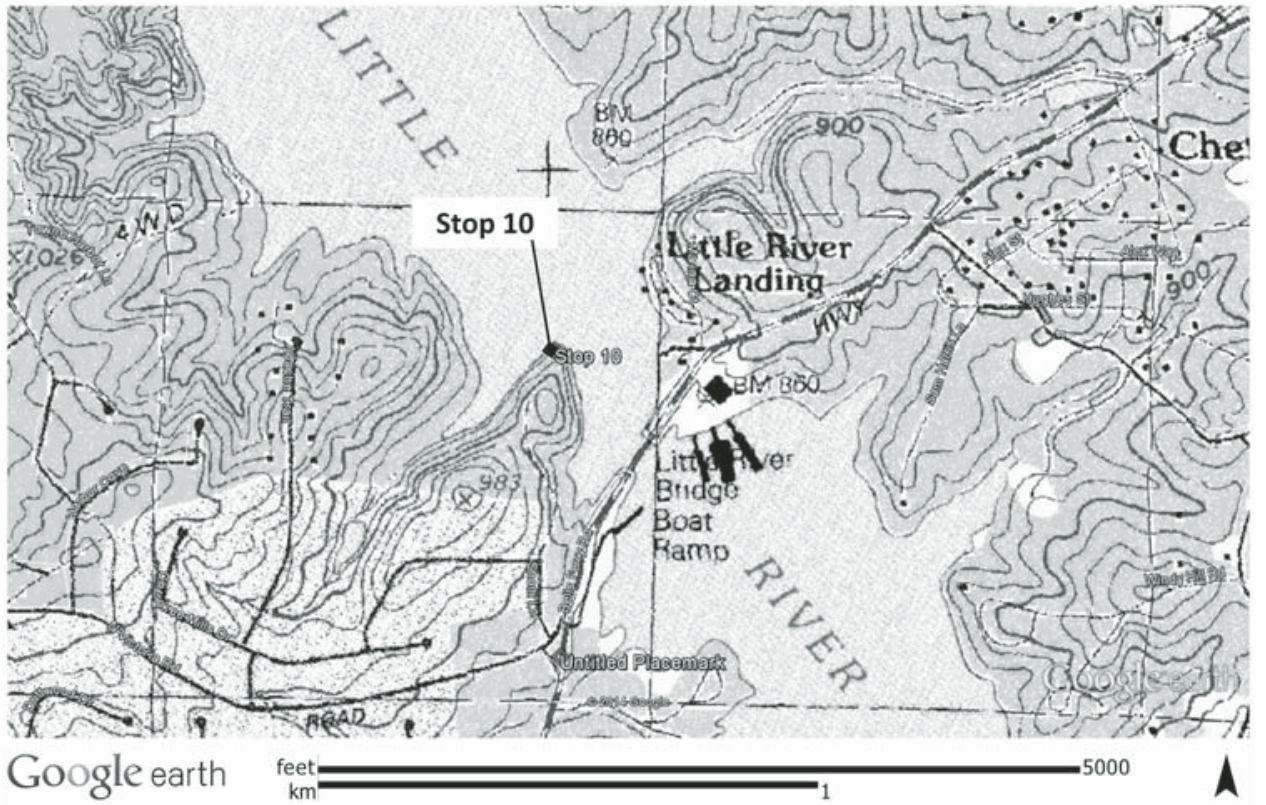

Figure 35. Location map for Stop 10.

\section{ACKNOWLEDGMENTS}

Research related to this study has been supported by the National Science Foundation (EAR-0309284 to J.F. Tull, and EAR1220540 to C.I. Barineau), the U.S. Geological Survey (USGS), National Cooperative Mapping Program (assistance awards 01HQAG0160, 02HQAG0100, 03HQAG0100, 04HQAG093, 05HQAG0107, 07HQAG0139, and G12AC20240 to J.F. Tull, and G11AC20184 to C.I. Barineau), and the USGS Mendenhall Postdoctoral Research Fellowship awarded to C.S. Holm-
Denoma. Jaime Azain (USGS) is thanked for her help with geochemical analyses. Jorge Vazquez is thanked for his help at the USGS-Stanford sensitive high-resolution ion microprobe (SHRIMP) laboratory, and Leonid Neymark (USGS) assisted with analyses at the USGS CMERSC LA-ICPMS laboratory. This manuscript is submitted for publication with the understanding that the U.S. government is authorized to reproduce and distribute reprints for governmental use. The views and conclusions contained in this document are those of the authors and should not be interpreted as necessarily representing the

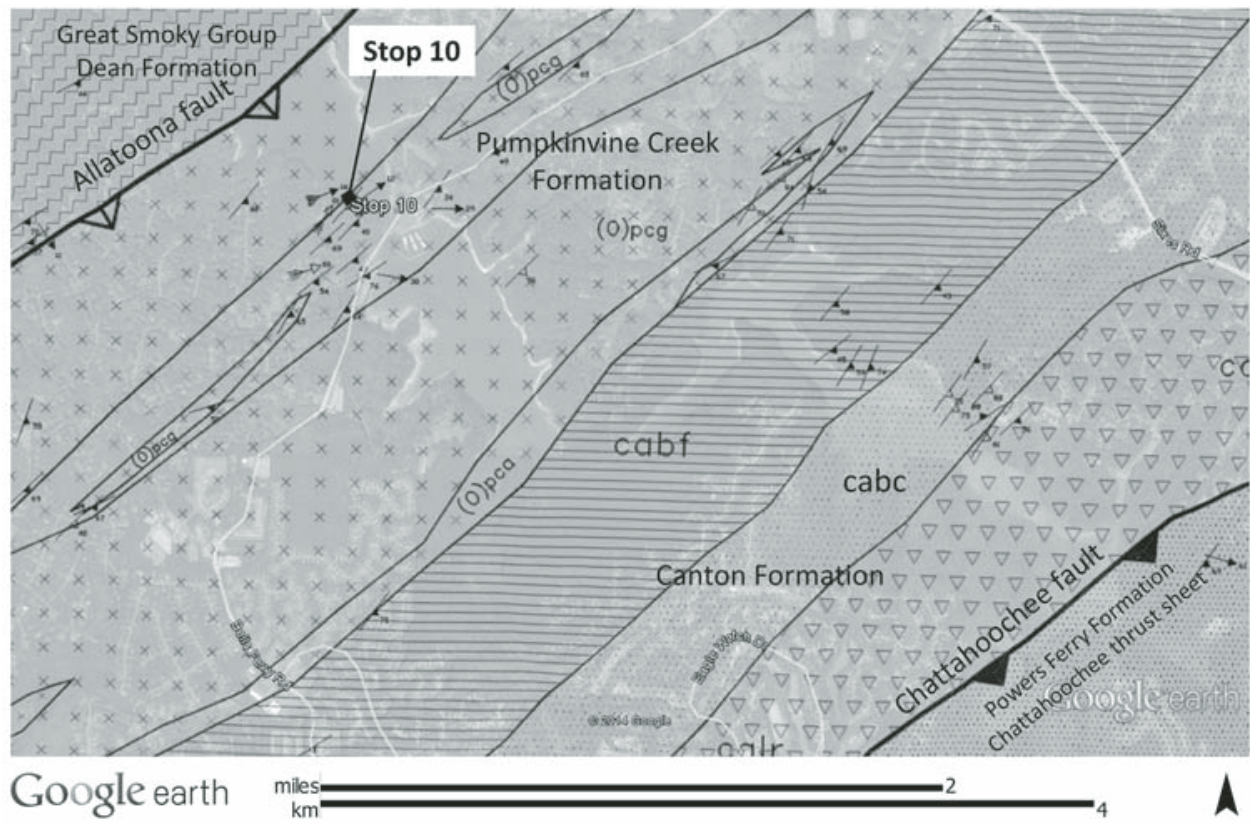

Figure 36. Geologic map for the area of Stop 10. After Holm-Denoma (2006). (O) pca-Ordovician Pumpkinvine Creek Formation amphibolite; (O)pcg-Ordovician Pumpkinevine Creek Formation gneiss; cabf-Canton Formation Bells Ferry Member; cabc-Canton Formation; calr-Canton Formation Little River Member. 
official policies, either expressed or implied, of the U.S. government. We would like to thank Scott Southworth, David Allison, and Ann Holmes for providing objective insightful reviews that improved the manuscript.

\section{REFERENCES CITED}

Abrams, C.E., and McConnell, K.I., 1984, Geologic setting of volcanogenic base and precious metal deposits of the West Georgia Piedmont: A multiply deformed metavolcanic terrain: Economic Geology and the Bulletin of the Society of Economic Geologists, v. 79, p. 1521-1539, doi:10.2113/ gsecongeo.79.7.1521.

Adams, G.I., 1926, The crystalline rocks, in Adams, G.I., Butts, C., Stephenson, L.W., and Cooke, C.W., eds., Geology of Alabama: Alabama Geological Survey Special Report 14, p. 25-40.

Adams, G.I., 1930, Gold deposits of Alabama and occurrences of copper, pyrite, arsenic, and tin: Alabama Geological Survey Bulletin 40, $91 \mathrm{p}$.

Ague, J.J., 2003, Fluid infiltration and transport of major, minor, and trace elements during regional metamorphism of carbonate rocks, Wepawaug Schist, Connecticut, USA: American Journal of Science, v. 303, p. 753816, doi:10.2475/ajs.303.9.753.

Ague, J.J., 2011, Extreme channelization of fluid and the problem of element mobility during Barrovian metamorphism: The American Mineralogist, v. 96, p. 333-352, doi:10.2138/am.2011.3582.

Aleinikoff, J.N., Zartman, R.E., Walter, M., Rankin, D.W., Lyttle, P.T., and Burton, W.C., 1995, U-Pb ages of metarhyolites of the Catoctin and Mount Rogers formations, Central and Southern Appalachians; evidence for two pulses of Iapetan rifting: American Journal of Science, v. 295, p. 428454, doi:10.2475/ajs.295.4.428.

Allison, D.T., 1992, Structural evolution and metamorphic petrogenesis of a metasediment and metaigneous complex, Coosa County, Alabama [Ph.D. dissertation]: Tallahassee, Florida State University, 378 p.

Allison, D.T., and Morisani, A., 2002, Using thermobarometry to detect fault ramp folding of Acadian isothermal and isobaric surfaces: An example from the Alabama eastern Blue Ridge Belt: Geological Society of America Abstracts with Programs, v. 34, no. 6, p. 432.

Anderson, E.D., and Moecher, D.P., 2009, Formation of high-pressure metabasites in the southern Appalachian Blue Ridge via Taconic continental subduction beneath the Laurentian margin: Tectonics, v. 28, TC5012, doi:10.1029/2008TC002319.

Argast, S., and Donnelly, T.W., 1987, The chemical discrimination of clastic sedimentary components: Journal of Sedimentary Petrology, v. 57, no. 5, p. 813-823.

Audley-Charles, M., 2004, Ocean trench blocked and obliterated by Banda forearc collision with Australian proximal continental slope: Tectonophysics, v. 389, p. 65-79, doi:10.1016/j.tecto.2004.07.048.

Barineau, C.I., 2009, Superposed fault systems of the southernmost Appalachian Talladega belt: Implications for Paleozoic orogenesis in the southern Appalachians [Ph.D. dissertation]: Tallahassee, Florida State University, 136 p.

Barineau, C.I., and Tull, J.F., 2012, The Talladega and Ashland-WedoweeEmuckfaw Belts of Alabama: Geological overview, in Barineau, C.I., and Tull, J.F., eds., The Talladega Slate Belt and Eastern Blue Ridge: Laurentian Plate Passive Margin to Back-Arc Basin Tectonics in the Southern Appalachian Orogen: Tuscaloosa, Alabama Geological Society, 49th Annual Field Trip Guidebook, p. 1-11.

Barineau, C.I., Tull, J.F., and Woodall, J.D., 2012, Strain analysis on the subLay Dam unconformity near Jumbo, Alabama, in Barineau, C.I., and Tull, J.F., eds., The Talladega Slate Belt and Eastern Blue Ridge: Laurentian Plate Passive Margin to Back-Arc Basin Tectonics in the Southern Appalachian Orogen: Tuscaloosa, Alabama Geological Society, 49th Annual Field Trip Guidebook, p. 38-46.

Bayona, G., and Thomas, W.A., 2003, Distinguishing fault reactivation from flexural deformation in the distal stratigraphy of the peripheral Blountian foreland basin, southern Appalachians, USA: Basin Research, v. 15, p. 503-526, doi:10.1046/j.1365-2117.2003.00217.x.

Bayona, G., and Thomas, W.A., 2006, Influence of pre-existing plate-margin structures on foredeep filling: Insights from the Taconian (Blountain) clastic wedge, southeastern USA: Sedimentary Geology, v. 191, p. 115133, doi:10.1016/j.sedgeo.2006.02.001.
Beaumont, C., Quinlan, G., and Hamilton, J., 1988, Orogeny and stratigraphy: Numerical models of the Paleozoic in the eastern interior of North America: Tectonics, v. 7, p. 389-416, doi:10.1029/TC007i003p00389.

Beck, C.B., 1978, Periastron reticulatum Unger and Aerocortex kentuckiensis, n. gen. et sp., from the New Albany Shale of Kentucky: American Journal of Botany, v. 65, p. 221-235, doi:10.2307/2442456.

Becker, T.P., Thomas, W.A., Samson, S.D., and Gehrels, G.E., 2005, Detrital zircon evidence of Laurentian crustal dominance in the Lower Pennsylvanian deposits of the Alleghanian clastic wedge in eastern North America; isotopic determination of sediment provenance: Techniques and applications: Sedimentary Geology, v. 182, p. 59-86, doi:10.1016/j sedgeo.2005.07.014.

Bennett, V.C., and DePaolo, D.J., 1987, Proterozoic crustal history of the western United States as determined by neodymium isotopic mapping (with suppl. data 87-30): Geological Society of America Bulletin, v. 99, p. 674 685, doi:10.1130/0016-7606(1987)99<674:PCHOTW>2.0.CO;2.

Bentley, R.D., and Neathery, T.L., eds., 1970, Geology of the Brevard Fault Zone and Related Rocks of the Inner Piedmont of Alabama: 8th Annual Field Trip of the Alabama Geological Society: Tuscaloosa, Alabama Geological Society, no. 8, 119 p.

Bhatia, M.R., 1983, Plate tectonics and geochemical compositions of sandstones: The Journal of Geology, v. 91, p. 611-627, doi:10.1086/628815.

Bhatia, M.R., 1985, Rare earth element geochemistry of Australian Paleozoic graywackes and mudrocks: Provenance and tectonic control: Sedimentary Geology, v. 45, p. 97-113, doi:10.1016/0037-0738(85)90025-9.

Bhatia, M.R., and Crook, K.A.W., 1986, Trace element characteristics of greywackes and tectonic setting discrimination of sedimentary basins: Contributions to Mineralogy and Petrology, v. 92, p. 181-193, doi:10.1007/BF00375292.

Bieler, D.B., and Deininger, R.W., 1987, Geologic setting of the Koweliga Augen Gneiss and the Zana Granite, northwestern Alabama piedmont, in Drummond, M.S., and Green, N.L., eds., Granites of Alabama: Tuscaloosa, Alabama, Geological Survey of Alabama, p. 57-72.

Bird, J.M., and Dewey, J.F., 1970, Lithosphere plate-continental margin tectonics and the evolution of the Appalachian orogen: Geological Society of America Bulletin, v. 81, no. 4, p. 1031-1060, doi:10.1130/0016 -7606(1970)81[1031:LPMTAT]2.0.CO;2.

Bream, B.R., 2003, Tectonic implications of para- and orthogneiss geochronology and geochemistry from the Southern Appalachian crystalline core [Ph.D. thesis]: Knoxville, University of Tennessee, 310 p.

Bream, B.R., Hatcher, R.D., Jr., Miller, C.F., and Fullagar, P.D., 2004, Detrital zircon ages and $\mathrm{Nd}$ isotopic data from the southern Appalachian crystalline core, Georgia, South Carolina, North Carolina, and Tennessee: New provenance constraints for part of the Laurentian margin, in Tollo, R.P., McLelland, J., Corriveau, L., and Bartholomew, M.J., eds., Proterozoic Tectonic Evolution of the Grenville Orogen in North America: Geological Society of America Memoir 197, p. 459-475.

Brown, D.E., and Cook, R.B., 1981, Petrography of major Dadeville complex rock units in the Boyds Creek area, Chambers and Lee Counties, Alabama, in Sears, J.W., ed., Contrasts in Tectonic Style between the Inner Piedmont Terrane and the Pine Mountain Window: Tuscaloosa, Alabama Geological Society, 18th Annual Field Trip Guidebook, p. 15-40.

Butts, C., 1926, The Paleozoic rocks, in Adams, G.I., et al., eds., Geology of Alabama: Alabama Geological Survey Special Report, v. 14, p. 40-223.

Butts, C., 1940, Description of the Montevallo and Columbiana Quadrangles: U.S. Geological Survey Atlas: Folio, v. 226, p. 1-19.

Cabanis, B., and Lecolle, M., 1989, Le diagramme La/10-Y/15-Nb/8; un outil pour la discrimination des séries volcaniques et la mise en évidence des processus de mélange et/ou de contamination crustale: Comptes Rendus de l'Académie des Sciences, ser. 2A, Sciences de la Terre et des Planètes, v. 309, p. 2023-2029.

Carrington, T.J., 1973, Metamorphosed Paleozoic sedimentary rocks in Chilton, Shelby, and Talladega Counties, Alabama, in Carrington, T.J., ed., Talladega Metamorphic Front: Alabama Geological Society, 11th Annual Field Trip Guidebook, p. 22-38.

Carter, W.W., Jr., 1985, Geology of Cedar and Talladega mountains, Clay County, Alabama [Ph.D. thesis]: Tuscaloosa, Alabama, University of Alabama at Tuscaloosa, p. 132.

Cawood, P.A., Kröner, A., Collins, W.J., Kusky, T.M., Mooney, W.D., and Windley, B.F., 2009, Accretionary orogens through Earth history, in Cawood, P.A., and Kröner, A., eds., Earth Accretionary Systems in Space and Time: Geological Society, London, Special Publication 318, p. 1-36, doi:10.1144/SP318.1. 
Chapple, W.M., 1973, Taconic orogeny; abortive subduction of the North American continental plate? Geological Society of America Abstracts with Programs, v. 5, no. 5, p. 573.

Clark, J.R., 1973, Petrology and geochemistry of the Seroyer Branch maficultramafic complex, Chambers County, Alabama: Geological Society of America Abstracts with Programs, v. 5, no. 5, p. 387.

Clemons, K.M., and Moecher, D.P., 2009, Re-interpretation of the deformation history of the Greenbrier fault, Great Smoky Mountains: Petrologic, structural, and geochemical constraints: Geological Society of America Bulletin, v. 121, p. 1108-1122, doi:10.1130/B26480.1.

Cloos, M., Sapiie, B., Ufford, A.Q. van, Weiland, R.J., Warren, P.Q., and McMahon, T.P., 2005, Collisional Delamination in New Guinea: The Geotectonics of Subducting Slab Breakoff: Geological Society of America Special Paper 400, $51 \mathrm{p}$.

Cluzel, D., Aitchison, J.C., and Picard, C., 2001, Tectonic accretion and underplating of mafic terranes in the Late Eocene intraoceanic fore-arc of New Caledonia (Southwest Pacific): Geodynamic implications: Tectonophysics, v. 340, no. 1-2, p. 23-59, doi:10.1016/S0040-1951(01)00148-2.

Coakley, B., and Gurnis, M., 1995, Far-field tilting of Laurentia during the Ordovician and constraints on the evolution of a slab under an ancient continent: Journal of Geophysical Research, v. 100, p. 6313-6327.

Cocks, L.R.M., and Torsvik, T.H., 2002, Earth geography from 500 to 400 million years ago: A faunal and palaeomagnetic review: Journal of the Geological Society, London, v. 159, no. 6, p. 631-644, doi:10.1144/0016 -764901-118.

Cohen, K.M., Finney, S.C., Gibbard, P.L., and Fan, J.-X., 2013, The ICS International Chronostratigraphic Chart: Episodes, v. 36, no. 3, p. 199-204.

Colberg, M.R., and Chalokwu, C.I., 1990, Field, textural and chemical characteristics of migmatites in the Auburn Gneiss, Lee County, Alabama: Implications for petrogenesis: A guidebook for Field Trip VII, in Steltenpohl, M.G., Kish, S.A., and Neilson, M.J., eds., Geology of the Southern Inner Piedmont, Alabama and Southwest Georgia: Geological Society of America Southeastern Section, p. 43-58.

Collins, W.J., 2002, Hot orogens, tectonic switching, and creation of continental crust: Geology, v. 30, p. 535-538, doi:10.1130/0091-7613 (2002)030<0535:HOTSAC >2.0.CO;2.

Corrie, S.L., and Kohn, M.J., 2007, Resolving the timing of orogenesis in the Western Blue Ridge, southern Appalachians, via in situ ID-TIMS monazite geochronology: Geology, v. 35, p. 627-630, doi:10.1130/G23601A.1.

Crawford, T.F., and Medlin, J.H., 1974, Brevard Fault Zone in Western Georgia and Eastern Alabama: Georgia Geological Survey Guidebook, v. 12, p. 1-67.

Creaser, R.A., Erdmer, P., Stevens, R.A., and Grant, S.L., 1997, Tectonic affinity of Nisutlin and Anvil assemblage strata from the Teslin tectonic zone, northern Canadian Cordillera: Constraints from neodymium isotope and geochemical evidence: Tectonics, v. 16, p. 107-121, doi:10.1029/96TC03317.

Cressler, C.W., 1970, Geology and Ground-Water Resources of Floyd and Polk Counties, Georgia: Geological Survey of Georgia Information Circular $39,95 \mathrm{p}$.

Davies, G.R., and MacDonald, R., 1987, Crustal influences in the petrogenesis of the Naivasha basalt-rhyolite complex: Combined trace element and Sr-Nd-Pb isotope constraints: Journal of Petrology, v. 28, p. 1009-1031, doi:10.1093/petrology/28.6.1009.

Davis, T.L., 1993, Lithostratigraphy, structure, and metamorphism of a crystalline thrust terrane, Western Inner Piedmont, North Carolina [Ph.D. thesis]: Knoxville, Tennessee, University of Tennessee, 245 p.

Das, R., 2006, Geochemical and geochronological investigations in the southern Appalachians, southern Rocky Mountains and Deccan Traps [Ph.D. thesis]: Tallahassee, Florida State University, 159 p.

De Franco, R., Govers, R., and Wortel, R., 2008, Nature of the plate contact and subduction zones diversity: Earth and Planetary Science Letters, v. 271, no. $1-4$, p. $245-253$, doi:10.1016/j.eps1.2008.04.019.

Diecchio, R.J., 1993, Stratigraphic interpretation of the Ordovician of the Appalachian basin and implications for Taconian flexural modeling: Tectonics, v. 12, no. 6, p. 1410-1419, doi:10.1029/93TC01791.

Drake, A.A., Jr., Sinha, A.K., Laird, J., and Guy, R.E., 1989, The Taconic Orogen, in Hatcher, R.D., Jr., Thomas, W.A., and Viele, G.W., eds., The AppalachianOuachita Orogen in the United States: Boulder, Colorado, Geological Society of America, Geology of North America, v. F-2, p. 101-177.

Drummond, M.S., 1986, Igneous, metamorphic, and structural history of the Alabama Tin Belt, Coosa County, Alabama [Ph.D. dissertation]: Tallahassee, Florida State University, 411 p.
Drummond, M.S., Wesolowski, D.J., and Allison, D.T., 1988, Generation, diversification, and emplacement of the Rockford Granite, Alabama Appalachians; mineralogic, petrologic, isotopic $(\mathrm{C} \& \mathrm{O})$, and P-T constraints: Journal of Petrology, v. 29, p. 869-897, doi:10.1093/petrology/29.4.869.

Drummond, M.S., Allison, D.T., and Wesolowski, D.J., 1994, Igneous petrogenesis and tectonic setting of the Elkahatchee Quartz Diorite, Alabama Appalachians; implications for Penobscotian magmatism in the eastern Blue Ridge: American Journal of Science, v. 294, p. 173-236, doi:10.2475/ajs.294.2.173.

Drummond, M.S., Neilson, M.J., Allison, D.T., and Tull, J.F., 1997, Igneous petrogenesis and tectonic setting of granitic rocks from the eastern Blue Ridge and Inner Piedmont, Alabama Appalachians, in Sinha, A.K., Whalen, J.B., and Hogan, J.P., eds., The Nature of Magmatism in the Appalachian Orogen: Geological Society of America Memoir 191, p. $147-164$.

Durand, C., Marquer, D., Baumgartner, L.P., Goncalves, P., Boulvais, P., and Rossy, M., 2009, Large calcite and bulk-rock volume loss in metacarbonate xenoliths from the Quérigut massif (French Pyrenees): Contributions to Mineralogy and Petrology, v. 157, p. 749-763, doi:10.1007/s00410 $-008-0362-5$.

El-Shazly, A.K., Loehn, C., and Tracy, R.J., 2011, P-T-t evolution of granulite facies metamorphism and partial melting in the Winding Stair Gap, Central Blue Ridge, North Carolina, USA: Journal of Metamorphic Geology, v. 29 , no. 7, p.753-780.

Ettensohn, F.R., 2004, Modeling the nature and development of major Paleozoic clastic wedges in the Appalachian Basin, USA: Journal of Geodynamics, v. 37, p. 657-681, doi:10.1016/j.jog.2004.02.009.

Evans, J.A., Zalasiewicz, J.A., Fletcher, I., Rasmussen, B., and Pearce, N.J., 2002, Dating diagenetic monazite in mudrocks: Constraining the oil window?: Journal of the Geological Society, London, v. 159, no. 6, p. 619622, doi:10.1144/0016-764902-066.

Fergusson, C.L., 2003, Ordovician-Silurian accretion tectonics of the Lachlan Fold Belt, southeastern Australia: Australian Journal of Earth Sciences, v. 50, p. 475-490, doi:10.1046/j.1440-0952.2003.01013.x.

Finney, S.C., Grubb, B.J., and Hatcher, R.D., Jr., 1996, Graphic correlation of Middle Ordovician graptolite shale, southern Appalachians: An approach for examining the subsidence and migration of a Taconic foreland basin: Geological Society of America Bulletin, v. 108, no. 3, p. 355-371, doi:10.1130/0016-7606(1996)108<0355:GCOMOG >2.3.CO;2.

Foster, D.A., and Gray, D.R., 2000, Evolution and structure of the Lachlan Fold Belt (Orogen) of Eastern Australia: Annual Review of Earth and Planetary Sciences, v. 28, p. 47-80, doi:10.1146/annurev.earth.28.1.47.

Franklin, J.M., Gibson, H.L., Jonasson, I.R., and Galley, A.G., 2005, Volcanogenic massive sulfide deposits, in Hedenquist, J.W., Thompson, J.F.H., Goldfarb, R.J., and Richards, J.P., eds., Economic Geology, 100th Anniversary Volume, 1905-2005: Littleton, Colorado, Society of Economic Geologists, p. 523-560.

Garofalo, P.S., 2012, The composition of Alpine marine sediments (Bündnerschiefer Formation, W Alps) and the mobility of their chemical components during orogenic metamorphism: Lithos, v. 128-131, p. 55-72, doi:10.1016/j.lithos.2011.10.009

Gastaldo, R.A., 1995, New occurrence of Periastron reticulatum Unger emend. Beck, an enigmatic Mississippian fossil plant: Journal of Paleontology, v. 69, p. $388-392$.

German, J.M., 1985, The Geology of the Northeastern Portion of the Dahlonega Gold Belt: Georgia Geological Survey Bulletin 100, 41 p.

German, J.M., 1988, The Geology of Gold Occurrences in the West-Central Georgia Piedmont: The Carroll County Gold Belt and the Southwestern Portion of the Dahlonega Gold Belt: Atlanta, Georgia Department of Natural Resources, Environmental Protection Division, Georgia Geologic Survey Bulletin, v. 107, 48 p.

German, J.M., 1989, Geologic setting and genesis of gold deposits of the Dahlonega and Carroll County gold belts, Georgia: Economic Geology and the Bulletin of the Society of Economic Geologists, v. 84, p. 903-923, doi:10.2113/gsecongeo.84.4.903.

Gibson, G.M., 1992, Medium-high-pressure metamorphic rocks of the Tuhua Orogen, western New Zealand, as lower crustal analogues of the Lachlan Fold Belt, SE Australia: Tectonophysics, v. 214, no. 1-4, p. 145-157, doi:10.1016/0040-1951(92)90194-B.

Gillon, K.A., 1982, Stratigraphic, structural and metamorphic geology of portions of the Cowrock and Helen, Georgia quadrangles [M.S. thesis]: Athens, Georgia, University of Georgia, $236 \mathrm{p}$. 
Gillon, K.A., 1989, The geology of the eastern Blue Ridge thrust sheets in the vicinity of Helen, Georgia, in Fritz, W.J., Hatcher, R.D., Jr., and Hopson, J.L. eds., Georgia Geological Society Guidebook, v. 9, p. 133-169.

Gillon, K.A., 2001, The Dahlonega gold belt and Hillabee Greenstone: Evidence for fast-paced Taconic tectonism in the eastern Blue Ridge: Geological Society of America Abstracts with Programs, v. 33, no. SE, p. 66.

Gilmer, J.J., and Barineau, C.I., 2012, Correlation of Ashland-WedoweeEmuckfaw Belt and Dahlonega gold belt stratigraphy, northwestern Georgia-northeastern Alabama, southern Appalachians: Geological Society of America Abstracts with Programs, v. 44, no. 4, p. 22.

Goldberg, S.A., and Steltenpohl, M.G., 1990, Timing and characteristics of Paleozoic deformation and metamorphism in the Alabama Inner Piedmont: American Journal of Science, v. 290, no. 10, p. 1169-1200, doi:10.2475/ajs.290.10.1169.

Gray, D.R., and Foster, D.A., 1997, Orogenic concepts; application and definition; Lachlan fold belt, eastern Australia: American Journal of Science, v. 297, p. 859-891, doi:10.2475/ajs.297.9.859.

Gray, D.R., and Foster, D.A., 1998, Character and kinematics of faults within the turbidite-dominated Lachlan Orogen: Implications for tectonic evolution of eastern Australia: Journal of Structural Geology, v. 20, p. 16911720, doi:10.1016/S0191-8141(98)00089-3.

Gray, D.R., and Foster, D.A., 2004, Tectonic evolution of the Lachlan Orogen, southeast Australia: Historical review, data synthesis and modern perspectives: Australian Journal of Earth Sciences, v. 51, no. 6, p. 773-817, doi:10.1111/j.1400-0952.2004.01092.x.

Grimes, J.E., Steltenpohl, M.G., Cook, R.B., Jr., and Keefer, W.D., 1993, New geological studies of the most southern part of the Brevard zone, Alabama, and their implications for southern Appalachian tectonostratigraphy, in Steltenpohl, M.G., and Salpas, P.A., eds., Geology of the Southernmost Exposed Appalachian Piedmont Rocks along the Alabama Fall Line: Southeastern Section of the Geological Society of America Field Trip Guidebook, p. 95-116.

Gurnis, M., Hall, C., and Lavier, L., 2004, Evolving force balance during incipient subduction: Geochemistry Geophysics Geosystems, v. 5, Q07001, doi:10.1029/2003GC000681.

Guthrie, G.M., and Dean, L., 1989, Geology of the New Site 7.5-Minute Quadrangle, Tallapoosa and Clay Counties, Alabama: Geological Survey of Alabama Quadrangle Series Map 9, 41 p.

Hall, C.E., Gurnis, M., Sdrolias, M., Lavier, L.L., and Mueller, R.D., 2003, Catastrophic initiation of subduction following forced convergence across fracture zones: Earth and Planetary Science Letters, v. 212, p. 15-30, doi: $10.1016 / \mathrm{S} 0012-821 \mathrm{X}(03) 00242-5$.

Harris, R., 2006, Rise and fall of the Eastern Great Indonesian arc recorded by the assembly, dispersion and accretion of the Banda Terrane, Timor: Gondwana Research, v. 10, p. 207-231, doi:10.1016/j.gr.2006.05.010.

Harris, R.A., Sawyer, R.K., and Audley-Charles, M.G., 1998, Collisional melange development: Geologic associations of active melange-forming processes with exhumed melange facies in the western Banda orogen, Indonesia: Tectonics, v. 17, p. 458-479, doi:10.1029/97TC03083.

Harstad, R.P., and Barineau, C.I., 2014, Kinematic and age constraints on the Alexander City fault, eastern Blue Ridge, Alabama: Geological Society of America Abstracts with Programs, v. 46, no. 6, p. 504.

Hatcher, R.D., Jr., 1972, Developmental model for the southern Appalachians: Geological Society of America Bulletin, v. 83, no. 9, p. 2735-2760, doi:10.1130/0016-7606(1972)83[2735:DMFTSA]2.0.CO;2.

Hatcher, R.D., Jr., 1988, Bedrock geology and regional geologic setting of Coweeta Hydrologic Laboratory in the eastern Blue Ridge, with some discussion of Quaternary deposits and structural controls of topography, in Swank, W.T., and Crossley, D.A., eds., Cowetta Symposium 66: New York, Springer-Verlag, p. 81-92.

Hatcher, R.D., Jr., 1987, Tectonics of the southern and central Appalachian internides: Annual Review of Earth and Planetary Sciences, v. 15, p. 337 362, doi:10.1146/annurev.ea.15.050187.002005.

Hatcher, R.D., Jr., 1989, Tectonic synthesis of the U.S. Appalachians, in Hatcher, R.D., Jr., Thomas, W.A., and Viele, G.W. eds., The AppalachianOuachita Orogen in the United States: Boulder, Colorado, Geological Society of America, Geology of North America, v. F-2, p. 511-535.

Hatcher, R.D., Jr., 2005, North America; Southern and Central Appalachians, in Selley, R.C., Cocks, L.R.M., and Plimer, I.R., eds., Encyclopedia of Geology; Volume 4: Oxford, UK, Elsevier Academic Press.

Hatcher, R.D., Jr., 2008, Nature of the Talladega Front in the Sylacauga area, Alabama, in Higgins, M.W., Crawford, R.F. and Hatcher, R.D., Jr., eds.,
Alternative Interpretations of the Talladega Slate Belt, Alabama and Georgia: Guidebook for the 45th Annual Field Trip of the Alabama Geological Society, p. 30-42.

Hatcher, R.D., Jr., Bream, B.R., and Merschat, A.J., 2007, Tectonic map of the southern and central Appalachians: A tale of three orogens and a complete Wilson Cycle, in Hatcher, R.D., Jr., Carlson, M.P., McBride, J.H., and Martínez Catalán, J.R., eds., 4-D Framework of Continental Crust: Geological Society of America Memoir 200, p. 595-632.

Haynes, J.T., Huff, W.D., and Melson, W.G., 2011, Major Ordovician tephras generated by caldera-forming explosive volcanism on continental crust: Evidence from biotite compositions, in Gutiérrez-Marco, J.C., Rábano, I., and García-Bellido, D., eds., Ordovician of the World: Cuadernos del Museo Geominero, 14: Madrid, Spain, Instituto Geológico y Minero de España, p. 229-235

Hawkins, J.F., Steltenpohl, M.G., Zou, H., Mueller, P.M., and Schwartz, J.J., 2013, New constraints on Ordovician magmatism in the southernmost exposures of the eastern Blue Ridge in Alabama: Geological Society of America Abstracts with Programs, v. 45, no. 2, p. 62.

Higgins, M.W., and McConnell, K.I., 1978, The Sandy Springs Group and related rocks of the Georgia Piedmont: Nomenclature and stratigraphy: Georgia Geological Survey Bulletin, v. 93, p. 50-55.

Higgins, M.W., Atkins, R.L., Crawford, T.J., Crawford, R.F., III, Brooks, R., and Cook, R.B., Jr., 1988, The Structure, Stratigraphy, Tectonostratigraphy, and Evolution of the Southernmost Part of the Appalachian Orogen: U.S. Geological Survey Professional Paper 1475, 173 p.

Higgins, M.W., Arth, J.G., Wooden, J.L., Crawford, T.J., Stern, T.W., and Crawford, R.F., 1997, Age and origin of the Austell Gneiss, western Georgia Piedmont-Blue Ridge, and its bearing on the ages of orogenic events in the southern Appalachians, in Sinha, A.K., Whalen, J.B., and Hogan, J.P., eds., The Nature of Magmatism in the Appalachian Orogen: Geological Society of America Memoir 191, p. 181-192.

Higgins, M.W., Crawford, R.F., and Steltenpohl, M.G., 2011, The dog river window-A major feature of the Blue Ridge in western Georgia and the piedmont in Alabama: Geological Society of America Abstracts with Programs, v. 43 , no. 2 , p. 15 .

Holm-Denoma, C.S., 2006, Characterization of Paleozoic terranes and terrane accretion at the southeastern margin of Laurentia: Georgia and Alabama Appalachians [Ph.D. thesis]: Tallahassee, Florida State University, 135 p.

Holm-Denoma, C.S., and Das, R., 2010, Bimodal volcanism as evidence for Paleozoic extensional accretionary tectonism in the southern Appalachians: Geological Society of America Bulletin, v. 122, p. 1220-1234, doi:10.1130/B30051.1

Honthaas, C., Réhault, J., Maury, R.C., Bellon, H., Hémond, C., Malod, J., Cornée, J., Villeneuve, M., Cotten, J., Burhanuddin, S., Guillou, H., and Arnaud, N., 1998, A Neogene back-arc origin for the Banda Sea basins: Geochemical and geochronological constraints from the Banda ridges (East Indonesia): Tectonophysics, v. 298, p. 297-317, doi:10.1016/S0040-1951(98)00190-5.

Hopson, J.L., 1989, Structure, stratigraphy, and petrogenesis of the Lake Burton mafic-ultramafic complex, in Fritz, W.J., Hatcher, R.D., Jr., and Hopson, J.L, eds., Georgia Geological Society Guidebook, v. 9, p. 93-110.

Huang, C., Yuan, P.B., and Tsao, S., 2006, Temporal and spatial records of active arc-continent collision in Taiwan; a synthesis: Geological Society of America Bulletin, v. 118, p. 274-288, doi:10.1130/B25527.1.

Huff, W.D., Bergstrom, S.M., Kolata, D.R., 1992, Gigantic Ordovician volcanic ash fall in North America and Europe: Biological, tectonomagmatic, and event-stratigraphic significance: Geology, v. 20, p. 875-878.

Hurst, V.J., and Jones, L.M., 1973, Origin of amphibolites in the CartersvilleVilla Rica area, Georgia: Geological Society of America Bulletin, v. 84, p. 905-911, doi:10.1130/0016-7606(1973)84<905:OOAITC >2.0.CO;2.

Hutchinson, R.W., 1980, Massive base metal sulfide deposits as guides to tectonic evolution, in Strangway, D.W., ed., The Continental Crust and Its Mineral Deposits: Geological Association of Canada Special Paper 20, p. 659-684.

Ingle, J.C., Jr., 1992, Subsidence of the Japan Sea: Stratigraphic evidence from ODP sites and onshore sections, in Proceedings of the Ocean Drilling Program, Scientific Results, v. 127, p. 1197-1218.

Ingram, S.B., III, 2012, U-Pb zircon and monazite geochronology and hafnium isotopic geochemistry of Neoacadian and early Alleghanian plutonic rocks in the Alabama eastern Blue Ridge, southern Appalachian Mountains [Master's thesis]: Tuscaloosa, Alabama, University of Alabama, $79 \mathrm{p}$.

Irvine, T.N., and Barrager, W.R.A., 1971, A guide to the chemical classification of the common volcanic rocks: Canadian Journal of Earth Sciences, v. 8, p. 523-548, doi:10.1139/e71-055. 
Ishibashi, J., and Urabe, T., 1995, Hydrothermal activity related to arc-backarc magmatism in the western Pacific, in Taylor, B., ed., Backarc Basins: Tectonics and Magmatism: New York, Plenum Press, p. 451-495.

Ishizuka, O., Tani, K., Reagan, M.K., Kanayama, K., Umino, S., Harigane, Y., and Dunkley, D.J., 2011, The timescales of subduction initiation and subsequent evolution of an oceanic island arc: Earth and Planetary Science Letters, v. 306, no. 3-4, p. 229-240, doi:10.1016/j.epsl.2011.04.006.

Johnson, L.W., and Tull, J.F., 2002, Sylacauga Marble Group; distal fragment of the Southern Appalachian Cambrian-Ordovician carbonate platform: Southeastern Geology, v. 41, p. 75-102.

Johnson, M.J., 1988, Geology of the gold occurrences near Jackson's Gap, Tallapoosa County, Alabama [M.S. thesis]: Auburn, Alabama, Auburn University, $156 \mathrm{p}$.

Kalbas, J.L., Bream, B.R., Hatcher, R.D., Jr., and Maybin, A.H., III, 2002, Evidence for mafic Ordovician magmatism and Acadian metamorphism in the Brushy Mountains, western Inner Piedmont, of North Carolina: Geological Society of America Abstracts with Programs, v. 34, no. 2, p. 119.

Karabinos, P., Samson, S.D., Hepburn, J.C., and Stoll, H.M., 1998, Taconian orogeny in the New England Appalachians; collision between Laurentia and the Shelburne Falls Arc: Geology, v. 26, p. 215-218, doi:10.1130/0091-7613(1998)026<0215:TOITNE>2.3.CO;2.

Keefer, W.D., 1992, Geology of the Tallahassee synform hinge zone and its relationship to the Brevard zone, Tallapoosa and Elmore Counties, Alabama [M.S. thesis]: Auburn, Alabama, Auburn University, 195 p.

Keep, M., and Haig, D.W., 2010, Deformation and exhumation in Timor: Distinct stages of a young orogeny: Tectonophysics, v. 483 , no. $1-2$, p. 93-111, doi:10.1016/j.tecto.2009.11.018.

Kellberg, J.M., and Grant, L.F., 1956, Coarse conglomerates of the Middle Ordovician in the southern Appalachian Valley: Geological Society of America Bulletin, v. 67, p. 697-716, doi:10.1130/0016-7606(1956)67[697: CCTMOI]2.0.CO;2.

Keller, F.B., 1977, Sandstone turbidites in the Tellico Formation, Indian Creek Embayment, Tennessee, in Ruppel, S.C., and Walker, K.R., eds., The Ecostratigraphy of the Middle Ordovician of the Southern Appalachians (Kentucky, Tennessee, and Virginia) USA: Knoxville, University of Tennessee, Department of Geological Sciences, Studies in Geology 77-1, p. 117-121.

Kemp, A.I.S., Shimura, T., Hawkesworth, C.J., and EIMF, 2007, Linking granulites, silicic magmatism, and crustal growth in arcs: Ion microprobe (zircon) U-Pb ages from the Hidaka metamorphic belt, Japan: Geology, v. 35, p. 807-810, doi:10.1130/G23586A.1.

Kim, H.J., Lee, G.H., Jou, H.T., Cho, H.M., Yoo, H.S., Park, G.T., and Kim, J.S., 2007, Evolution of the eastern margin of Korea: Constraints on the opening of the East Sea (Japan Sea): Tectonophysics, v. 436, no. 1-4, p. 37-55, doi:10.1016/j.tecto.2007.02.014.

Kolata, D.R., Huff, W.D., and Bergström, S.M., 1996, Ordovician K-bentonites of eastern North America: Geological Society of America Special Paper 313, p. $1-84$.

Kolata, D.R., Huff, W.D., and Bergström, S.M., 1998, Nature and regional significance of unconformities associated with the Middle Ordovician Hagan K-bentonite complex in the North American Midcontinent: Geological Society of America Bulletin, v. 110, p. 723-739.

Kunk, M.J., Southworth, S., Aleinikoff, J.N., Naeser, N.D., Naeser, C.W., Merschat, C.E., and Cattanach, B.L., 2006, Preliminary U-Pb, ${ }^{40} \mathrm{Ar}^{-39} \mathrm{Ar}$ and fission-track ages support a long and complex tectonic history in the Western Blue Ridge in North Carolina and Tennessee: Geological Society of America Abstracts with Programs, v. 38, no. 3, p. 66.

Lallemand, S., Heuret, A., and Boutelier, D., 2005, On the relationships between slab dip, back-arc stress, upper plate absolute motion, and crustal nature in subduction zones: Geochemistry Geophysics Geosystems, v. 6, Q09006, doi:10.1029/2005GC000917.

Lamb, D.D., 2001, Geology of the Scaly Mountain quadrangle, emphasizing the structures, timing and emplacement mechanisms for the Rabun granodiorite, eastern Blue Ridge, southwestern North Carolina [M.S. thesis]: Knoxville, University of Tennessee, $86 \mathrm{p}$.

Lamont, W.E., and Hastings, E.L., 1964, Resources and beneficiation studies of copper-bearing pyrite ore, Pyriton, Clay County, Alabama: Alabama Geological Survey Circular 27, 26 p.

Le Maitre, R.W., and International Union of Geological Sciences Working Group, 1989, A Classification of Igneous Rocks and Glossary of Terms: Recommendations of the International Union of Geological Sciences Subcommission on the Systematics of Igneous Rocks: Oxford, UK, Blackwell, 193 p.
Mack, G.H., 1985, Provenance of the Middle Ordovician Blount Clastic wedge, Georgia and Tennessee: Geology, v. 13, p. 299, doi:10.1130/0091 -7613(1985) 13<299:POTMOB >2.0.CO;2.

McClellan, E.A., and Miller, C.F., 2000, Ordovician age confirmed for the Hillabee Greenstone, Talladega belt, southernmost Appalachians: Geological Society of America Abstracts with Programs, v. 32, no. 2, p. 61.

McClellan, E.A., Steltenpohl, M.G., Thomas, C., Miller, C.F., and Hanley, T.B., 2005, Isotopic age constraints and metamorphic history of the Talladega Belt; new evidence for timing of arc magmatism and terrane emplacement along the southern Laurentian margin, in Steltenpohl, M.G., ed., Southernmost Appalachian Terranes, Alabama and Georgia: Southeastern Section Field Trip Guidebook of the Geological Society of America, v. 42, p. $19-50$.

McClellan, E.A., Steltenpohl, M.G., Thomas, C., and Miller, C.F., 2007, Isotopic age constraints and metamorphic history of the Talladega Belt; new evidence for timing of arc magmatism and terrane emplacement along the southern Laurentian margin: The Journal of Geology, v. 115, p. 541-561, doi:10.1086/519777.

McConnell, K.I., 1980, Origin and correlation of the Pumpkinvine Creek Formation: A new unit in the Piedmont of northern Georgia: Georgia Geologic Survey Information Circular 51, $19 \mathrm{p}$.

Mac Niocaill, C., Van der Pluijm, B.A., and Van der Voo, R., 1997, Ordovician paleogeography and the evolution of the Iapetus ocean: Geology, v. 25, no. 2, p. 159-162, doi:10.1130/0091-7613(1997)025<0159:OPATEO>2.3.CO;2.

McConnell, K.I., and Abrams, C.E., 1984, Geology of the Greater Atlanta Region (USA): Georgia Geological Survey Bulletin 96, 127 p.

McConnell, K.I., and Costello, J.O., 1982, Relationship between Talladega belt rocks and Ocoee Supergroup rocks near Cartersville, Georgia, in Bearce, D.N., Black, W.W., Kish, S.A., and Tull, J.F., eds., Tectonic Studies in the Talladega and Carolina Slate Belts, Southern Appalachian Orogen: Geological Society of America Special Paper 191, p. 19-30.

Merschat, A.J., 2009, Assembling the Blue Ridge and Inner Piedmont: Insights into the nature and timing of terrane accretion in the southern Appalachian orogen from geologic mapping, stratigraphy, kinematic analysis, petrology, geochemistry, and modern geochronology [Ph.D. dissertation]: Knoxville, Tennessee, University of Tennessee, p. 455.

Merschat, A.J., Hatcher, R.D., Jr., Bream, B.R., Miller, C.F., Byars, H.E., Gatewood, M.P., and Wooden, J.L., 2010, Detrital zircon geochronology and provenance of southern Appalachian Blue Ridge and Inner Piedmont crystalline terranes, in Tollo, R.P., Bartholomew, M.J., Hibbard, J.P., and Karabinos, P.M., eds., From Rodinia to Pangea: The Lithotectonic Record of the Appalachian Region: Geological Society of America Memoir 206, p. 661-699, doi:10.1130/2010.1206(26).

Meschter-McDowell, S., Miller, C.F., Fullagar, P.D., Bream, B.R., and Mapes, R.W., 2002, The Persimmon Creek Gneiss, eastern Blue Ridge, North Carolina-Georgia; evidence for the missing Taconic Arc?: Southeastern Geology, v. 41, p. 103-117.

Miller, B.V., Fetter, A.H., and Stewart, K.G., 2006, Plutonism in three orogenic pulses, Eastern Blue Ridge Province, southern Appalachians: Geological Society of America Bulletin, v. 118, p. 171-184, doi:10.1130/B25580.1.

Miller, C.F., Hatcher, R.D., Jr., Harrison, T.M., Coath, C.D., and Gorisch, E.B., 1998, Cryptic crustal events elucidated through zone imaging and ion microprobe studies of zircon, southern Appalachian Blue Ridge, North Carolina-Georgia: Geology, v. 26, no. 5, p. 419-422, doi:10.1130/0091 -7613(1998)026<0419:CCEETZ>2.3.CO;2.

Miller, C.F., Hatcher, R.D., Jr., Ayers, J.C., Coath, C.D., and Harrison, T.M., 2000, Age and zircon inheritance of eastern Blue Ridge plutons, southwestern North Carolina and northeastern Georgia, with implications for magma history and evolution of the southern Appalachian orogen: American Journal of Science, v. 300, no. 2, p. 142, doi:10.2475/ajs.300.2.142.

Miller, R.B., and Paterson, S.R., 1994, The transition from magmatic to hightemperature solid-state deformation: Implications from the Mount Stuart batholith, Washington: Journal of Structural Geology, v. 16, no. 6, p. 853865, doi:10.1016/0191-8141(94)90150-3.

Min, K., Renne, P.R., and Huff, W.D., 2001, ${ }^{40} \mathrm{Ar} /{ }^{39} \mathrm{Ar}$ dating of Ordovician K-bentonites in Laurentia and Baltoscandia: Earth and Planetary Science Letters, v. 185, p. 121-134, doi:10.1016/S0012-821X(00)00365-4.

Moecher, D.P., Samson, S.D., and Miller, C.F., 2004, Precise time and conditions of peak Taconian granulite facies metamorphism in the Southern Appalachian orogen, USA, with implications for zircon behavior during crustal melting events: The Journal of Geology, v. 112, no. 3, p. 289-304, doi: $10.1086 / 382760$. 
Moecher, D.P., Massey, M.A., and Tracy, R.J., 2005, Timing and pattern of metamorphism in the western and central Blue Ridge, TN and NC: Status and outstanding problems, in Hatcher, R.D., Jr., and Merschat, A.J., eds., Blue Ridge Geology Geotraverse East of the Great Smoky Mountains National Park, Western North Carolina: Chapel Hill, North Carolina Geological Survey, Carolina Geological Society 2005 Field Trip Guidebook, p. 57-66.

Moecher, D., Hietpas, J., Samson, S., and Chakraborty, S., 2011, Insights into southern Appalachian tectonics from ages of detrital monazite and zircon in modern alluvium: Geosphere, v. 7, no. 2, p. 494-512, doi:10.1130/ GES00615.1.

Moore, W.B., Tull, J.F., and Allison, D.T., 1987, Intrusive chronology, progressive deformation and geochemistry of granitic dikes, and strain analysis of xenoliths, northern Piedmont, Tallapoosa County, Alabama, in Drummond, M.S., and Green, N.L., eds., Granites of Alabama: Tuscaloosa, Alabama, Geological Survey of Alabama, p. 17-31.

Muangnoicharoen, N., 1975, The geology and structure of a portion of the northern Piedmont, east-central Alabama [M.S. thesis]: Tuscaloosa, Alabama, University of Alabama, $74 \mathrm{p}$.

Neathery, T.L., 1968, Talc and Anthophyllite Deposits in Tallapoosa and Chambers Counties, Alabama: Geological Survey of Alabama Bulletin 90, 98 p.

Neathery, T.L., 1973, Observations on the lithologic relationships within the Talladega Group, Alabama, in Carrington, T.J., ed., Talladega Metamorphic Front: Alabama Geological Society, 11th Annual Field Trip Guidebook, p. 51-55.

Neathery, T.L., 1975, Rock unit in the high-rank belt of the northern Alabama Piedmont, in Neathery, T.L., and Tull, J.F., eds., Geologic Profiles of the Northern Alabama Piedmont: Alabama Geological Society Guidebook, 13th Annual Field Trip Guide, p. 9-47.

Neathery, T.L., and Hollister, V.F., 1984, Volcanogenic sulfide deposits in the southernmost Appalachians: Economic Geology and the Bulletin of the Society of Economic Geologists, v. 79, p. 1540-1560, doi:10.2113/ gsecongeo.79.7.1540.

Neathery, T.L., and Reynolds, J.W., 1973, Stratigraphy and metamorphism of the Wedowee Group, a reconnaissance: American Journal of Science, v. 273, p. 723-741, doi:10.2475/ajs.273.8.723.

Neilson, M.J., 1983, Structure and stratigraphy of the Dadeville Group within the Tallassee synform, Tallapoosa County, Alabama: Geological Society of America Abstracts with Programs, v. 15, no. 2, p. 110.

Neilson, M.J., and Stow, S.H., 1986, Geology and geochemistry of the mafic and ultramafic intrusive rocks, Dadeville belt, Alabama: Geological Society of America Bulletin, v. 97, p. 296-304, doi:10.1130/0016 -7606(1986)97<296:GAGOTM>2.0.CO;2.

Nelson, A.E., and Gillon, K.A., 1985, Stratigraphic nomenclature in the Richard Russell and Helen thrust sheets, North Georgia, in Contributions to Stratigraphy 1984: U.S. Geological Survey Bulletin, v. 1605-A, p. A59-A62.

Nowell, G., Kempton, P., Noble, S., Fitton, J., Mahoney, J., and Taylor, R., 1998, High-precision $\mathrm{Hf}$ isotopic measurements of MORB and OIB by thermal ionization mass-spectrometry: Insights into the depleted mantle: Chemical Geology, v. 149, doi:10.1016/S0009-2541(98)00036-9, p. 211-233.

O'Halloran, G.J., and Cas, R.A.F., 1995, Evidence for syndepositional deformation from the Late Devonian of the Mansfield Basin, east-central Victoria: Australian Journal of Earth Sciences, v. 42, p. 581-596, doi:10.1080/08120099508728227.

Ohmoto, H., and Skinner, B.J., eds., 1983, The Kuroko and Related Volcanogenic Massive Sulfide Deposits: Economic Geology Monograph 5, 604 p.

Osborne, W.E., Szabo, M.W., Neathery, T.L., and Copeland, C.W., Jr., compilers, 1988, Geologic Map of Alabama, Northeast Sheet: Alabama Geological Survey Special Map 220, scale 1:250,000.

Patchett, P.J., and Ruiz, J., 1989, Nd isotopes and the origin of Grenville-age rocks in Texas: Implications for Proterozoic evolution of the United States mid-continent region: The Journal of Geology, v. 97, no. 6, p. 685-695, doi: $10.1086 / 629352$.

Patchett, P., Vervoort, J., Soderland, U., and Salters, V., 2004, Lu-Hf and Sm-Nd isotopic systematics in chondrites and their constraints on the Lu-Hf properties of the Earth: Earth and Planetary Science Letters, v. 222, p. 29-41, doi:10.1016/j.eps1.2004.02.030.

Pearce, J.A., and Norry, M.J., 1979, Petrogenetic implications of Ti, Zr, Y, and $\mathrm{Nb}$ variations in volcanic rocks: Contributions to Mineralogy and Petrology, v. 69, p. 33-47, doi:10.1007/BF00375192.

Pearce, J.A., Harris, N.B.W., and Tindle, A.G., 1984, Trace element discrimination diagrams for the tectonic interpretation of granitic rocks: Journal of Petrology, v. 25, no. 4, p. 956-983, doi:10.1093/petrology/25.4.956.
Piercey, S.J., Murphy, D.C., Mortensen, J.K., and Paradis, S., 2001, Boninitic magmatism in a continental margin setting, Yukon-Tanana terrane, southeastern Yukon, Canada: Geology, v. 29, no. 8, p. 731-734, doi:10.1130/0091-7613(2001)029<0731:BMIACM>2.0.CO;2.

Prouty, W.F., 1923, Geology and Mineral Resources of Clay County with Special Reference to the Graphite Industry: Alabama Geological Survey Special Report, v. 12, 190 p.

Quinlan, G.M., and Beaumont, C., 1984, Appalachian thrusting, lithospheric flexure, and the Paleozoic stratigraphy of the eastern interior of North America: Canadian Journal of Earth Sciences, v. 21, no. 9, p. 973-996, doi:10.1139/e84-103.

Rasmussen, B., Fletcher, I.R., and McNaughton, N.J., 2001, Dating lowgrade metamorphic events by SHRIMP U-Pb analysis of monazite in shales: Geology, v. 29, no. 10, p. 963-966, doi:10.1130/0091-7613 (2001)029<0963:DLGMEB >2.0.CO;2.

Raymond, D.E., Osborne, W.E., Copeland, C.W., and Neathery, T.L., 1988, Alabama Stratigraphy: Tuscaloosa, Geological Survey of Alabama Circular 140, $97 \mathrm{p}$.

Raymond, L.A., Yurkovitch, S.P., and McKinney, M., 1989, Block-in-matrix structures in the North Carolina Blue Ridge belt and their significance for the tectonic history of the southern Appalachian orogen, in Horton, H.W., Jr., and Rast, N., eds., Mélanges and Olistostromes of the U.S. Appalachians: Geological Society of America Special Paper 228, p. 195-215.

Robinson, P., and Hall, L.M., 1980, Tectonic synthesis of southern New England, in Wones, D.R., ed., International Geological Correlation Project, Proceedings, Project 27: The Caledonides in the U.S.A.: Blacksburg, Virginia Polytechnic Institute and State University, Department of Geological Sciences, Memoir 2, p. 73-82.

Rogers, J.J.W., and Ragland, P.C., 1977, Distinction between continentalmargin and island arc volcanic suites in metamorphosed and weathered terranes: Geological Society of America Abstracts with Programs, v. 9, no. 2, p. 179-180.

Roser, B.P., and Korsch, R.J., 1986, Determination of tectonic setting of sandstone-mudstone suites using $\mathrm{SiO}_{2}$ content and $\mathrm{K}_{2} \mathrm{O} / \mathrm{Na}_{2} \mathrm{O}$ ratios: The Journal of Geology, v. 94, p. 635-650, doi:10.1086/629071.

Roser, B.P., and Korsch, R.J., 1988, Provenance signatures of sandstone-mudstone suites determined using discriminant function analysis of major element data: Chemical Geology, v. 67, p. 119-139, doi:10.1016/0009-2541(88)90010-1.

Rowley, D.B., and Kidd, W.S.F., 1981, Stratigraphic relationships and detrital composition of the medial Ordovician flysch of western New England; implications for the tectonic evolution of the Taconic Orogeny: The Journal of Geology, v. 89, p. 199-218, doi:10.1086/628580.

Russell, G.S., 1978, U-Pb, Rb-Sr, and K-Ar isotopic studies bearing on the tectonic development of the southernmost Appalachian Orogen, Alabama [Ph.D. thesis]: Tallahassee, Florida State University, 197 p.

Samson, S.D., Patchett, P.J., Roddick, J.C., and Parrish, R.R., 1989, Origin and tectonic setting of Ordovician bentonites in North America: Isotopic and age constraints: Geological Society of America Bulletin, v. 101, p. 11751181, doi: 10.1130/0016-7606(1989)101<1175:OATSOO > 2.3.CO;2.

Sdrolias, M., and Müller, R.D., 2006, Controls on back-arc basin formation: Geochemistry Geophysics Geosystems, v. 7, Q04016, doi:10.1029/2005GC001090.

Seal, T.L., and Kish, S.A., 1990, The geology of the Dadeville complex of the western Georgia and eastern Alabama Inner Piedmont: Initial petrographic, geochemical, and geochronological results, in Steltenpohl, M.G., Neilson, M.J., and Kish, S.A., eds., Geology of the Southernmost Inner Piedmont Terrane, Alabama and Southwest Georgia: Tuscaloosa, Alabama, Geological Society of America, Southeastern Section Meeting, Field Trip Guidebook, p. 65-77.

Sears, J.W., Cook, R.B., Jr., and Brown, D.E., 1981, Tectonic evolution of the Pine Mountain Window and adjacent Inner Piedmont province, in Sean, J.W., ed., Contrasts in Tectonic Style between the Inner Piedmont Terrane and the Pine Mountain Window: Alabama Geological Society Guidebook 18, p. 1-13.

Settles, D.J., 2002, Defining the Hayesville-Soque River and Allatoona faults and an Ordovician arc assemblage within the central Blue Ridge northwest of Dahlonega, Georgia [Ph.D. thesis]: Knoxville, Tennessee, University of Tennessee at Knoxville, $161 \mathrm{p}$.

Shanmugam, G., and Lash, G.G., 1982, Analogous tectonic evolution of the Ordovician foredeeps, southern and central Appalachians: Geology, v. 10, p. 562-566, doi:10.1130/0091-7613(1982)10<562:ATEOTO>2.0.CO;2.

Shanmugam, G., and Walker, K.R., 1978, Tectonic significance of distal turbidites in the Middle Ordovician Blockhouse and lower Sevier Formations in east Tennessee: American Journal of Science v. 278, p. 551-578. 
Shanmugam, G., and Walker, K.R., 1980, Sedimentation, subsidence, and evolution of a foredeep basin in the Middle Ordovician, southern Appalachians: American Journal of Science, v. 280, p. 479-496.

Shervais, J.W., 1982, Ti-V plots and the petrogenesis of modern and ophiolitic lavas: Earth and Planetary Science Letters, v. 59, p. 101-118, doi:10.1016/0012-821X(82)90120-0.

Smith, V.J. and Tull, J.F., 2014, Tectonic evolution of the Wedowee and Emuckfaw Groups of the southern Blue Ridge of east central Alabama: Geological Society of America Abstracts with Programs, v. 46, no. 6, p. 155.

Spell, T.L., and Norrell, G.T., 1990, The Ropes Creek assemblage; petrology, geochemistry, and tectonic setting of an ophiolitic thrust sheet in the southern Appalachians: American Journal of Science, v. 290, p. 811-842, doi:10.2475/ajs.290.7.811.

Stanley, R.S., and Ratcliffe, N.M., 1983, Simplified lithotectonic synthesis of pre-Silurian rocks in western New England: Vermont Geological Survey Special Bulletin, v. 5, no. 12, 9 p.

Stanley, R.S., and Ratcliffe, N.M., 1985, Tectonic synthesis of the Taconian Orogeny in western New England: Geological Society of America Bulletin, v. 96, p. 1227-1250, doi:10.1130/0016-7606(1985)96<1227: TSOTTO $>2.0 . \mathrm{CO} ; 2$.

Steltenpohl, M.G., 2005, An introduction to the terranes of the southernmost Appalachians of Alabama and Georgia, in Steltenpohl, M.G., ed., Southernmost Appalachian Terranes, Alabama and Georgia: Southeastern Section Field Trip Guidebook of the Geological Society of America, v. 42, p. 1-18.

Steltenpohl, M.G., and Kunk, M.J., 1993, ${ }^{40} \mathrm{Ar} /{ }^{39} \mathrm{Ar}$ thermochronology and Alleghanian development of the southernmost Appalachian Piedmont, Alabama and Georgia: Geological Society of America Bulletin, v. 105 , no. 6, p. 819-833, doi:10.1130/0016-7606(1993)105<0819: AATAAD $>2.3 . \mathrm{CO} ; 2$.

Steltenpohl, M.G., Guthrie, G.M., and Cook, R.B., 1990, Geology of the Brevard Zone at Jacksons Gap, Alabama, in Steltenpohl, M.G., ed., Southernmost Appalachian Terranes, Alabama and Georgia: Southeastern Section Field Trip Guidebook of the Geological Society of America, v. 42, p. 101-109.

Steltenpohl, M.G., Heatherington, A., Mueller, P.M., and Miller, R.V., 2005, New isotopic dates on crystalline rocks from Alabama and Georgia, in Steltenpohl, M.G., ed., Southernmost Appalachian Terranes, Alabama and Georgia: Southeastern Section Field Trip Guidebook of the Geological Society of America, v. 42, p. 51-69.

Steltenpohl, M.G., Hatcher, R.D., Jr., Mueller, P.A., Heatherington, A.L., and Wooden, J.L., 2010, Geologic history of the Pine Mountain window, Alabama and Georgia: Insights from a new geologic map and $\mathrm{U}-\mathrm{Pb}$ isotopic dates, in Tollo, R.P., Bartholomew, M.J., Hibbard, J.P., and Karabinos, P.M., eds., From Rodinia to Pangea: The Lithotectonic Record of the Appalachian Region: Geological Society of America Memoir 206, p. 837-857, doi:10.1130/2010.1206(32).

Steltenpohl, M.G., Higgins, M.W., and Crawford, R.F., 2011, The Dog River window, Alabama and Georgia: A first-order structure in the southern Appalachian orogen: Geological Society of America Abstracts with Programs, v. 43 , no. 2 , p. 15 .

Steltenpohl, M.G., Schwartz, J.J., and Miller, B.V., 2013, Late to post-Appalachian strain partitioning and extension in the Blue Ridge of Alabama and Georgia: Geosphere, v. 9, p. 647-666, doi:10.1130/GES00738.1.

Sterling, W.J., 2006, Geology of the southernmost exposure of the Brevard Zone in the Red Hill Quadrangle, Alabama [M.S. thesis]: Auburn, Alabama, Auburn University, $118 \mathrm{p}$.

Stern, R.J., Stratford, W.R., and Salmon, M.L., 2006, Subduction evolution and mantle dynamics at a continental margin: Central North Island, New Zealand: Reviews of Geophysics, v. 44, RG4002, doi:10.1029/2005RG000171.

Stow, S.H., and Tull, J.F., 1982, Geology and geochemistry of the strata-bound sulfide deposits of the Pyriton District, Alabama: Economic Geology and the Bulletin of the Society of Economic Geologists, v. 77, p. 322-334, doi:10.2113/gsecongeo.77.2.322.

Stow, S.H., Neilson, M.J., and Neathery, T.L., 1984, Petrography, geochemistry, and tectonic significance of the amphibolites of the Alabama Piedmont; mafic and ultramafic rocks of the Appalachian Orogen: American Journal of Science, v. 284, p. 414-436, doi:10.2475/ajs.284.4-5.414.

Sutley, D.E., 1977, A petrographic and paleoenvironmental study of the Jemison Chert, Chilton County, Alabama [M.S. thesis]: Tuscaloosa, Alabama, University of Alabama, 64 p.

Sun, S.S., and McDonough, W.F., 1989, Chemical and isotopic systematics of oceanic basalts: Implications for mantle composition and processes, in
Saunders, A.D., and Norry, M.J., eds., Magmatism in Ocean Basins: Geological Society, London, Special Publication 42, p. 313-345.

Swanson, S.E., Raymond, L.E., Warner, R.D., Ryan, J.G., Yurkovich, S.P., and Peterson, V.L., 2005, Petrotectonics of mafic and ultramafic rocks in Blue Ridge terranes of western North Carolina and northern Georgia: Guidebook for the Annual Field Trip of the Carolina Geological Society, p. 73-90.

Taylor, B., and Karner, G.D., 1983, On the evolution of marginal basins: Reviews of Geophysics and Space Physics, v. 21, no. 8, p. 1727-1741, doi:10.1029/RG021i008p01727.

Telle, W.R., Tull, J.F., and Russell, C.W., 1979, Tectonic significance of the bouldery facies of the Lay Dam Formation, Talladega slate belt, Chilton County, Alabama: Geological Society of America Abstracts with Programs, v. 11, p. 215.

Thomas, C.W., 2001, Origins of mafic-ultramafic complexes of the eastern Blue Ridge province, southern Appalachians: Geochronological and geochemical constraints [Ph.D. thesis]: Nashville, Tennessee, Vanderbilt University, $154 \mathrm{p}$.

Thomas, W.A., 1991, The Appalachian-Ouachita rifted margin of southeastern North America: Geological Society of America Bulletin, v. 103, p. 415431, doi:10.1130/0016-7606(1991)103<0415:TAORMO>2.3.CO;2.

Thomas, W.A., Tull, J., Bearce, D.N., Russell, G., and Odom, L.A., 1980, Geologic synthesis of the southernmost Appalachians, Alabama and Georgia: The Caledonides in the U.S.A.: Blacksburg, Virginia Polytechnic Institute, Department of Geological Sciences, Memoir 2, p. 91-97.

Tracy, R.J., Rye, D.M., Hewitt, D.A., and Schiffries, C.M., 1983, Petrologic and stable-isotopic studies of fluid-rock interactions, south-central Connecticut: I. The role of infiltration in producing reaction assemblages in impure marbles: American Journal of Science, v. 283-A, p. 589-616.

Trupe, C.H., Stewart, K.G., Adams, M.G., Waters, C.L., Miller, B.V., and Hewitt, L.K., 2003, The Burnsville fault: Evidence for the timing and kinematics of southern Appalachian Acadian dextral transform tectonics: Geological Society of America Bulletin, v. 115, no. 11, p. 1365-1376, doi:10.1130/B25256.1.

Tull, J.F., 1978, Structural development of the Alabama Piedmont northwest of the Brevard Zone: American Journal of Science, v. 278, p. 442-460, doi:10.2475/ajs.278.4.442.

Tull, J.F., 1985, Stratigraphy of the Sylacauga Marble Group, in Tull, J.F., Bearce, D.N., and Guthrie, G.M., eds., Early Evolution of the Appalachian Miogeocline: Upper Precambrian-Lower Paleozoic Stratigraphy of the Talladega Slate Belt: Alabama Geological Society, 22nd Annual Field Trip Guidebook, p. 1-26.

Tull, J.F., 1998, Analysis of a regional middle Paleozoic unconformity along the distal southeastern Laurentian margin, southernmost Appalachians: Implications for tectonic evolution: Geological Society of America Bulletin, v. 110, p. 1149-1162, doi:10.1130/0016-7606(1998)110<1149: AOARMP $>2.3 . \mathrm{CO} ; 2$.

Tull, J.F., 2002, Southeast margin of the middle Paleozoic shelf, southwesternmost Appalachians: Regional stability bracketed by Acadian and Alleghanian tectonism: Geological Society of America Bulletin, v. 114, no. 6, p. 643-655, doi:10.1130/0016-7606(2002)114<0643:SMOTMP>2.0.CO;2.

Tull, J.F., 2011, Significance of late extensional faults in the southwestern Appalachian eastern Blue Ridge: Geological Society of America Abstracts with Programs, v. 43, no. 2, p. 15.

Tull, J.F., and Barineau, C.I., 2012, Overview of the stratigraphic and structural evolution of the Talladega slate belt, Alabama Appalachians, in Eppes, M.C., and Bartholomew, M.J., eds., From the Blue Ridge to the Coastal Plain: Field Excursions in the Southeastern United States: Geological Society of America Field Guide 29, p. 263-302, doi:10.1130/2012.0029(08).

Tull, J.F., and Barineau, C.I., 2014, Alternative tectonic model for the development of the southern Appalachian Blountian foreland clastic wedge: Geological Society of America Abstracts with Programs, v. 46, no. 3, p. 36.

Tull, J.F., and Campbell, K.H., 2012, Structurally lower contact of the Emuckfaw Group and the Alexander City fault issue, in Barineau, C.I., and Tull, J.F., eds., The Talladega Slate Belt and Eastern Blue Ridge: Laurentian Plate Passive Margin to Back-Arc Basin Tectonics in the Southern Appalachian Orogen: Tuscaloosa, Alabama Geological Society, 49th Annual Field Trip Guidebook, p. 27-37.

Tull, J.F., and Holm, C.S., 2005, Structural evolution of a major Appalachian salient-recess junction; consequences of oblique collisional convergence across a continental margin transform fault: Geological Society of America Bulletin, v. 117, p. 482-499, doi:10.1130/B25578.1. 
Tull, J.F., and Stow, S.H., 1980, The Hillabee Greenstone: A mafic volcanic complex in the Appalachian Piedmont of Alabama: Geological Society of America Bulletin, v. 91, no. 1, p. 27-36, doi:10.1130/0016-7606 (1980) $91<27$ :THGAMV>2.0.CO;2.

Tull, J.F., and Stow, S.H., 1982, Geologic setting of the Hillabee metavolcanic complex and associated stratabound sulfide deposits in the Appalachian Piedmont of Alabama: Economic Geology and the Bulletin of the Society of Economic Geologists, v. 77, p. 312-321, doi:10.2113/gsecongeo.77.2.312.

Tull, J.F., and Telle, W.R., 1989, Tectonic setting of olistostromal units and associated rocks in the Talladega slate belt, Alabama Appalachians, in Horton, J.W., Jr., and Rast, N., eds., Mélanges and Olistostromes of the U.S. Appalachians: Geological Society of America Special Paper 228, p. 247-269, doi:10.1130/SPE228-p247.

Tull, J.F., Moore, W.B., Drummond, M.S., and Allison, D.T., 1985, Contrasting fault systems in the Appalachian Piedmont of Alabama: Geological Society of America Abstracts with Programs, v. 17, p. 139.

Tull, J.F., Harris, A.G., Repetzki, J.E., McKinney, F.K., Garrett, C.B., and Bearce, D.N., 1988, New paleontologic evidence constraining the age and paleotectonic setting of the Talladega slate belt, southern Appalachians: Geological Society of America Bulletin, v. 100, p. 1291-1299, doi:10.1130/0016-7606(1988)100<1291:NPECTA >2.3.CO;2.

Tull, J.F., Ragland, P.C., and Durham, R.B., 1998, Geologic, geochemical, and tectonic setting of felsic metavolcanic rocks along the Alabama recess, southern Appalachian Blue Ridge: Southeastern Geology, v. 38, p. 39-64.

Tull, J.F., Barineau, C.I., Mueller, P.M., and Wooden, J.L., 2007, Volcanic arc emplacement onto the southernmost Appalachian Laurentian shelf: Characteristics and constraints: Geological Society of America Bulletin, v. 119, no. 3-4, p. 261-274, doi:10.1130/B25998.1.

Tull, J.F., Mueller, P.A., Barineau, C.I., and Wooden, J.L., 2009, Age and tectonic implications of the Elkahatchee quartz diorite, eastern Blue Ridge Province, Southern Appalachians, USA: Geological Society of America Abstracts with Programs, v. 41, p. 288.

Tull, J.F., Allison, D.T., Whiting, S.E., and John, N., 2010, Southern Appalachian outer Laurentian margin initial drift-facies (Chilhowee Groupequivalent) sequences: Implications for margin evolution, in Tollo, R.P., Bartholomew, M.J., Hibbard, J.P., and Karabinos, P.M., eds., From Rodinia to Pangea: Geological Society of America Memoir 206, p. 935956, doi:10.1130/2010.1206(36).

Tull, J.F., Barineau, C.I., and Holm-Denoma, C.S., 2012, Characteristics, Extent, and Tectonic Significance of a Middle Ordovician Back-Arc Basin in the Southern Appalachian Blue Ridge: Tuscaloosa, Alabama Geological Society, 49th Annual Field Trip Guidebook, p. 12-26.

Tull, J.F., Holm-Denoma, C.S., and Barineau, C.I., 2014, Early to Middle Ordovician back-arc basin in the southern Appalachian Blue Ridge: Characteristics, extent, and tectonic significance: Geological Society of America Bulletin, v. 126, p. 990-1015, doi:10.1130/B30967.1. van Staal, C.R., Whalen, J.B., McNicoll, V.J., Pehrsson, S., Lissenberg, C.J., Zagorevski, A., van Breemen, O., and Jenner, G.A., 2007, The Notre Dame arc and the Taconic orogeny in Newfoundland, in Hatcher, R.D., Jr., Carlson, M.P., McBride, J.H., and Martínez Catalán, J.R., eds., 4-D Framework of Continental Crust: Geological Society of America Memoir 200, p. 511-552, doi:10.1130/2007.1200(26).

Vincent, H.R., McConnell, K.I., and Perley, P.C., 1990, Geology of Selected Mafic and Ultramafic Rocks of Georgia: A Review: Georgia Department of Natural Resources, Environmental Protection Division, Georgia Geologic Survey, Information Circular 82, 59 p.

Waldron, J.W.F., and van Staal, C.R., 2001, Taconian Orogeny and the accretion of the Dashwoods Block: A peri-Laurentian microcontinent in the Iapetus Ocean: Geology, v. 29, p. 811-814, doi:10.1130/0091-7613 (2001)029<0811:TOATAO >2.0.CO;2.

Wharton, M.R., Hathway, B., and Colley, H., 1995, Volcanism associated with extension in an Oligocene-Miocene arc, southwestern Viti Levu, Fiji, in Smellie, J.L., ed., Volcanism Associated with Extension at Consuming Plate Margins: Geological Society, London, Special Publication 81, p. $95-114$.

White, W.W., 2008, Geology of the 1:24,000 Tallassee, Alabama, Quadrangle and its implications for southern Appalachian tectonics [M.S. thesis]: Auburn, Alabama, Auburn University, 89 p.

Wielchowsky, C.C., 1983, The geology of the Brevard zone and adjacent terranes in Alabama [Ph.D. dissertation]: Rice University, Houston, Texas, $237 \mathrm{p}$.

Woodall, J., and Barineau, C.I., 2010, Strain analysis of the basal contact of the Lay Dam Formation, Talladega Belt, Alabama: Geological Society of America Abstracts with Programs, v. 42, no. 1, p. 93.

Yanagihara, G.M., 1994, Structure, stratigraphy, and metamorphism of a part of the Columbus Promontory, Western Inner Piedmont, North Carolina [M.S. thesis]: Knoxville, Tennessee, University of Tennessee, 214 p.

Yardley, B.W.D., 2009, The role of water in the evolution of the continental crust: Journal of the Geological Society, London, v. 166, p. 585-600, doi:10.1144/0016-76492008-101.

Yoon, S.H., Sohn, Y.K., and Chough, S.K., 2014, Tectonic, sedimentary, and volcanic evolution of a back-arc basin in the East Sea (Sea of Japan): Marine Geology, v. 352, p. 70-88, doi:10.1016/j.margeo.2014.03.004.

Zagorevski, A., Rogers, N., van Staal, C.R., McNicoll, V., Lissenberg, C.J., and Valverde-Vaquero, P., 2006, Lower to Middle Ordovician evolution of peri-Laurentian arc and backarc complexes in Iapetus; constraints from the Annieopsquotch accretionary tract, central Newfoundland: Geological Society of America Bulletin, v. 118, p. 324-342, doi:10.1130/B25775.1.

Manuscript AccePted by the Society 6 December 2014 